UC-NRLF

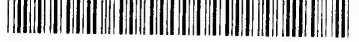

B 3 492 175

.

6res 


\section{CAMDEN MISCELLANY}

\section{VOL. XII}

CAMDEN THIRD SERIES

V O L. X V I I I

UI ISIR L
OF THE

UNIVERSITY

of

CALIFORMIA

L O N D O N

OFFICES OF THE SOCIETY

$6 \& 7$ SOUTH SQUARE

GRAY'S IN N

I 9 IO 
GENERAE

PETT? TCALA 


\section{CONTENTS}

TWO LONDON CHRONICLES, FROM THE COLLECTIONS

of John Stow. Edited by C. L. Kingsford, M.A., F.S.A., F.R.Hist.S.

LIFE OF SIR JOHN DIGBY (1605-1645). Edited bY Georges Bernard, L.Ès-L. . . . . . 6 I

ITER BELlicosum: AdAm Wheeler his Account of 1685. Edited by H. E. Malden, M.A., Hon. Fellow of Trinity Hall, Cambridge, V.-P. and Hon. Sec. R. Hist.S.

COMMON RIGHTS AT COTTENHAM AND STRETHAM IN CAMBRIDGESHIRE. EDITED BY W. Cunningham, D.D., F.B.A., President of the Royal Historical Society and Archdeacon of Ely . 


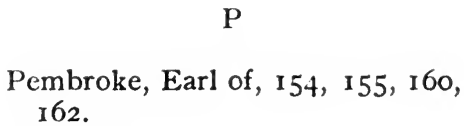

Philips Norton, 1 55, 165 .

Prisoners, list of, $16_{3}, 164$.

\section{$\mathrm{S}$}

Salisbury, I54, 159 .

Sedgemoor, 162.

Shepton Mallet, I54, I61, I62.

Summerton, 162.

\section{$\mathrm{T}$}

Talbot, Major, 165.

Taunton, I 54 .

Trowbridge, 160 .
Wells, 165.

Westbury, I6I.

Weston Church, 163, r64.

Weston Moor, I62, I64, 165 .

Weston Zoyland, 155, I62.

Wheeler, Adam, I53, I62, I63, $165,166$.

Wilton, 154, I60.

Wyndham, Colonel, I53, 156, I6r, $162,163,165$.

Wyndham, Lord, 153.

\section{Y}

Yong, Colonel, I6r. 


\section{OMMON R I GH T S A T COTTENHAM $\mathscr{O}$ STRETHAM IN CAMBRIDGESHIRE}


- 


\section{COMMON RIGHTS A T \\ COTTENHAM \& STRETHAM IN CAMBRIDGESHIRE}

EDITED FOR THE ROYAL HISTORICAL SOCIETY

B Y

W. CUNNINGHAM, D.D., F.B.A.

President of the Royal Historical Society

and Arcbdeacon of Ely

CAMDEN MISCELLANY

V O L. X I I

LONDON

OFFICES OF THE SOCIETY

6 छ 7 SOUTH SQUARE

GRAY'S I N N

1910 
Digitized by the Internet Archive in 2007 with funding from

Microsoft Corporation 


\section{CONTENTS}

\section{COTTEN HA M}

\section{Preface}

Articles of Agreement 1596

. . . . 193

Orders made 12 Jan. 1639 . . . . . . . . . . 230

Extract from the decision in regard to Subtraction of tithe (I630) . $\quad 246$

An account of the Tithing of cattle (1820) . . . . . 250

\section{ST RETHA M}

Extracts from a Decree in the Court of Exchequer (I607) . . 253

A coppie of an Affoedavit, 25 Maij 1609. . . . . . 260

Orders made for Stretham by Commissioners, 28 June 1609 . 26I

Orders made for Thetford by Commissioners, 28 June 1609. . 263

Orders made by the Leet, 29 April I6I4 . . . . . 265

Orders made by the Court Leet, 29 April I6I4 . . . . 267

Orders made by the Inhabitants of Stretham, 24 Feb. 1622. . 275

Libell for Tithe of Herbage . . . . . . . . . 288

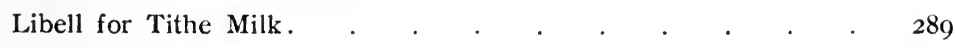

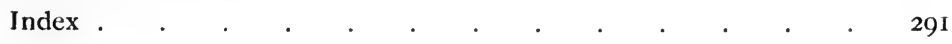




\section{P R E F A C E}

The papers here printed furnish materials which are of considerable assistance for the study of one great department of English rural life. During the Middle Ages the management of land was collective, as it was carried on by the co-operation of the lord and the various tenants within the manor. So far as tillage is concerned, we are fairly informed, as we can picture to ourselves the open fields with their intermingled strips, and know from the surveys of many manors the precise obligations in week-work and boon work which the villeins were bound to render, and the amount of free time which they had for their own holdings. But the information we possess about the management of the common waste is apt to be scrappy and incidental. It must have been a matter of supreme importance in every manor, as the inhabitants were always dependent on the waste for the pasturing of the stock with which they worked their land; and they might rely on it for building materials and fuel as well. In those districts where, from the conditions of climate and soil, cattle feeding and dairy farming were specially remunerative, the good management of the resources of the common waste must have been a far more important factor in the prosperity of a township than the tillage of the common fields. Much of the land on the south west of the fens, which lies along the valleys of the Cam and the Ouse, between Cambridge and Ely, was peculiarly adapted for pasturage and was of no use for tillage. Here the collective management of the common waste survived in a fashion, which is interesting as a matter of local history, while it is still more important as an illustration of a system which was once generally prevalent and has now died out. 
In modern times enclosure has been carried on by act of parliament, and the parish has generally been the unit dealt with ; but before the eighteenth century this was not usually the case. There were instances of ruthless enclosure when a whole parish was depopulated and the land used entirely as sheep-run $;^{1}$ but occasional incidents of this kind, which made a deep impression on the minds of contemporaries, such as John Ross and Sir Thomas More, can hardly be taken as typical. Throughout England generally, enclosure was a process which went on piecemeal within one parish after another, and it was a constant cause of irritation from the manner in which it interfered with customary rights. Sometimes a few contiguous strips in the common fields might be enclosed, either by the Lord, or by a tenant with his permission, to be tilled in severalty ; in such a case the ground was withdrawn from the area over which cattle pastured in winter, and was to this extent lost to the community. Besides this, the lord might encroach on the common waste by applying more and more of it for use in severalty, so that the opportunities of the tenants for pasturing their stock were seriously interfered with. The grievance from the increase of sheep farming evidently took this form in some cases where there was no evidence of deliberate depopulating. Both Cottenham and Stretham afford cases in point, and there is a chorus of complaint on this matter during the sixteenth century. It is plain too, from such writers as Fitzherbert, Hales, Tusser, and Norden, that farming in severalty was generally regarded as the system by which the most was made of the land. As this improvement was adopted there was a tendency for the common waste to diminish not only in area but in importance, so far as the lord and his more progressive tenants were concerned; the neglected waste was sometimes given over to an undesirable class of squatters. ${ }^{2}$

1 Cunningham Growth of English Industry and Commerce, I, 404, 448, 529.

- See my Growth of English Industry, II. 570. A bill was introduced in 1656 which provided for the regulation of commons and commonable grounds, but it failed to pass. E. M. Leonard, Royal Hist. Soc. Trans. XIX, I3o. 
The Tudor enclosures seem to have affected Cambridgeshire but little. Wholesale depopulation does not appear to have occurred to any great extent, though there had been complaint on this score against Barnwell Abbey in 1414, on the ground that 'great waste of housing ' had been made at Chesterton, and that no housing was left standing on the manor "but if it were a Shepe Cote or a berne or a swynsty and a few houses by side to putt in bestes." I Sir John Cutts' depopulation at Childerley is a later instance of a similar kind, though he may have aimed at creating a park for deer, rather than a sheep-walk; but throughout the high lands of Cambridge generally, there was little temptation to enclose the common fields. The colleges at Cambridge offered a convenient market for food stuffs, both corn and dairy produce ${ }^{2}$; and as landowners they were interested in having plentiful supplies. The corn rent act which "passed the houses before they were sensible of the good consequences of it," ${ }^{3}$ was apparently intended to enable the colleges to obtain supplies on reasonable terms, though it also served to maintain their revenues, as the value of money fell. There was less motive in this district than in other places to engage in sheep farming in the sixteenth century; and agricultural improvement went on in the seventeenth and eighteenth centuries without the breaking up of the common fields. In the southern part of Cambridge the enclosure of common fields was delayed ; and we have, as a consequence, unusually full records of the actual changes which ensued when it at length took place.

In the Isle of Ely, the conditions were entirely different : whereas in the high land every part of a parish was fit for use as arable land-and in the case of some parishes, e.g. Hildershamwas actually so used, the land in the Isle of Ely, which was fit

1 Rot Part. IV. 6o. b.

2 Vancouver. General View, pp. 193-198. W. Gooch. General Viene of the County of Cambridge (1813), pp. 56-94.

318 El. c. 6. Compare Kennett, Parochial Antiquities, II 295.

4 Vancouver. General View of the Agriculture in the County of Cambridgc, (I794), p. 87. 
for tillage, consisted of occasional islets and ridges in a great area of country, much of which was flooded in winter and could only be used for pasturage in summer. The work of draining the fens, which served as common pasturage for the men of one village or for several villages together, was pushed on in the seventeenth century ; and as it proceeded, large areas were allotted in severalty to the Duke of Bedford and other undertakers. ${ }^{1}$ The direct interests of the Bedford family were chiefly in the valley of the Nene, and the Russells became a dominating influence there. Somewhat similar conditions prevailed in the parishes, such as Cottenham, Stretham, Waterbreach, Willingham and Haddenham, which lie near the junction of the Ouse and the Cam ${ }^{2}$ except that this district was in much ${ }^{3}$ less need of drainage, at all events for purposes of pasture farming, than the rest of the fens. The undertakers and wealthy improvers had not such a footing that they could carry everything before them ; the owners of common rights were able to hold their own, and they continued to pasture the herd of milch-kine on the common waste.

In this district we find several instances of legal proceedings with the view of limiting the lord of the manor's power of interference and of defining and securing common rights over the waste; ${ }^{4}$ and the records of these recurring disputes give very full information about many details of life in a district where dairy farming was the main avocation. But there were also frequent differences

${ }^{1}$ For the areas of enclosed and unenclosed land in different parishes see Vancouver op. cit. 193.

2 On the old course of this river see Vancouver op. cit. 29 also my paper in Camb. Antiq. Soc. Communication XIV, 75 .

${ }^{3}$ Badeslade Lyun p. $29 \mathrm{R}$. Atkins has interesting allusions to pasture farming in several instances : he notes that "there be usually 3 heards of milch cattel at Soham, each consisting of 700 beasts, as Jefferie the host of the Bull informed me, yet is there in this Towne in winter Scarcitie of Butter and cheese, and not so mutch as will suffice the Towne." Harl. MS. 501 I f. 21 b.

${ }^{4}$ An interesting parallel from a similar district in Lincolnshire is afforded by the agreement at Epworth in 1359, printed by W. Peck. Topographical Account of the Isle of Axholme. Ap. i. 
between manorial lords and the tenants, and among the latter there were some substantial men who were not alarmed at the cost of legal proceedings. Taverner writing in 1653 remarks of Haddenham that "many of the inhabitants had competent estates, who wanting a full imployment in tillage, they of ancient custom make it a part of their recreation to discourse of law cases." 1 The frequency of such legal proceedings in this district has been the occasion for putting on record a mass of details that would otherwise have been likely to pass out of mind altogether. When a difference of opinion arose between the lord and the tenants the usual course appears to have been to submit the matter to arbitration, and then to obtain a decree in Chancery which might make the award binding on the successors of those who signed the agreement ; or the difficulties might be settled by a commission from the Court of Exchequer. Every decision which enabled either the lord or any of the tenants to hold more land in severalty was a permanent step in the progress of enclosure ; but this was not the only matter in dispute, as difficulties arose about the levying of tithe, and gave occasion to acrimonious litigation.

Very full information has been preserved in regard to affairs at Cottenham, and it is possible to trace the course of the successive disputes which arose; the story goes back to the Tudor period when sheep farming was the most profitable use to which pasturage could be put. Sir Francis Hinde of Madingley, the lord of the manors of Lyles and Crowland and of the moiety of the manor of Sames in Cottenham, came to an agreement with the "greatest number of welthiest and substancyalist inhabitants and tenants of Cottenham in the behalfe of themselves and of all the rest of the inhabitants of the said town," at Easter 1580; he and his tenants were to enjoy sheep-walk for 2000 sheep in severalty,

1 They failed in their attempt to establish common rights over the Delfs and Ouse-delfs, an area of about 800 acres which had been kept as severalty and let for grazing by the Bishop of Ely from the time of Edward III. F. Taverner. $A$ Vindication of the Furie who upon the twelfth day of May 1653 gave their verdict in the Upper Bench at Westminster against the inhabitants of Hadenham, pp. 18-22. 
while he gave up his right of joisting ${ }^{1}$ sheep or cattle on the common fields of the parish, and allowed the tenants to pasture the town flock and to fold their sheep on these fields. Chancery proceedings were taken in 1584, and Edward Coke argued on behalf of George Pepys and others of the same family that this agreement was a very onesided affair; that the lord and the principal farmers were encroaching on the common rights and had not left sufficient pasturage for the poorer inhabitants, and that the right of joisting cattle on the town fields, which the Lord had given up was much more limited, and therefore of less value than he alleged. The dispute was not settled by the arbitration which took place in 1583, when the Dean of Ely, the Master of St John's, the Master of Christ's and other eminent men were called in to adjudicate. Subsequently, in 1585, a Chancery decree, enforcing an award by the Bishop of Peterborough, seems to have set the matter at rest for the time. Unfortunately the record of his decision appears to have been lost, so that it is difficult to get at the result of the case, in regard to which the Bill of Sir F. Hinde, the Answers of the Pepys family, and the Replication of Sir F. Hinde have been preserved."

When the disputed pasture rights at Cottenham came into court again in 1596, the whole situation seems to have changed, for there is no mention of the Lord's sheep walk, or of the town flock, but the resources of the place were evidently being devoted to the herd of milch-kine. The same families were again the principal parties in the dispute. Sir William Hinde of Madingley, the son of Sir Francis, exhibited a bill in Chancery, and an answer was made by Pepys. The matter was referred to Lord North, the Lord Lieutenant and Custos Rotulorum of the County, who "upon hearing of the matter in variante hath sette down certain articles of agreement with their mutual consents." ${ }^{3}$ This award, unlike its

1 To joist or agist cattle is to allow the owners, in return for a payment, to feed them on common pastures.

2 Record office, Chancery Proceedings, Elizabeth H. $\frac{16}{5} \frac{6}{8}$.

3 Decree in Chancery in 1669. 
predecessors, stood the test of time : for the Articles of Agreement then drawn up were confirmed by a Decree in Chancery ${ }^{1}$ and continued to be the basis on which the management of the common waste at Cottenlam rested, until the enclosure in 1842 .

We have a contemporary reference to this agreement in a description of the Fens by Richard Atkins of Outwell in 1604; and as he was according to Dugdale "a person "whose observations on these fenny grounds were very notable, " it may be worth while to print his description at length. ${ }^{3}$

Cottenham. Lord there Sr. William Hynd. It hath verie good Fennes and great; viz from a Fenne by Awdrich causey called Sechell to Chittering on the East. The names of Cottenham fennes be thes.

1. Sechell right over against Outlawes Cote, it begynneth at the gate by the River on the west and cometh downe to Robbins lode.

2. Michellee about 200 acres lieth est of Sechell, Robins lode parting Michellee and Sechell on the one syde.

3. Topham more about 150 acres lyeth more Est Michellee towards denney.

4. Awbrose is about $\frac{3}{4}$ of a mile square it butteth on michellee on the north and the field to the south, and vppon smethy fenne to the west. Memorandum, the Lottes there about 200 acres wherin everie howse hath an acre. It lyeth north Est from Awbrose.

5. Smethy fenne is that wherto they passeover a bridg. It containeth 500 acres and more. It contynueth from Cottenham to the were at the howse next Aldrith Calsey.

6. Charefenne common Fenne, and a pece called xx. $d$. lie more Est to denney Ward, the Common is a turfe fenne 20 . leadeth to the Riv $^{r}$ and is aboute 30 acres, Charefenne is next denney and ther goeth the heard commonly.

On the Est side of the Towne next denny, the Lord hath taken in certeine pastures called Woolfes pastures, by reason wherof he

1 9. May I597. Mr. Bacon was counsel in this suit.

2 Embanking. 378.

3 The MS. is among Dugdale's Collections in the British Museum: Harl. MSS. 5oII f. 23, 3. It has been summarised by Badeslade: Navigalion of King's Lynn. 74 . 
doth not Common but is excluded by composition, some say this is for his life onely. The Fenns of Cottenham be at least 4 miles long Est and West, and about a mile di. broad or more one place with an other, and have the River of Owse all the way on the North. They be all imbancked and provision made to convey there water away, more then any Fenne towne theraboute, yet be the banckes in many places defective, in so much as Charefen lyeth [waste] and long drowned and overfloweth into Chitteringes. Note that in Awbrose Fenne, ther is a pece of high ground about 200 acres, it hath a pece adioyning to it called Cuttes lying betwene yt and Topham more. Memorandum, a pece of an 100 acres of Common for which the Towne gave $\mathrm{S}^{\mathrm{r}}$ William Hynde 200ti. Item the Calves pasture there aboute 20 acres nere to the Cote in Stretham called the white house, there is a were called poole were 16 foote deepe etc., and below the same within a stones cast there is a grave[1] layd by Stretham men to cart ther foder ${ }^{1}$ out of willow fenne, where the water commeth not above 2 foot deepe, a great cause of drowning those Fenns.

Some sixty years later the dispute broke out again; Sir William Hincle had disposed of his rights at Cottenham to Hobson, the Cambridge carrier; he died in 1630 , and the representatives of this family endeavoured to set the award of 1596 aside. Katharine, the widow of 'Thomas Hobson (the carrier's grandson) and her son, denied that the commoners in Cottenham had any right of common whatsoever within the marshes, fens or waste grounds of Cottenham. As a result of the litigation which ensued, a decree was issued from Chancery in 1669 confirming once more the award which had been made by Lord North, and establishing the position which had been maintained by the owners of common right.

Beside the conflict with the manorial lords there were other legal proceedings which throw additional light on the economic and social conditions of Cottenham. The Rectory was a valuable piece of preferment, especially after Lord North's award had come into effect; and the claims of the clergy in regard to tithes, especially in regard to small tithes, were frequently resisted. A certain Walter Male had subtracted tithes of apples and of hay in

1 Compare Sir Clement Edmunds, Report on Badeslade. op. cit. p. 30. 
the years 1623, 1624 and 1625 when Dr. Leonard Maw was rector, and was sued in the ecclesiastical court by his executors, ${ }^{1}$ with the result that the Vicar General decreed that he should pay $6 d$. for the tithe of apples in each of the years 1623 and 1624 and $2 d$. for the tithe of apples in 1625 , as well as $24 / 5 \frac{1}{2}$ for the tithe of hay in the same years. The schedule of tithable things which was annexed to this decision serves to shew that the fruit-growing, for which Cottenham is now famous, is a thing of long standing: damsons and plums seem to have been produced as well as pears and apples.

An embittered dispute arose as soon as the puritans came into power. Dr. Richard Manby, who had been presented to the living by the Bishop, was a decided high churchman of the school of Laud; he soon became the subject of high handed proceedings, as the parliamentary committee deprived him of his living in 1641 ; and Mr. French, who had married Robina the daughter of Cromwell, entered on the enjoyment of the preferment. The rector retired to a living of which he was patron in Yorkshire, leaving Mrs. Manby and the children to live with his sister Mrs. Cass ; Mrs. Cass had a "little house in Cottenham which gave her a right to the Common, but having no cattle to put upon it, the Doctor bought some cows for her to keep a dairy, the better to support herself and his own family; ${ }^{2}$ but the barbarous villains presently drove the cows from the common to the market, where they sold them and put the money into their own pockets." 3

At the Restoration Dr. Manby still survived and re-entered on the enjoyment of the emoluments of his benefice, but it was only by legal process that he was able to eject $\mathrm{Mr}$. Nye, an intruder

1 A similar action was brought against Henry Graves.

${ }^{2}$ Mrs Cass was apparently treated as guilty of colouring Dr. Manby's cows (article XXXIII), and the cows may have been sold to pay the fine. See also article XXIX.

${ }^{3} \mathrm{~J}$. Walker : Sufferings of the Clergy. 304. Compare also Brit. Mus. Add. Mss. I5670, f. II 7, 149 
who had succeeded $\mathrm{Mr}$. French, and who practically secured another year's income by his tenacity.

As the work of drainage proceeded, and land which had formerly been used for pasturage came to be employed for tillage, the question of tithe again became the subject of litigation.

In 1780 the tenants of Soame Jenyns, who owned the undertakers land in Cottenham, took a crop of oats, and Dr. Ward, the Rector claimed the tithe, though this was in excess of the tithe allowed in Lord North's award. ${ }^{1}$ His attempt in $1811^{2}$ to set the award aside altogether was unsuccessful; and when the claim to the tithe of crops on the Undertakers piece was brought into court by the next rector, Dr. Sparke, it was disallowed in 1821. The award of 1596 proved to be the corner stone of village economy both in regard to manorial and ecclesiastical claims.

The story of the maintenance of common right by legal procedure has in some ways less interest than belongs to the Orders which remain in the parish chest at Cottenham with regard to the manner in which the common rights should be exercised. The lords had had days of drift, when they took account of all the cattle, and saw that no persons, who could not claim common rights, fed their cattle on the waste. The risks of infection and damage were reduced by insisting that the cattle should be properly sorted out, and rules were laid down as to the times at which they might feed in different parts of the common waste.

In the seventeenth century this practice survived at Stretham where the orders were issued in the court leet, though powers were given to the commoners of Stretham and Thetford respectively to make by-laws for their separate cow-pastures. ${ }^{3}$ But the case of

1 dricle XXVI and schedule.

2 The only record of this dispute which I have seen among the papers in the parish chest is a draft of the pleadings in the Rector's favour in 1810 .

3 Vancouver, writing in 1794, commends the Stretham Fen Reeves for their attention to drainage, (Op. Cil. 150). Further details of the working of a similar system are to be found at Willingham where the account; of the Fen Reeves during several years in the reign of Elizabeth have been preserved. Compare also the sustom of Whittlesea. W. Nelson, Lex Maneriormm, Ap. 79. 
Cottenham is of special interest: it may be that the owners of common right felt especial need of effective administration so that the banks which protected the fens might be kept in good condition, but they bargained to take the whole matter into their own hands. The responsibility for the management of the herd and the waste was transferred to twenty four order makers chosen according to specified proportions from among the copyholders in the various manors. This system of government was maintained with success till the parish was enclosed in 1842 and the kine could no longer be pastured as a common herd; but a tradition still lingers of the picturesque procession which was formed at milking time by the herd of two thousand kine which moved from the fen, past the church, and along the village street with each cow turning into her own byre as it was reached.

The machinery for managing the common waste at Cottenham, which was introduced in 1596, is of interest in its constitutional aspect, as it furnishes an instance of a democratically governed township successfully carried on for two hundred and fifty years. The system has interesting analogies with the townships which were springing up on the Borders as the country became more peaceable, and in the colonies which were soon to be planted in Ulster and in New England. The owners of common right at Cottenham formed a village community which had become free by the buying out of the manorial rights : and this type of social organisation had a great future before it. The circumstances of the New England settlers gave the opportunity for the reproduction of similar institutions for the regulation of economic affairs. The system in vogue in Massachusetts, at Chelsea in 1638, ${ }^{1}$ at Malden in $1678,{ }^{2}$ or at Lexington ${ }^{3}$ was closely allied to that which existed at Cottenham in 1596, and the township, in a new atmosphere and in new surroundings came to play an important part in the constitutional and political history of the United States.

1 M. Chamberlain, History of Chelsea, I, 89.

2 D. P. Covey, History of Malden, $35^{2}$.

3 C. Hudson, History of the town of Lexington, 33, 63. 
Though the story of Cottenham possesses a unique interest, it does not stand alone, as analagous difficulties in regard to pasture rights arose in several of the neighbouring parishes, at one time or another; still the proceedings in each case had special characteristics. The course of events at Stretham was so closely parallel as to be very instructive : the inhabitants of Stretham and of Thetford intercommoned to some extent, and there had been long controversies and diverse suits between Sir Miles Sandys lord of the manor of Stretham and his tenants. In 1597 Sir Miles Sandys was the complainant; but on June 221607 the Court of Exchequer on the complaint of the Lord of the Manor of Thetford, the Rector of Stretham and other tenants, granted a commission ; and an award was made on the adjudication of Francis Tyndall, Henry Bynge and John Batisforde. The scheme of these commissioners was that of granting Sir Miles Sandys 100 acres out of Stretham Fen, of bringing the intercommoning of the Stretham and Thetford herds to an end, and of excluding Sir Miles from interference of any kind in an area of 1600 acres of fen. Occasion was taken at the same time to secure the copyholders from arbitrary exactions : heriots were abolished and the fines were to become certain, but it is remarkable that even at this late date the obligation of the copyholders to give personal service in ploughing and reaping was reinforced.

The orders which were made immediately in consequence of this decree have not been preserved. They gave rise to complaint, which was exhibited to the Court of Exchequer on 25 May 1609. as the requirements of the tenants for pasturing the stock with which they worked the land had not been allowed for sufficiently, and a new set of orders were issued by the commissioners on June 28 1609. Subsequent orders and bye-laws were made in 1614 and 1622. The question of tithe was also a cause of dispute at Stretham, and the libels which have been preserved are instructive as showing the manner in which the tithe was claimed in regard to pasturage and to milk.

At Willingham the same Sir Miles Sandys, who had entered on 
the estate by grant from the crown dated 8 Nov. 1601 on a payment of 62069 , came to a similar agreement with the tenantry, after they had "unlawfully, ryotously, routeously and in forcible manner" pulled down the fence of an enclosure. In accordance with the award of the Bishop of Ely, Sir John Cotton, Anthony Page, Mark Steward and Francis Tyndall, it was agreed that Sir Miles should be allowed to enclose, but that he must leave a sufficient way for 'a great herd of cattle in the same place where formerly the way hath been for the drift of cattle,' and that he was not to have any rights of feeding cattle on the common pasture. It was agreed to have this award confirmed by a decree in Chancery at the joint expense of the two parties, but this does not seem to have been carried out. At Willingham also Sir Miles abandoned some of his claims over the copyholders, and in 1611 remitted the hen rent, egg rent, days works and heriots to which they had been liable.

Similar action was taken at a later date at Waterbeach : an agreement had been come to between Peter Standly, Lord of the Manor of Waterbeach cum Denny in 1740 and this was confirmed immediately afterwards by act of parliament. The Lord of the Manor gave up his right to joyst cattle in consideration of a payment of $2 /$ - each from the commoners; the rights of each commoner as to the number of horses, sheep, cows \&c., which he might pasture were defined, and arrangements were made for the election of Fen Reeves. ${ }^{1}$ An amending act was passed in 1790 ; and an admirable picture of Waterbeach in the last decade of the eighteenth century, with its activities in the way of pasture farming and market gardening, was put on record by the Rev. Robert Masters who had been Vicar of the parish. ${ }^{2}$

A large number of papers bearing on the management of common pasture are preserved in the parish chests at Cottenham

1 An act passed in the fourteenth year of his late Majesty, George II, entitled "An Act for the effectual draining of Waterbeach Land."

2 A Short account of the parish of Waterbeach in the Diocese of Ely by a late Vicar. 1795 . 
and Stretham, and in the Public Hall at Willingham, and through the kindness of the Rev. R. P. Moline, Rector of Cottenham, of the Rev. S. S. Stitt of Stretham, and of Mr. Few of Willingham, I have had opportunities of examining them; but it has not been altogether easy to make a selection of the documents which are likely to be of most interest to members of the society. There could be no doubt, of course, about printing Lord North's award, and the articles of agreement on which the whole authority of the Cottenham order maker was based. The orders for 1639 are the oldest which survive, and these are printed ; they were reissued annually with insignificant alterations and copies exist for 1645,1662 and 1665. The schedule of tithe owing by Walter Male at Cottenham is also given in full.

Extracts have been made from the decree of the Court of Exchequer which enforced the award of the commissioners at Stretham. The orders and bye laws at Stretham are so varied, that they are given in full, as well as the complaint of 1609 and the papers in regard to tithe.

The members of the Society are much indebted to Mr. Arthur Bull, Church Warden at Cottenham, for making transcripts of the papers in his charge and for his careful notes upon them; to the Rev. Evelyn Young of Fen Drayton for discharging a similar task at Stretham, and to Mr. Hubert Hall for the additional information which had been preserved in the Record office.

\section{THE COTTENHAM ARTICLES OF AGREEMENT}

There are four manuscript copies and one printed copy of the articles of agreement in the parish church at Cottenham, but so far as is known the original document no longer exists.

In the Chancery decree "It was ordered that the complainants should at the Defendant's request deliver the defendants a copy of the said Articles... and should also suffer the defendants to examine such copy with the original articles, which copy... etc."

It does not appear that this original document was ever pro- 
duced in any of the various law trials that have taken place from time to time.

The copies from which these "Articles" have now been printed may be described as follows-

I. The parchment copy.

On the inside page of the outer cover are these entries-viz.

"Nov. 25. 1735. I bought this copy of W. Hayhow of Ely, who had it among a parcell of old parchments of $\mathrm{Mr}$. Barnes, whose ancestors had an estate there and are in the list of the first contractors in the agreement." and-

"July 1870. Mr. Wyles of Denney Abbey gave this copy to me to place in the parish Chest.

Samuel Banks.

Rector of Cottenham."

At the foot of this copy is written

"Scriptum per me Rich d Robinson apud villam [de C......] quarto die Aprilis et anno $\mathrm{D}^{\mathrm{n} 1} 1615 . "$

II. The paper copy. (1638).

This has at the foot-

"Written by mee John Clarke in the yeare of our Lord God one thousand six hundredth and thirtie eight."

There are several notes in seventeenth century handwriting on a spare sheet at the end of the book, as follows-

(A) "The Officers have two bookes of these orders fairlie writ, one in parchment of fifteen leaves 'the other in paper of twelve leaves."

(B) The Decretall Order.

"IX die Maii Anno Regni Elizabethe Regine XXXIX. Inter Willelmum Hynde et alios querentes, Georginam Pepes et alios defendentes.

1 This is not the same as the existing parchment copy which consists of ten leaves. 
Forasmuch as the matter in question betweene the said parties hath been by all their mutuall assents referred unto the hearing and ending of the said right honorable the Lord North one of her Maties most honorble privie Counsell and Treasurer of her Highnesse houshold, according to agreement heretofore made betweene the said parties. Which agreement was, that if anie ambiguitie did arise on ether side touching the premises then he to have the determining thereof. Who upon hearing the said matter in variante hath set downe certen Articles of Agreement with their like mutuall assents. Whereunto as well the plaintiffs as defendants have subscribed their names as verie well content there unto. And humblie desired by Mr. Bacon, being of their Councell, that the same may be by this Court decreed accordingly. It is therefore ordered and decreed by the right honorableSr. Thomas Egerton Knight Lord Keeper of the Great Seale of England with the assent of all the said parties on both sides That all and everie such matter Thing Clause and Article as is set downe between the said parties by the said Lord North in the said Agreement shall be perfurmed fulfilled and kept by all and everie of the said parties whose names are to the said Agreement subscribed according to the tenor and true meaning of the same in ample and forcible manner as if the said Agreement had been judiciallie pronounced and set downe by this Court."

\section{Li. A. fol. 897.}

This copie was taken out of the Registrie. Termino Michrelis Anno regni regis Caroli 17 Anno domini 1641. (paying for it $2 s .6 \mathrm{~d}$. that is XVIII ${ }^{\mathrm{d}}$. the first folio and $X I^{\mathrm{d}}$. the next.

(C) "Decretum inter Hynde et Pepys.

The inhabitants subscribers to these articles are 111. towards the latter end of them is the Master of St. Johns but not his name which makes me doubt it is not a true copie of the subscription or subscribers. Amongst whom is not the parson of Cottenham, or Dr. Fleming. But in the beginning of them the inhabitants parties to these articles are about 60 . 
So it seems all of them subscribed not. Neither is the Master of St. Johns name in the begining of the decree. The inhabitants parties to the decree are 98 and defendants 4 in all 102. So more are made parties to the articles than are to the decree which makes me thinke it a counterfeet copie."

(D) "I conceive the parsonage of Cottenham to be improved by the Composition.

1. The inclosures granted to the parson by the same is worth EXXX per an.

2. The benefit of keeping 20 milch cows upon the common Ex per an.

3. His Easter booke improved by poundes per an.

4. Tithe corn improved £LX per an."

"This is a copie of the note was given me by Jo. Wright."

(E) "Dr. Fleming was Instituted into Cottenham vndecimo aprilis 1581.

Robert Telnie quinto Februarie 1601."

III. A copy of the Articles of Agreement is inserted in the Decree in Chancery-probably from the paper copy.

IV. About the time of the last law trial, concerning matters more or less connected with these "Articles," (circa 1820.), the articles were printed. A few copies of this (incorrect) edition exist : and also what is most likely the written copy made for the printing of the book.

The first two of the above mentioned copies have been carefully collated for this edition of the "Articles of Agreement."

\section{STRETHAM PAPERS}

The Rector of Stretham, in the Isle of Ely, has in his custody a number of papers of the 16 th and 17 th centuries, relating for the most part to the tithes and common-lands of that place and of the Chapelry of Thetford, and to a long succession of disputes and law suits arising therefrom, covering the greater part of the 17 th century. 
Amongst these various papers is a thin paper book, endorsed on the cover as follows :

\section{"Stretham 1623}

Copies of several ancient Documents relating to the Rectory of Stretham and the Byelaws for regulating the Commons: including a Terrier of the Lands belonging to the Parsonage in 1571."

The book, measuring about 11 by $6 \frac{1}{2}$ inches, is stitched in a cover of thin parchment. It had originally 80 pages, numbered; 8 of these pages have been removed, having been apparently blank. On the last page is a table of contents, which is here reproduced; the items marked with an asterisk are those which are now printed in whole or in part.

"A table of the cheif things contained in this Booke.

* The Decree of the Exchequer in 1607 relating to the Mannor of Stretham.

A Terrier of the glebe of Stretham Parsonage. [12 Nov. 1571.]

* Orders made 1622.

* Orders made 1614.

A note of the Seuerall fens in Stretham. [1626.]

A coppie of Wisbeach Barton Lease. [1538.]

A terrier of mecldow and marrish in Stretham. [1614.]

* Orders made 1609.

* A coppie of an Affœdauit.

* A Coppie or Proesident of a Libell for Herbage of Steers for tythe milke.

An Inuentarie of Euidencies beelonging to Stretham. [1573.]

1 The numbers are those of the pages in the MS. book. 
There is no doubt that these copies were made for the use of the Rev. Nicholas Felton; about half of the book is in his own handwriting. He was the eldest son of Nicholas Felton, Bishop of Ely, who presented him to the Rectory of Stretham, to which he was inducted 10 March $162 \frac{1}{2}$. It is stated in Carter's "History of Cambridgeshire" that he was ejected by Manchester's warrant dated 19 March 1644 . There are two other copies of the Decree of the Court of Exchequer, one of them being a certified copy, with which the copy here printed has been carefully collated.

Considerable interest appeared to be aroused among the members of the Royal Historical Society who were present when I alluded to the contents of these papers at the last Annual Meeting, (R. Hist. Soc. Trans. Third Series, IV. 12) and I am glad that an opportunity has so soon arisen of putting them in type.

Trin : Coll : Cambridge.

W. C.

Dec. 1910. 


$$
\text { - }
$$




\title{
ARTICLES OF AGREEMENT
}

\author{
MADE AND FINISHED THE
}

TWENTITH DAYE OF NOVEMBER IN THE NYNE AND THIRTITH YEARE OF THE REIGNE OF OUR SOVREIGNE LADY ELIZABETH BY THE GRACE OF GOD OF ENGLAND FRAUNCE AND

\author{
IRELAND QUEENE DEFENDER \\ OF THE FAI'TH छ'c.
}

\section{T A B U LA}

Article

I. That Mr. Hinde shall have and enjoy in severalty the great Inclosures upon Mare-hill.

II. Christ College to have Sixty Acres and one Close belonging to the Manor of Harlstons. . . . . . . [198]

III. The Parson to have his Moor-closes and two Closes in Alborough.

IV. The Heirs of John Peyps, deceased, to enjoy in severalty certain Closes. . . . . . . . . . [199]

V. Christ College to have one Acre next their Close. . . [200]

VI. Richard Scott to enjoy in severalty certain Grounds. . [200]

VII. St. John's College to hold and enjoy their Lands at Stone-ditch. [200]

VIII. The Dean and Chapter of Ely to enjoy Pelham's Cross Close. [200]

IX. The Lords excluded from keeping sheep . . . . [201]

X. Mr. Hinde to have no Sheep, with a proviso for Westwick. [20I]

XI. That Alborough shall be fed and be Common. . . . [202]

XII. No Cattle taken into Jeest, Joist or Adjist. . . . . [203]

XIII. The Holme Closes allowed Twenty Acres. . . . . [203]

XIV. No Houses to be built upon the Common, and those already built to be pulled down. . . . . . . . [204]

$\mathrm{XV}$. The Inhabitants to enjoy the Commons which were Common for Sixty years past. . . . . . . . [204]

XVI. Allowance for Ditches and Banks, \&c. . . . . [205]

XVII The Lords may Plant the Banks with Wood, \&c. . . [206]

XVIII. Officers may levy Penalties and despend the money . . [206]

XIX. For Robert Rivers fourteen Roods in Smithy Fen, \&c. . [207] 
Article

XX. The Town to have the Wood in the Fens. . . . . [207]

XXI. The Inhabitants to have the leavings in Smithy Fen. . . [208]

XXII. How twenty Customary Tenants, Order-makers are to be nominated and chosen. . . . . . . . [ [208]

XXIII. How the sums of Money levied by reason of pains and penalties are to be paid. . . . . . . . [210]

XXIV. Orders are to be wrote and Published within fifteen days after they are made.

XXV. No Orders to be made in any Court. . . . . . [212]

XXVI. No person to Common not being Inhabitants, except . . [213]

XXVII. What Cattle shall be put upon the Common. . . . [215]

XXVIII. For dividing the Lots and Weanling Calves. . . . [215]

XXIX. When and by whom Two Men are to be chosen. . . [216]

XXX. Concerning Cow-way. . . . . . . . . [218]

XXXI. For Common Drain and Tillage. . . . . . [219]

XXXII. When Sheep to go in Smithy Fen . . . . . [219]

XXXIII. For Coloring of Cattle . . . . . . . . [2I9]

XXXIV. Forfeit of Swine. . . . . . . . . . [219]

XXXV. For Bye-Herds. . . . . . . . . . [220]

XXXVI. For appointing Fieldreeves and Officers. . . . . [220]

XXXVII. For Pales and Walls. . . . . . . . . [22I]

XXXVIII. Suits againt Officers, how to be borne . . . . . [222]

XXXIX. About those who willingly break this Agreement. . . [222]

XL. No Benefit to be had till Subscribed. . . . . . [223]

XLI. For Charges of passing this book. . . . . . [223]

XLII. For Droves and Drifts. . . . . . . . . [224]

XLIII. Mr. Hinde to make his drifts. . . . . . . . [224]

XLIV. To consent to Ratify to bring this decree to an Agreement . [224]

XLV. To pay or give security for the $300 £$. to Mr. Hinde. . . [226]

XLVI. King's College Tenants to enjoy the Common as others. . [228]

XLVII. How any mistake which may arise may be rectified. . . [228]

Betweene Willm Hinde of Maddingley in the County of Cambridge Esquire lord of the Manor of Crowland and Lyles and the moyety of the Manor of Sames in Cottenham in the said County of Cambridge on th'one parte, And the Master or Keeper of Christes Colledge in the Universitie of Cambridge and the Fellowes and Schollers of the same Colledge, The Deane of the Cathedral 
Church of the holy and undivided Trinity of Ely and the Chapter of the same place, the Provost of the Kinges Colledge of Blessed Mary of saint Nicholas in Cambridge and the schollers of the same Colledge, The Master of the Colledge of Saint John the Evangelyst in the Universitie of Cambridge [and] the Fellowes and Schollers of the same Colledge, Samuel Flemynge parson of the Rectorie of Cottenham aforesaid, Thomas Allcock gent, John Russell gent, Thomas Pepis the elder, gent, Thomas Pepys the younger, gent, Robert Pepys the elder, gent, George Pepys, gent, Richard Scott, gent, Edward Scott Master of Artes, William Lovell, John Taylor, Thomas Watts, John Pepis, gent, Rob'te Barnard, Frauncys Browne, William Treeve, Richard Whitinge, John Fanne, Thomas Vale, Edward Cambridge, Thomas Badcocke, Thomas Barnes, William Brigges, Richard Brigges, Richard Mayze, Thomas Ryvers the younger, Richard Caverley, Thomas Humphery, Thomas Haddowe, William Fordham, John Brigham the younger, Richard Norman, Henry Gylate, John Ewesden the younger, Nicholas Haylocke, Thomas Roger, William Walker, John Mayle the younger, George Pepys the younger, Thomas Howleton, Richard Townsende, William Webbe, William Phillippes, Robert Fordham, Robert Wimple, William Roger, William Halden, John Brigham the elder, John Ewsden the elder, Thomas Ryvers the elder, Izabell Browne widowe, William Denson, Walter Reeve, John Fletcher, Thomas Jackeson the younger, Anthony Greene, Thomas Wimple, Henry Langham, gent, John Thacksteede, Rob'te Pepis de Norff[olk], Edward Norman, John Essex jun, Elizabeth Norman widowe, Richard Bridgeman, John Reade, John Essex sen, Thomas Jackeson the elder, John Denson, William Lambe, John Glover, Edward Rymer, Edward Reeve, John Haddowe the elder, Thomas Bankes, William Phillippe, John Phillippe, Thomas Hawkyns, Thomas Smyth, Elizabeth Essex, widowe, William Ivatt, Robert Rivers, John Maile sen, James Mayle, Edward Mayle, William Emerson, Thomas Awsten, Clement Cropwell, John Haddowe the younger, Robert Norman, John Norman, William Jackeson als Tabram, John Roger, John Maize, Raphe Mullinex, George 
Huddlestone, gent, Thomas Howlebeame, Jeremy Hubberd, Edward Bleane, William Causbie, William Sanderson, William Collyn, Thomas Whiteheade, George Essex, Rowland Essex, Richard Emerson, Rowland Browne, Robert Bankes, John Banks Master of Arts, William Moulton, Thomas Richmond, Thomas Mayle, Anthony James, John Halden, Edward Halden, Richard Awstene, John Hardingham, Thomas Brigham, William Leache, Johanne Curde widowe, Henry Leache, Robert Mayle, William Howbeame.

\section{ARTICLE I}

Article the First it is agreed, by and between the said parties, for them First, Mr. Hinde shall and every of their heirs and assigns that the said William Hinde, enjoyseveral his heirs and assigns shall enjoy inclosed and in severalty, for ever, Inclosures in all his Inclosures in the Fields, Fens, and Parish of Cottenham respect of the Manor of Crowlands, Lyles and Moiety of Sames.

Longhill Close,part of Lyles. aforesaid which are now inclosed as they be now inclosed hereafter mentioned; that is to say one Close of Ten Acres, commonly called by the name of Long Hill Close, part of the Manor of Lyles in Cottenham aforesaid, and one Little Close thereunto adjoining, conteyning one Acre, be it either more or less, one end thereof abutting upon a parcel of Long Hill. now being common, towards the northeast, and the other end thereof abutting towards the South West, upon a great Close called Marehill and Tillage. Also the said great Close last before mentioned, called Marehill and Tillage, part of the Manor of Crowlands, in Cottenham aforesaid, one end thereof abutting upon the aforesaid Close of Ten Acres towards the North-east, and in part upon the said Common Ground afore mentioned towards the North-east, and the other end thereof abutting towards the South-west, upon a way called Kings's Cross Way, leading from Cottenham aforesaid to Landbeach.

King's-cross Also one other Close called King's-cross-close, part of the said close, part of the Manor of Crowlands. Manor of Crowlands, the one end thereof abutting upon King'scross-way aforesaid towards the North-east, ancl the other end thereof towards the South-west, abutting upon a Close belonging to 
the Moiety of the manor of Sames, late in the tenure of John Pepys, gent., deceased. Also one other Close now in the tenure and occupation of one Henry Annys or his Assigns, parcell of the Mr. Hinde to enjoy a Moiety of the Manor of Sames, in Cottenham aforesaid, now in the tenure of William Hinde, lying on the south-east side of King'scross-close aforesaid and one end thereof abutting upon Kingscross-way before mentioned towards the North-east; and the other end thereof towards the South-west, abutting upon a Close now in the possession of the executors of John Pepys, deceased, part of the Moiety of the said Manor of Sames, late in the tenure of the said John Pepys, deceased. Also, one other Close, called Eastland Close, parcell of the Manor of Lyles, containing by estimation Six Acres, (be it more or less), one end thereof abutting in part upon a Close belonging to the Manor of Burdlaries, alias Harlstons, towards the South-West, and the other end thereof towards the North-east abutting upon a Close parcell of the said Manor of Lyles, called Horsemore Close.

Also one other Close before mentioned, called Horsemore Close, part of the said Manor of Lyles, containing by estimation Ten Horsemore Close, part Acres, (be it more or less), lying between the Dunstall Field on of Lyles. the North-West, and a Close belonging to the Moiety of the Manor of Sames, late in the tenure of the said John Pepys, deceased, and a close belonging to the Manor of the Rectory of Cottenham aforesaid, on the South-east. Also one other Close, being in a field of Cottenham aforesaid called Foxall Field, late in the Tenure of Thomas Halfhead, lying on the North-east side of a Way that leads from a place called Lambs Cross to Histon, and lying on the South-west side of a Close, now in the tenure of Richard Scott or his Assigns. Also one other Close called Kits- Kits'-bush bush Close, part of the said Manor of Crowlands aforesaid lying Close, part next the Way called Cambridge Way, leading from Cottenham lands. towards Histon aforesaid, towards the North-west, and next to a Close belonging to the Manor of Burdlaries alias Harlstons, towards the South-east. And it is agreed, as aforesaid, that the same Closes shall lie and be several unto the said William Hinde, his heirs and 
assigns, for ever, to his and their sole, proper use and behoof : provided always that the Great Inclosure upon Marehill, lying and adjoining unto Crikle Fen, which heretofore was common, and hath been inclosed, and now lieth open and to be enjoyed as Inclosures common again, shall not be said to be any of the said Inclosed to lie as Common to all the Inhabitants. Grounds, but that the said Ground shall be and remain in Common unto all the Inhabitants of the town of Cottenham, their heirs and assigns, for ever having good right of common in the said Fens, wastes and Commonable Grounds in Cottenham aforesaid.

\section{ARTICLE II}

Christ College to enjoy Sixty Acres of certain Inclosures in respect of the Manor of Harlstons.
And it is agreed, as aforesaid, that it shall be lawful for the Master, Fellows, and Scholars of Christ College in Cambridge and their successors, and every of their Farmers, Tenants, and assigns, to hold and enjoy inclosed and in severalty, for ever, all the inclosures and Grounds inclosed, hereafter mentioned; (that is to say) One Close containing by estimation Three Score Acres, (more or less), belonging to the Manor of Burdlaries, alias Harlstons, now in the occupation of Francis Brown, gent, or his assigns, lying on the South-east side of Kits'-bush Close aforesaid, and on the North-west side of the Common Drain that lieth between the bounds of Cottenham aforesaid and the said town of Histon before mentioned. Also one other Close belonging to the Manor of Burdlaries alias Harlstons, one end thereof abutting upon a Close late in the occupation of Anthony Green, gent., belonging to the Manor of Lyles, towards the North-east, and lyeth on the South side of the Dunstall Field aforesaid, and on the North-west side of a Close belonging to the Rectory of Cottenham, now in the occupation of the said John Pepys, gent.

\section{ARTICLE III}

The Parson to enjoy his Moor
Also, it is agreed, that it may and shall be lawful to and for the Parson and Incumbent of the Rectory and Parsonage of Cottenham 
aforesaid, and his Successors, Farmers, or Assigns, to hold and Closes and enjoy in severalty, for ever, the several Inclosures and Grounds in inclosed hereafter mentioned; (that is to say), one Close, late in the Alborough. occupation of John Pepys, gent. deceased, belonging to the Manor of the Rectory of Cottenham aforesaid, one end thereof abutting upon a Close belonging to the Moiety of the Manor of Sames, late of John Pepys, deceased, towards the North-east, and the other end thereof toward the South-west abutting upon a way that leadeth from Cambridge Way to Histon Moor. Also, two other Closes in Alborowe, in the occupation of the said John Pepys, belonging to the Manor of the said Rectory, one end thereof abutting upon the Church Field towards the South-west, and lyeth on the North-west side of a Close, now in the occupation of the executors and Assigns of John Pepys, deceased, being the Freehold of the Heirs, Executors, or Assigns of the said John Pepis.

\section{ARTICLE IV}

Also it is agreed that it shall and may be lawful to and for the The heirs of heirs, executors and assigns of John Pepys, gent., deceased, and their Farmers and assigns, to hold and enjoy in severalty, for ever, the several Inclosures and Grounds inclosed, hereafter mentioned, (that is to say), one Close divided into Five Parts, belonging to the Moiety of the Manor of Sames, late in the tenure of John Pepys, John Pepys, to enjoy certain Inclosures in respect to their Moiety of Sames. deceased, one end of the said Close abutting in part upon the said Close, called King's-Cross Close, towards the North-East, and in part upon the said Close, now in the tenure of Henry Annys, his assign or assigns, towards the North-East, and lying on the Northwest side of Histon Moor and Landbeach Moor. Also two other Closes in Alborowe, now in possession of the Heirs, Executors, or Assigns of John Pepis, deceased, one end of the same Closes abutting upon the Church Field aforesaid towards the South-west and lying the South-west side of a Close belonging to the Manor of the Rectory of Cottenham, now in the occupation of John Pepis, gent. 


\section{ARTICLE V}

Christ Col- Also it is agreed, as asforesaid, that the Master, Fellows, and lege to enjoy Scholars of Christ's College in Cambridge, may inclose and hold in next their severalty, for ever, all that One Acre adjoining to their Close in close and Land. ferne-Field and the Hempland.

\section{ARTICLE VI}

Richard Scott to enjoy certain Grounds.

Also that the said Richard Scott, his Heirs and assigns, may inclose and hold in severalty, for ever, all that One Close at Curds Willows in the said Field, called Dunstall Field; and one broad Land, lying in the Common field of the said town, called Farm Field, abutting upon a way that leadeth from Cottenham aforesaid to Cambridge, towards the South-East ; and One Acre lying in the said Foxall Field, abutting upon Stone Ditch towards the SouthEast ; [and] one Broad Land, adjoining to the said Richard Scott's own house; so that he and they shall leave forth a convenient way leading over the said broad land for all kinds of Passages and Carriages, for ever, within twenty feet where a way is now used.

\section{ARTICLE VII}

St. John's College to inclose Five Acres at Stone Ditch, or elsewhere.

Pelham's Close to be enjoyed by the Dean and Chapter of Ely. exceed not the quantity of Five Acres.

\section{ARTICLE VIII}

Also that the Master, Fellows, and Scholars of St. John's College in Cambridge may Inclose and hold in severalty, for ever, all those their Lands which lie against a place called Stone ditch, or any other of their lands in the said Town of Cottenham, so as they exceed not the quantity of Five Acres.

Also that the close called Pelham's Croft Close shall be enjoyed in severalty by the Dean and Chapter of Ely and their successors and Farmers, without any challenge of any way to be made through the same. 


\section{ARTICLE IX}

And it is further agreed as aforesaid, in consideration of the The Lords Master, Fellows, and Scholars of Christ College in Cambridge, Sheep. their Farmers and assigns, for and in respect of the Demesnes of the Manor of Burdlaries; and the Parson of Cottenham aforesaid and his Successors, Farmers, and Assigns, for and in respect of the Demesnes of the Manor of the Parsonage of Cottenham aforesaid; and the Heirs, Executors, and Assigns of John Pepys, gent, deceased, and their Farmers and Assigns, for and in respect of the Demesnes of the Moiety of the Manor of Sames, shall be hereafter clearly excluded from having any Sheep going or depastured in any of the walks, feedings or places in Cottenham aforesaid other than in their or every of their several Grounds inclosed, any usage or custom heretofore had or used to the contrary, notwithstanding. Except three score Sheep, hereafter mentioned, to be kept by the incumbent of the Parsonage Manor, in manner and form hereafter mentioned.

\section{ARTICLE X}

Also, it is agreed, as afforesaid, that the said Mr. William Hinde, Sheep with his Heirs, Farmers and Assignes, in consideration of the said a proviso for Inclosures by him and them to be held and enjoyed as is aforesaid, shall keep no Sheep within the bounds and limits of Cottenham, aforesaid, without his Pastures inclosed in the Right of the Manors of Lyles and Crowlands, or of his Moiety of the Manor of Sames at any time hereafter, or in the Right that he hath by virtue of a Lease of or in the said manor of Burdlaries, or by any right that Sir Francis Hinde, father of the said William Hinde, heretofore had, or that the said William Hinde, his heirs or assigns, ever had, hath, or may have at any time hereafter to and in the said Manors of Burdlaries, Crowlands, Lyles, and Sames, or any of them, saving always such benefit of Common feeding and pasturing 
of sheep to and for the copyholders of the Manors, and of any of them, as they have heretofore had, to be ordered and used according to the true intent of these presents. Provided always that it shall be lawful for the said William Hinde, his heirs and assigns, to have his and their proper sheep to go or be depastured for and in respect of the Manor of Westwick in the Holme, in time commonable, in and upon Thistly Hill and Little North Fen, unto a place called the Runnels, near the Lands-ends, but not between the Runnels and the Lands-ends, nor elsewhere within the bounds of Cottenham.

What Sheep shall be kept for Westwick; what Sheep go not in the Severals. Also Alborough to be fed as Common.

And, it is agreed, as aforesaid, that there shall be for the Manor of Westwick and the inhabitants there dwelling but one Flock of Sheep kept, wherein both the Sheep of the said William Hinde, his heirs and assigns, and also the Sheep of the said Inhabitants and occupiers of any lands in Westwick in respect of any Common for any Lands in Westwick, shall go and be depastured. And that it shall be lawful for the said inhabitants of or in the Town of Cottenham aforesaid, their heirs and assigns, having Tenements in Cottenham aforesaid whereunto common of or for sheep doth belong, to keep in times commonable their sheep in the said Holme, Thistly Hill, and Little North Fen, and all other places and fields in Cottenham aforesaid except in Grounds which are now several and inclosed, or that hereafter shall be inclosed by virtue of this agreement when they are inclosed, and to erect as many sheep folds as they, or any of them, shall think good, at any time hereafter, within the arable fields of Cottenham, aforesaid.

\section{ARTICLE XI}

Also it is agreed, as aforesaid, that all the Meadow Ground in Cottenham, called Alborowe, shall be fed and lie Common for ever, according as is herein mentioned. And, also that one other piece of Ground or Leys, lying between the said field, called Dunstall Field, and the said close, called Kit's Bush Close, shall lie Common for ever. And also, it is agreed, as aforesaid, that the saicl William 
Hinde, his Heirs, Farmers, and Assigns, shall not at any time hereafter feed or keep or cause to be fed or kept upon the Meadow, called Alborowe, or upon any such grounds as are or shall be appointed by virtue of or according to the true meaning of any article herein mentioned, for the pasture of the herds of Milch Kine or Bullocks within the limits and bounds of Cottenham aforesaid, without his Pastures Inclosed, above the number of fifteen milch kine, at any time hereafter, in the right of the scite of the Manor of Crowlands; nor above the number of fifteen milch kine for his scite of the Manor of Lyles, nor for the scite of his moiety of the Manor of Sames, above six milch kine, and those milch kine to be kept and fed at such times and in such places as the milch kine of most part of the inhabitants of Cottenham aforesaid shall be depastured and kept in Cottenham aforesaid and not otherwise.

\section{ARTICLE XII}

Also it is agreed, as aforesaid, that neither the said William No Cattle to Hinde, his Heirs nor assigns, nor the Master, Fellows and Scholars be taken in of Christ College in Cambridge, nor their successors nor their Adjistment assigns, nor their nor any of their Tenants or Farmers, shall take any manner of cattle to be depastured and fed as by way of joistment or hiring in or upon any grounds within the bounds and limits of Cottenham aforesaid without their several pastures now inclosed, or which by any Article herein mentioned and be agreed to be inclosed by virtue of this agreement.

\section{ARTICLE XIII}

And it is also agreed, as aforesaid, that the said William Hinde, Holme his Heirs and Assigns, nor any of them, shall not inclose or fence in, to keep in severalty, at any time hereafter, any other grounds, within the bounds or limits of Cottenham than is already inclosed, Closes allowed Twenty save only that it shall be lawful for the said William Hinde, his Heirs and Assigns, to inclose twenty acres more than is already 
inclosed, whereof the Leys of his own, abutting on the way leading over the Holme-bridge and upon the Holme corner, shall be part, and the rest shall be likewise of land of his own, or of such as he can purchase adjoining to the said Leys.

\section{ARTICLE XIV}

No Houses to be built upon the Common, and those already built to be pulled down.

And also it is agreed, as aforesaid, that no Houses, Hovels, Sheds, or other like buildings, shall be made by any person or persons at any time hereafter upon any part of the Common Fens or wastes in Cottenham aforesaid, nor in any grounds, by these presents meant to be had or used as or for Common, except one little cottage or shed, which may be erected hereafter for the keeper of the Fen, by the consent of the greater number of the ordermakers hereafter mentioned, and that the houses already builded by Robert Lyon, William Curde, and widow Turner, shall be pulled down before Easter term next, by the Town Officers, or their deputies, which shall have authority there by most of the order-makers hereafter mentioned.

\section{ARTICLE XV}

The Inhabi- Also that the said Inhabitants of Cottenham aforesaid, their tants to use the Commons, which were $\mathrm{Ccm}$ mon for sixty years past, to their best benefit.

Heirs and Assigns, shall have all the profit and use of all the Common Fens and waste grounds and places in Cottenham aforesaid, which have been used for Common all the time of the year within this threescore years last past, except such as be herein mentioned to be kept in severalty or inclosed, and to use them to the best commodity of the said inhabitants, for ever, and in and about them to make banks and ditches as the most part of the ordermakers hereafter mentioned shall think good, and to do what they or the most part of them will or shall think convenient for the bettering of the said Commons, or any part of them, according to such order as shall be made in such manner as shall be hereafter mentioned; saving always to the said William Hinde, his Heirs 
and Assigns, his weifs, Strays, Fellons, goods, and Liberty to Hawk, Hunt and Fowl, not excluding the Inhabitants from fowling there. Provided always, that the said William Hinde, his Heirs and Assigns, for his said manor of Lyles, be not excluded from taking such benefit for his or their great Cattle there as the inhabitants shall or may do, according to the meaning of the articles herein mentioned and the orders hereupon, by, or according to these presents to be made.

And, that the said William Hinde, his Heirs and Assigns, Farmers and Tenants of the said Manors of Crowlands, Lyles, and Moiety of the Manor of Sames, shall, and may keep the number of milch kine, before mentioned, in such manner and form as is before mentioned, according to the true intent and meaning of these presents.

\section{ARTICLE XVI}

Also, it is agreed as aforesaid, that whereas the Inhabitants of Cottenham, aforesaid, have made a Bank and a Ditch in Smithy fen from the bars next unto North Fen unto the place called Stone-hill, that they, the said inhabitants, shall have and take twelve feet of ground there, for the ditch, and fourteen feet for the bank, for ever; and that the said inhabitants, their Heirs, successors and Assigns, shall, from time to time, cast, scour, maintain and keep all the fences and ditches about Smithy Fen, and also Charlode, for ever, and that all the banks and ditches in Cottenham aforesaid, which have been laid forth, made and staked by the said inhabitants, their heirs or assigns, or shall be by such their officers as shall be chosen, as hereafter is mentioned, shall be kept and maintained for ever in good and sufficient reparation, by those persons, their heirs and successors, to whom they be, or shall be severally limited, allotted, and appointed, to be maintained, scoured and kept; upon pain of $16 \mathrm{~d}$. to be forfeited and lost by those persons, their heirs, successors or assigns, to whom the said reparation shall be limited and appointed, for every pole, not sufficiently repaired.

Allowances for ditches and banks in Smithy Fen, and what forfeited if not maintained. 


\section{ARTICLE XVII}

Lords may plant the banks with wood and have the profit, with the fishing and Charlode to the town.
Officers to levy penalties.
And also it is agreed that any of the Lords in Cottenham, their heirs and assigns, and the Freeholders and Copyholders in Cottenham aforesaid, their heirs and assigns, may plant and set any kind of Wood or Willows, Oziers, Sallows, or other Wood upon that part or parts of the banks or ditches to him or them limited, to be repaired at his or their pleasures, and likewise that he or they which so shall plant the same, they, their heirs, and assigns, shall or may take the commodity thereof for ever. And the fishing and other profit of those parts of the ditches and banks, to them severally limited, to be repaired, and the same to use at his or their discretion as often as they or any of them shall think good and convenient, without any denial of any person or persons whatsoever, having right to any Estate of Inheritance of or in any Lands or Tenements within the said town, saving that the said Inhabitants of the said Town of Cottenham, their heirs and assigns, shall have the fishing of the said Charlode for ever, to be let by them, their heirs and assigns, to bear the common charges, whereby the said Inhabitants of the said Town shall or may be, in common or together, charged.

\section{ARTICLE XVIII}

And further it is agreed, as aforesaid, by all the said parties to these presents, for them and every of them, their and every of their heirs and assigns, that the Town Officers that shall be appointed from time to time by the makers of orders, by virtue of this agreement, shall and may levy by way of distress or of distraining of the goods and chattels of any person or persons which shall offend or neglect the performance of any of these orders, whether they be any of the Tenants of the said William Hinde, his heirs or assigns, or of any other, or otherwise which shall be found in any place in the said parish of Cottenham 
OF THE
UNIVERSITY
OF

aforesaid, all and every the amerciaments and penalties imposed, or hereafter to be imposed, upon any person or persons whatsoever, for the not repairing of the said banks and ditches wherewith they now are, or hereafter shall be charged by the judgment of the town officers for the time being, the penalties and amerciaments so taken and levied shall be bestowed and dispended upon the said banks and ditches, decayed, until they be sufficiently repaired.

\section{ARTICLE XIX}

And also it is agreed, as aforesaid, that Smithy Fen shall continue Robert Riand remain for ever dowelled and staked according as it now lieth, saving that the said Inhabitants shall have the fourteen roods that Robert Rivers had in Smithy Fen, which was laid by Sir Francis Hinde, Knight, deceased, to a cottage tenement, wherein the said Robert Rivers now dwelleth, in Cottenham aforesaid, belonging to the Crowlands hold; and that those fourteen roods shall be laid and dispersed into several parcels, one parcel of two roods to every fee, where the said Robert Rivers usually had the same, upon the outside of every fee next the stake or landmark for the parcels of the said fen belonging to the Manor of Burdlaries alias Harlstones, and that the said Inhabitants of Cottenham, their heirs and assigns, shall so take and enjoy the same hereafter for ever, and bestow the profit thereupon arising upon the common charges of the said town.

\section{ARTICLE XX}

Also, it is agreed, as aforesaid, that the said Inhabitants of The Town Cottenham, shall have to them, their heirs and assigns, all the to have the wood that is growing or that hereafter shall be growing in the ing in the common fens, wastes, and commonable grounds in Cottenham, to bear such the common charges as before mentioned, for ever; except, that every one, their heirs and assigns, shall or may take such of the said Wood as they or any of them have planted or 
shall plant, upon any of the said banks in the said Fens as is before mentioned, and except all woods now growing, or that hereafter shall grow, in any of the grounds now inclosed or meant to be kept several or agreed to be inclosed hereafter by [any] of these presents.

\section{ARTICLE XXI}

The Inhabi- Also it is agreed, as aforesaid, that the said Inhabitants, their bitants to have the leavings. heirs and assigns. shall, for the common use and benefit of the inhabitants, their heirs and assigns, of the said township of Cottenham, have for ever the use and profit of one piece of ground in Smithy fen called the Young Man's fen. And of one other piece of ground in the Holme, called the Bull Piece; and also the profits of the parcels of the said Smithy Fen, called the leavings, not set out or divided as is aforesaid ; and also the Fishing in the Abbot's Creeke and in the new ditch in Smithy Fen, saving that yearly after Michaelmas until the feast of the Annunciation of our Lady the Virgin, the said parcel of ground shall be used still in common as the other commons and wastes have been.

\section{ARTICLE XXII}

The form, and when the Order Makers are to be chosen and allowed.
Also it is agreed by all the said parties to these presents, for them, their heirs and assigns, that before the feast of the birth of our Lord God, next ensuing the date of these presents twenty customary Tenants or Copyholders of the Manors or Lordships in the Town of Cottenham shall be named and published in the Church of Cottenham by the Lords of the said Manors in Cottenham aforesaid, their Deputies or Farmers, in manner and form following : viz: the said William Hinde, his heirs, farmers or assigns, shall name of or for the Manor of Lyles five Copyhold Tenants of the said Manor. And, for the Manor of Crowlands. five Copyhold Tenants of the said Manor; and, for his or their moiety of the Manor of Sames, one Tenant; and that for the 
Manor of Burdlaries alias Harlstones, three Copyhold Tenants of the same Manor, shall be named there by the Master of Christ College in Cambridge, or the Farmers of the said Manor of Burdlaries, or his or their deputy ; and for the Manor belonging to the Rectory, three Copyhold Tenants of the same Manor shall be named by the Parson of Cottenham, for the time being, or his deputy or Farmer. And, there shall be then named by the Dean and Chapter of Ely and their successors, farmers or assigns, for the Manor of Pelhams, two Copyhold tenants of the same Manor: and that Thomas Alcock, his heirs and assigns or farmers, for his moiety of the Manor of Sames, shall then name one Copyhold tenant of the said Manor ; and upon or in default of such nomination to be made, by any of the said lords, their farmers or assigns, the Copyholders of every the said Manors, so named as is aforesaid, or the greater number of them, shall within one week then next following, nominate and appoint so many Copyholders of every of the said Manors as is aforesaid as shall not be nominated or appointed by the said lords, their farmers, or assigns, as is aforesaid : all which customary tenants so named, or so many of them as shall be so named and will ; the Farmers of the Manor or Rectory of Cottenham ; the Farmers of the Manor of Crowlands, if they will; and so many of the Freeholders of the same Town inhabiting there as will, shall on the twelfth day of January next coming, and yearly after, on every twelfth day of January, before ten o'clock in the forenoon (not being Sunday, if it shall fall upon the Sunday, then the next day following at the same time) meet in the Chapel in Cottenham aforesaid, sometime used for a school-house, and that they or the greater number of them that do so meet, shall and may make Orders and Bye-Laws, for the feeding, mowing, ditching, fishing, or other convenient usage of all the Fens, Wastes, and Commonable Grounds, in Cottenham aforesaid, and assess Pains and Penalties of or upon the breakers of the same or any of them. And that the said twenty customary tenants, so named as aforesaid, or so many of them as shall be so named to be Order Makers, in manner and form as is herein mentioned, shall so remain and 
continue for and during their natural lives, or until they shall leave their dwelling and habitation in the said town of Cottenham, and whensoever, any of the said Copyholders, shall die or depart from his said habitation in the said town, then the lord or the owner of the said Manor, for which the said Copyholders so dying or departing as aforesaid was nominated, shall nominate before the feast of the nativity of our Lord God, next ensuing such death or departure, in his place or stead another Copyholder or customary tenant of the same Manor of or for which the party dying or departing was named, in manner and form aforesaid; and upon default of such nomination, as aforesaid, by any the lords or their deputies, then it shall be lawful for the rest of the said Order makers, or the greater number of them which shall be nominated from time to time, to nominate or appoint so many of the Copyholders for every of the said Manors as shall be wanting of the number or numbers aforesaid to meet and make Orders in manner and form aforesaid ; and the parties so to be nominated to do and execute all and every thing as the parties so first named did or might do according to the true meaning of these presents.

\section{ARTICLE XXIII}

How all the Also, it is further agreed, as aforesaid, that all the sums of Money Penalties accepted for banks and ditches shall obtained or levied by reason of any the Pains, Penalties or Forfeitures, forfeited or lost by virtue of this agreement, or by any be bestowed. order hereafter to be made by the said Order-makers, or the greater number of them, in manner and form aforesaid, except for the banks and ditches, shall be divided and paid as follows; (that is to say), the one half of the said pains, forfeitures and amerciaments, so levied shall be paid to the lord of whom the tenement is holden whereby the person forfeiting any penalty doth claim to have or use any common there ; and, the other half shall be paid, the one half of the last mentioned to the use and profit of the said Inhabitants to bear the common charges of the said town of Cottenham, and the residue they the said officers may retain to the use 
and profit of the said officers, in consideration for their said pains.

And it is further agreed as is aforesaid, that the Orders and All orders Bye-Laws, and Pains, so made and agreed upon by the said Order-makers, or the greater number of them, being not contrary nor repugnant to the true intent and meaning of the parties to these presents in this book expressed, shall stand and be good and available and be kept until some other Order in that behalf be made by the said Order-makers or the greater number of them at authority. the like time assembled, whether the consents of the lords or owners of the said Manors, or any of them, or of any other tenant or owner of any lands, tenements or hereditaments in Cottenham aforesaid, their or any of their heirs, successors or assigns, be had or not; provided always that the said Orders and Bye-Laws, nor any of them, shall not extend to the rating of the said Inhabitants to any certain number of cattle, except milch kine. And if any rate for milch kine shall be made hereafter, it shall extend to all the inhabitants in general, and not that any one person that hath right of Common for keeping milch kine, according to the true intent of these presents, shall be rated to keep more milch kine than another, saving, that it shall be lawful for the parson of the Rectory of Cottenham to keep eight kine, above the rate, so that he keep not above twenty kine in all, at one time.

\section{ARTICLE XXIV}

And it is also agreed, as aforesaid, that the said makers of Orders shall within fifteen days after the making of the said Orders cause the same to be put in writing and published in the Parish Church of Cottenham aforesaid; and shall at the same time that they do make Orders, appoint yearly two of the Inhabitants to be Officers after made. for the town for one whole year. And that the said two Officers shall see the said Orders and Bye-Laws, so made and agreed upon, kept and performed, and, as well the said Bailiffs of the said Lords shall or may distrain for and levy the one half of the said penalties,

Orders to be wrote and published in the Chapel within fifteen days made by the Makers, not repugnant, shall be in force till they be repealed by the like

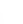


forfeitures and amerciaments due to the said lords as is aforesaid, and also that the said Officers shall or may distrain for or levy the other half of the said penalties and forfeitures, which shall be forfeited for the breach of any Article contained in this Composition or Agreement, or of any Orders or Bye-Laws, that shall be made as aforesaid, to be employed as is aforesaid. And it is further agreed, as aforesaid, that as well the said Officers as also the said Bailiffs of the said Lords, for their portion, shall and may distrain the beasts or goods of him that doth refuse or delay to pay the same amerciaments or pains forfeited by him, wheresoever they be found in Cottenham aforesaid, so they be distrained for within one year after they be forfeited, and not otherwise, and impound the same distress or distresses until the money be paid for which they were distrained and sell the same distress if the money be not paid within five days after such distress impounded. And that the said Officers shall make a true and just account of their receipt of all and every the penalties, forfeitures and amerciaments that they shall so receive or levy, unto the Order-makers, or the greater number of them, at the time, place and day of their next meeting for making of Orders, and that the said Officers shall yearly within eight and twenty days, next after their accounts to the said Ordermakers made and determined, pay all such sums of money as shall be then remaining in their hands, that is to say, so much as is due to the inhabitants shall be paid by them to the Town Officers, newly chosen, for the next year following, upon pain to forfeit double so much money in the name of a penalty, as shall then remain in their hands unpaid, the last mentioned penalty to be employed to bear the common charges of the said inhabitants.

No Laws to be made in any of the Lord's Courts.

\section{ARTICLE XXV}

Also it is agreed, as aforesaid, by and between the said parties to these presents, and every of them, for them their heirs and assigns, do grant and agree to and with either of them their heirs and assigns, that neither the said William Hinde, nor any of his 
heirs, executors administrators or assigns, nor any other lords, lord or owner of any other Manor in Cottenham aforesaid, or any their jurors, homage or tenants, or suitors of or to any Court or Courts of any of the said Manors in Cottenham aforesaid, shall make or suffer to be made in any Court or Courts of the said Manors or of any of them any Order or Bye-Laws touching or concerning any Order or Article herein mentioned, or touching or concerning any Order or Bye-Law, according to the true meaning of these presents to be made by the said Order-makers, in manner and form aforementioned, nor shall distrain for or levy any fines, but shall, if they will, from time to time ratify and confirm in their courts all or any of the said Orders so made or to be made by the said Order-makers as is aforesaid, and the said lords shall not distrain for nor levy any fines, pains or amerciaments touching anything of or for or concerning the which any pains or amerciaments shall or may be assessed or levied by the true meaning of these presents, other than for such as his or their moieties as is aforesaid.

\section{ARTICLE XXVI}

And also it is agreed, as aforesaid, that no person or persons What pershall use or enjoy any of the Commons or Liberties of Commonage, sons are to within the bounds or limits of the said Town or places of Cotten- mons. ham Commonable aforesaid, for any longer time than his family be or shall be inhabiting or resident in Cottenham aforesaid, and that he keep no house in any other place than in Cottenham aforesaid ; provided always that it shall be lawful for John Russel, gent., and the said Thomas Alcock, gent., during either of their lives, to Common there with all manner of their cattle, in respect of their lands and tenements there, in such sort as the rest of the inhabitants do, or may lawfully common, although that they and their wives be not couchant there, so that their families be resident there; neither shall any person or persons common or use any feeding or pasture in common but only for one tenement, and that for the tenement whereupon he or his family dwelleth or coucheth; 
saving that it shall be lawful for the said Mr. William Hinde and his heirs males, not inhabiting in the said town of Cottenham, for his said Manor of Lyles, to have feed for his or their own proper great cattle in such places, and in such sort, and at such time as the said inhabitants, their heirs and assigns, shall keep and feed their great cattle; provided always that the said William Hinde, his heirs and assigns, shall and may keep the milch kine before mentioned in manner and form as is before set down and ordered. Provided also, that if at any time hereafter the said Order-makers shall rate the inhabitants to any certain number for milch kine, that then the said William Hinde, his heirs and assigns, shall be rated and stand to keep as the other inhabitants do for his and their Manors of Lyles and Crowlands, and not otherwise, any thing in these presents to the contrary notwithstanding. Provided also, that it shall be lawful for the Parson of Cottenham aforesaid and his successors, keeping and performing the Covenants and Articles hereafter mentioned on his part and behalf to be performed, to have the feeding of his own proper great cattle and three score sheep, in the said Commons of Cottenham, not couching in the said town, and that at such time or times and in such places as the inhabitants shall feed their own cattle, so long as he doth keep the said Articles and covenants on his behalf, the which sheep and cattle shall be for the maintaining of the hospitality and housekeeping of the said Parson in the said parsonage of the said town and not elsewhere; and the said Parson of Cottenham doth for him and his successors and assigns grant and agree to and with all the other parties to these presents, and every of them, their heirs and assigns, that in consideration of this grant of Commonage and of his said Inclosures that he, the said parson of Cottenham, nor his successors nor assigns, shall not demand or take hereafter any tithes which have not heretofore been usually paid, within three score years now last past, before any inclosures were made by the said Sir Francis Hinde, knight, or his assigns, within the bounds of Cottenham ; provided, that if any arable land in the common fields of Cottenham aforesaid, shall 
be sown with any seed whatsoever, that the tithe thereof shall be paid in kind.

\section{ARTICLE XXVII}

Also, it is agreed as aforesaid, that no person or persons shall What Cattle put any kind of cattle into any part of the Common belonging to to be put on the said town which be not his own proper cattle, except such as by these presents are mentioned to be excepted, and also except such cattle as any person inhabiting in Cottenham aforesaid, with the allowance of the said Orders-makers or the greater number of them, shall have to draw in his cart or plough, and kine to milk for the relief of his house, and they to go in such places as the other inhabitants' milch kine and working cattle do go.

\section{ARTICLE XXVIII}

Also, it is agreed as aforesaid, that all the ground between Dividing Chittering $\mathrm{Hill}$ and the Lot ditch next Topymoor shall be laid Lots and several and kept from all manner of cattle, yearly hereafter for Calves. ever, from the first day of March until the four and twentieth day of June, and so long after as the greater part of the Order-makers shall think meet and convenient; and, that the same ground, yearly upon the morrow after Midsummer day, or at such time as the greater part of the Order-makers shall think meet, shall be by the Town officers or their deputies parted, divided, and allotted, evenly and indifferently, into lots and parts amongst all the said lords and inhabitants in Cottenham aforesaid having right of Common in the said town of Cottenham, to the end that every of them may mow and convert into hay or stover all their and every of their parts so to them assigned and allotted. And, that BullocksHarst, Dellfen, Alborowe, and all other grounds between the Close at King's-Cross-Way and Crykle Fen bank, and the ground aforesaid adjoining to Marehill and Crykle Fen, which was heretofore Common and lately inclosed and now laid Common again, shall 
be kept several from all manner of cattle from the twentieth day of February until the first day of May, yearly, for ever hereafter, except so much ground as is between the said King's Cross Close and the clay pits, to be used for the weaning of Calves and to be several as aforesaid ; and, that after the first day of May until the latter end of harvest no manner of cattle shall be fed or depastured in the said grounds and places before mentioned, except milch kine or such kine kept to be milch the next year following, and bulls, as shall be allowed by the said Order-makers or the greater number of them, except Weanling Calves in the grounds before excepted for calves; and, that the ground called Michelleye and all the ground lying between Crykle Fen bank and the Lots ditch in Topymoor, shall be yearly laid several and kept from all manner of cattle from the twentieth day of February until the first day of May, and from thence until the first day of November, no jeest cattle shall be depastured there except oxen which do work in the plough or cart, and burlings under the age of one year, and sick bullocks. And, no sheep shall be depastured in any of the said last mentioned grounds, but only from one month before the feast of the nativity of our Lord God, yearly, unto the twentieth day of February and no longer, upon the pain of Sixpence to be forfeited for every sheep, by the owner thereof, which shall feed or depasture in any of the said last mentioned grounds, contrary to this Article.

\section{ARTICLE XXIX}

When, and why and by whom, the keepers of the fen, are to be chosen and appointed.
And, it is agreed as aforesaid, that yearly upon the Sunday before Candlemas day, after Evening prayer being ended, or within twenty days next before the said Sunday, two Men, or more shall be chosen or hired by the greater number of Inhabitants, being present in the Church of Cottenham aforesaid, having right of Common in the said Town and Fens, to keep the said grounds and places from cattle for and during all the times that they are to be laid and kept several in such manner and form as is before 
mentioned, which keepers or their deputies shall not suffer any cattle to go or feed in any of the said grounds or places, otherwise than is appointed by this Article or shall be appointed hereafter by the said Order-makers or by the greater number of them. And then also in like manner two other persons or more shall be chosen as aforesaid to impound all such cattle as they find feeding in any of the said grounds or places, contrary to any Article contained in these presents or contrary to any Order hereafter to be made by the said Order-makers or the greater number of them. And the cattle so impounded shall from time to time be redeemed out of the pound at the costs and charges of the said parties so as aforesaid chosen and hired to be the said keepers. And if in default of the said keepers or their said deputies the owners of the said cattle shall at their own charges redeem their own cattle so impounded out of the pound, then they may abate so much of the said keepers' wages as shall be paid for redeeming of the said cattle. And that every person shall yearly pay for his said lot or part, which he hath of or in the said ground lying between Chitteringhill and the Lott ditch next Topymoor, four-pence, and for every milch cow, which shall be kept or put before any of the said herdsmen of either of the milch herds, between the first day of May, and the four and twentieth day of June, one penny. The which sums of fourpence and one penny shall be employed and paid towards the payment of the said keepers' wages; and that every person that shall not pay all the said money to such persons as shall be appointed to collect the same within ten days next after the same shall be demanded, shall lose his lot aforesaid for that year, the which lot shall be sold by the Town Officers abovementioned for the time being and the money thereof coming shall be employed toward the bearing of the common charges of the Town, and also towards the payment of the said keepers' wages. And if there shall not be hired any keepers as aforesaid by the Inhabitants in manner and form specified in this Article, then the said Town Officers or their deputies shall and may impound all such cattle as they shall find 
going and feeding in and upon any part or parcel of the said ground, contrary to this Agreement or to any order hereafter to be made by the said Order-makers, or the greater number of them. And the said cattle so impounded there to detain and keep until every owner thereof do pay for the first time that his cattle shall be so impounded two pence, and for the second time within the same year, three pence, and for the third time within the same year, four pence. And if he or they shall have this warning three times and therein be taken offending in like manner afterwards, with his cattle in the same year, then to pay Sixpence for every Pounding, so often as they shall be taken unto the said Officers or Impounders.

\section{ARTICLE XXX}

For Cowway.

Also it is agreed, that the way called Cow-way, now used, leading from a place called Wronglane's End unto the Cow Pasture within the limits of Cottenham aforesaid, shall continue for ever to be from time to time used as a Way only, as well by all and every the parties to these presents, their heirs and assigns, and all other the Inhabitants of Cottenham aforesaid which do and shall consent and shall continue their consent and agreement to this present Composition, and by none other, for the drift of their kine and other cattle, and also for their passages and carriages whatsoever necessary for their several uses. And, that the said William Hinde, his heirs and assigns, shall before the feast of the Annunciation of our Lady, next ensuing the date of these presents, upon reasonable request thereof made, convey unto any person or persons and their heirs, upon whose lands the said Way lieth, so much other land in quantity, not holden of the Queen Majesty her Heirs or Successors by Knight Service in chief, as whereof the said persons do or shall lose the profit by reason of the said Way. 


\section{ARTICLE XXXI}

Also it is agreed, as aforesaid, that so much of the Commun Mr. Hinde Drain as lieth within the inclosure of the said William Hinde, his the Drain heirs or farmers, leading from the Dunstall Field unto Landbeach and Tillage. Fen side, shall be by the said William Hinde, his heirs, assigns or farmers, at his or their charges, well scoured, maintained and kept from time to time for ever.

\section{ARTICLE XXXII}

Also, that Smithy Fen shall be yearly, from the feast of what time St. Michael the Archangel, kept from Sheep until the twentieth day kept out of of February, hereafter for ever. kept out of
Smithy Fen.

\section{ARTICLE XXXIII}

Also, that no person or persons having right of Common in For Coloring Cottenham aforesaid shall suffer by way of Coloring, the Cattle of any person or persons in Cottenham, neither the cattle which he shall have jointly or in common with any person or persons, to be depastured or fed in his right or name in any part of the Commons of the said town of Cottenham, except all such joint owners or owner in Common of Cattle as have Common in the said Town and be dwelling there, upon pain to forfeit and lose for every beast so depastured and fed, contrary to this Article, thirteen shillings and fourpence, and, the said money to be paid to the said Town Officers and to be divided, distributed, and accounted for, as is aforesaid.

\section{ARTICLE XXXIV}

Also, that no Swine shall be suffered but only by way of drift For Swine, to go and feed in Smithy Fen, Bullocks Harst, Mitchelleye, nor whall go, from the Stone Bridge to the Becks, Delffen, Alborowe, in the 
ground between King's-Cross Close and Crykle Fen Bank, and from thence to the Lot ditch in Topymoor nor in the Lots, at any time hereafter, upon pain that the owner, knowing thereof, shall lose for every swine for every time going and feeding contrary to this Article, four-pence, to be divided, levied, and distributed and accounted for as aforesaid.

\section{ARTICLE XXXV}

For ByeHerds.

Directions for choosing Field Reeves and Fen Officers.

Also it is agreed, as aforesaid, that yearly from Candlemas until the first day of November, no person or persons shall keep any Bye-Herds of great Cattle, or put any bullocks to be depastured in any part of the Commonable Grounds or Fens belonging unto the said town of Cottenham but before the Town Herdman, upon pain of twelve pence for every offence, to be levied of the offenders goods and divided, distributed, and accounted for as aforesaid, except in Little North Fen and Great North Fen; and except Working Cattle, sick Bullocks, Burlings under the age of one year, Horses, Mares and Geldings, in manner and form as in this Article is agreed, and not otherwise.

\section{ARTICLE XXXVI}

Also it is agreed, as aforesaid, that those persons which by the true meaning of these presents shall be appointed to make Orders and Bye-Laws, or the greater part of them, shall at such time as they do meet, appoint and choose two men of the inhabitants to be Fieldreeves, which Fieldreeves shall see such Orders and Bye-Laws kept and performed as shall be made and agreed upon by the said Order-makers or the greater number of them, for the water furrowing and gripping of the fields. And shall likewise at the same time appoint and choose two men, being of the said Inhabitants, to be Town Officers, which Town Officers or their deputies shall see all the Articles and orders now made and hereafter to be made, performed and kept by virtue of this agreement; and that the said 
Officers or their deputies shall collect and gather the aforesaid keepers' wages; and shall also divide into Lots all the ground mentioned in these presents to be divided and allotted to that purpose, before the fifteenth day of July, yearly. The which Officers shall have each of them for their pains taken about those things some outcast or leaving of the said ground, so that either of their parts by good estimation be not above the value of twenty shillings. And that the said officers shall have power and authority to levy and distrain and take all the penalties, pains and forfeitures for the breach of all and every Article, Order and Bye-Law, made or hereafter to be made by virtue of this agreement, to be divided as aforesaid. And the Fieldreeves shall have the like authority for any Order and Bye-Law made for the Fields, and the money thereof coming to divide, distribute and account for as aforesaid. And if any person or persons, so chosen by the Order-makers as is aforesaid to be the Town Officers or Fieldreeves, do refuse and neglect to execute the same, every such offender shall forfeit three pounds, six shillings, and eight pence, to be levied by distress and to be divided, distributed and accounted for as aforesaid.

\section{ARTICLE XXXVII}

Also it is agreed, as aforesaid, that the said William Hinde, his heirs and assigns, shall not molest or trouble any of the said For Pales Inhabitants, their heirs and assigns, for any Pales, Walls, Hedges, or other fences standing before their Houses towards the Street in the said Town at this time, and shall suffer them and all such like Fences hereafter as shall be set up, to continue and remain and be maintained for ever; so that they which shall be hereafter made shall not stand further into the Street than without the compass of the outmost part of the eaves' drop of the house. 


\section{ARTICLE XXXVIII}

For Suits commenced against any Officer.
For those who willingly break this Agreement.

Also it is agreed, as aforesaid, that if any Suits shall happen to be commenced against any of the said Officers for any thing to be done by them or any of them, by or concerning their office and this agreement, the same Suit or Suits shall be maintained and borne, the one half by the parties above named, their heirs and assigns, and the other half by the said William Hinde, his heirs and assigns.

\section{ARTICLE XXXIX}

Also it is agreed, as aforesaid, that if any person or persons which now hath or hereafter shall have any Right, Interest or title of Common within the bounds of Cottenham shall willingly break this agreement, or interrupt the same or any part thereof, then the said William Hinde, his heirs or assigns, shall bear or sustain the one half of the charges which shall be spent in the Law about the same, and the party above named, their heirs and assigns, shall bear the other half thereof, until the cause shall be by Law determined, and if any recovery or eviction hereafter had or made against any of the parties above named, their heirs or assigns, of any thing, benefit or commodity, contained in this agreement, by any act or acts heretofore done by the said Sir Francis Hinde, Knight, or by any claiming by, under or from him, or done or hereafter to be done by the said William Hinde, his heirs or assigns, or any claiming by, from, or under him, for any his Lands or Leases, wherein he had right, title or interest, or shall hereafter, that then the said William Hinde, his heirs or assigns, shall make sufficient recompence for the same, and shall then also yield unto the said parties and every of them, their heirs and assigns, such damages, charges and costs, as they or any of them shall sustain by reason of the loss for not having such profits and commodities as they ought to have had by virtue of this agreement. 


\section{ARTICLE XL}

Also it is turther agreed, as aforesaid, by and between the said parties, th ir heirs and assigns, that such of the above named parties, their heirs or assigns which shall not consent, agree, and continue their consent unto this agreement, and shall not subscribe their names to these presents at such times as they shall be required sh il receive no benefit by any Article or thing contained herein, until he or they do consent and subscribe their names or marks unto the Articles of this agreement, any thing to the contrary notwithstan ling.

\section{ARTICLE XLI}

Also it is isreed, as aforesaid, that all the charges of passing and For the perfecting of these Articles of Agreement, and of all other assurances concernin the same which shall be reasonably devised by Council Book. learnerl in the Law of the said William Hinde, his heirs and assigns, mo the parties abovesaid, their heirs and assigns, shall be horne unt if erently by the said William Hinde, his heirs and asiiuns, and the said parties, their heirs and assigns. And that ten pound expended and laid out by George Pepys, gent., and also all othe ars $\quad$ heretofore spent sithence the feast of Easter in the seven d hirtieth year of her Majesty's reign, in the behalf of the said Inhabitaits, about the controversy of the Inclosures made by the said Sir Francis Hinde, Knight, or touching the Common, or any part ot them, shall be borne indifferently by the said parties, their heirs and assigns, by any assessment heretofore agreed upon by divers of the said parties, which is for every tenement forty shillings, if it will serve, if not, to be paid by the money due, or hereafter to be due, unto the Inhabitants to bear the common charges of the Town of Cottenham aforesaid. 


\section{ARTICLE XLII}

For Droves and Drifts.

Mr. Hinde to make his Drifts.

\section{ARTICLE XLIII}

heirs and assigns, shall suffer the Town Officers and all other parties to these presents, their heirs and assigns, at any time hereafter, to put the Droves and Drifts of Cattle, which shall be at any time hereafter driven forth off the common fens or wastes, into the usual Drove yard of the said William Hinde, and that the said officers and other parties, their heirs or assigns, shall have authority to hold the said cattle, so driven into the said drove yard, until such time as they shall think good to deliver the cattle, so by them put in.

Also it is agreed, as aforesaid. that it shall be lawful to and for the said William Hinde, his heirs and assigns, to make his or their Drift of Cattle out of the Fens and Commons of Cottenham aforesaid yearly upon the feast day of Saint Michael the archangel, for the taking up of Strays, as heretofore have been used. Provided that if any decay shall happen to be in the Lyles Farm yard, by reason of the Inhabitants impounding of their said cattle, that the same shall be repaired at the costs and charges of the Inhabitants of the said Town of Cottenham.

\section{ARTICLE XLIV}

To consent to Ratify to bring this Decree to an Agreement.
Also it is agreed, as aforesaid, that the said William Hinde, his heirs and assigns, and all other parties to these presents, their heirs and assigns, shall, as much as in them lieth, procure and assent to have all the premises Ratified and concluded by decree in Chancery by Act of Parliament, or both, or otherwise, assured howsoever, as the learned Counsel of the said William Hinde, his heirs or assigns, and of the said Inhabitants shall devise. In consideration of all which premises before contained by these presents, 
the above named parties to these presents (except Edward Blean, Thomas Smith and John Bull) do every of them by himself respectively, by these presents, covenant, and grant, for the heirs, executors, farmers, and assigns, of every of them by himself respectively, to and with the said William Hinde, his heirs and assigns, that every of them respectively, their heirs, executors, farmers and assigns, will content and pay, or cause to be contented and paid unto the said William Hinde, his heirs and assigns, for every of their several Lordships, Messuages, Tenements, Freeholds, Copyholds or Leaseholds, respectively, thirty shillings apiece, of lawful money of England, as parcell of the forty shillings levy aforesaid, towards the payment of the three hundred pounds of like lawful money of England, at or in the Church Porch of Cottenham aforesaid, upon the five and twentieth day of March, which shall be in the year of our Lord God one thousand five hundred and ninety eight; which three hundred pounds is granted unto him the said William Hinde, in consideration of this present agreement. And the said above named John Russel, Thomas Jackson the elder, George Pepys the elder, Robert Banks, Thomas Jackson the younger, Thomas Humfrey, and John Brigham, the elder, being the seven men, receivers of the rents of the Lands, given towards the common charges of the said Town of Cottenham, do further covenant, and grant to and with the said William Hinde, his heirs and assigns, by these presents, that they the said John Russel, Thomas Jackson the elder, George Pepys the elder, Robert Banks, Thomas Jackson the younger, Thomas Humfrey, and John Brigham the elder, or some of them, will pay or cause to be paid at the Church Porch aforesaid, one and fifty pounds of lawful money of England, towards the payment of the residue of the said aforementioned sum of three hundred Pounds, upon the first day of November, which shall be in the year of our Lord God one thousand five hundred and ninety eight, until which said day it is provided by these presents, the said seven men or some of them, shall receive and take towards the payment of the said fifty one pounds all the 
rents and commodities that shall or may be levied or made of the aforesaid parcels, which are before by these presents granted by the said William Hinde, to the said inhabitants their heirs and assigns, to bear common charges, any thing herein before mentioned to the contrary notwithstanding. Provided always that if all the rents and commodities that shall be made of the premises, before granted by these presents to bear common charges, and of all other lands and tenements whereof they are appointed to receive the rents, will not before the said day amount to the sum of fifty one pounds, over and above all other charges and expences which shall be by them laid out for the said Township, that then the said seven men shall still receive and take the rents and commodities which shall or may thenceforth be levied or made of the aforesaid parcels, until they have received sufficient into their hands to discharge all the said fifty one pounds, and every part and parcel thereof.

\section{ARTICLE XLV}

To pay or give security for the three hundred pounds.
Also, it is agreed, that the said parties to these presents, their heirs and assigns and every of them, shall at or before the eight and twentieth day of May next ensuing the day and year first above written, give security by their several bonds to the said William Hinde, his executors or assigns, for the true payment of their said parts and portions, at the day and place by these presents limited and appointed, to be paid by them respectively, which is thirty shillings for every tenement, with interest for the forbearing of the same after the rate of ten pound in the hundredth for one whole year; provided that if the said parties to these presents, their heirs, successors and assigns, excepting such parties, their heirs, executors or assigns, as be or hereafter shall be farmers or servants unto the said William Hinde, his heirs or assigns, shall "ot give security by their several bonds to the said William Hincle, [his] executors or assigns, at or before the said eight and twentieth day of May, for the true payment of their said parts and portions, by these 
presents limited and appointed to be paid by them respectively, which is thirty shillings for every tenement, with interest for the forbearing of the same after the rate of ten pounds in the hundred, at the day and place by these presents agreed upon between the said parties to these presents, that then it shall be lawful to and for the said William Hinde, his heirs and assigns, to enter into the said great Inclosures called Longhill, and the same to hold and keep in severalty until they and every of them, their heirs or assigns, or some other parties for them, have either paid their parts and portions, with interest for the forbearing thereof as is aforesaid, or give security for the true payment thereof unto the said William Hinde, his heirs or assigns; and also for such costs and charges as the said William Hinde, his heirs or assigns shall expend in and about the fencing of the said inclosure. Provided further, that if the said John Russel, George Pepys the elder, Thomas Jackson the elder, Robert Banks, Thomas Jackson the younger, Thomas Humfrey and John Brigham the elder, or some of them, shall not by their bonds jointly give security unto the said William Hinde, his heirs and assigns, at or before the said eight and twentieth day of May, for the true payment of fifty one pounds at in or upon the feast of All Saints, which shall be in the year of our Lord God one thousand five hundred and ninety eight, at the place agreed upon by these presents, that then it shall be lawful for the said William Hinde, his heirs or assigns, to enter into the said Inclosures, and the same to hold and keep in severalty until they or some of them, or their succesors, have given security for the payment thereof as aforesaid. Provided also that none of the said parties to these presents, their heirs executors, administrators or successors, or any one of them, shall be charged or sued by virtue of any Article in these presents contained, for or by reason of the breach or non-performance of any of the said Covenants or Articles, contained in these presents, other than for or by reason of the breach or non-performance done or committed by himself, or those whose estate he hath, which so shall be sued, his heirs, executors, administrators, or successors; excepting the heirs, executors or 
administrators of the said seven men for the said sum of fifty one pounds.

\section{ARTICLE XLVI}

King's College Tenants to enjoy the Common.

Also it is agreed, as aforesaid, that all and every the Farmers and Tenants of the Provost and Scholars of King's College in Cambridge, for the time being, of those two several messuages or tenements in Cottenham wherein Thomas Holbeam and William Holbeam do severally inhabit shall or may for ever hereafter take and use the benefit of the Commons in Cottenham aforesaid, in such manner as the other Inhabitants of the said Town shall or may, according to the true intent and meaning of these presents, notwithstanding that the said Messuages or Tenements were of late newly erected and built.

\section{ARTICLE XLVII}

How any mistake is to be rectified.
And also, whereas it was agreed in one Article herein concluded, that if any question, ambiguity or doubt should be moved upon any matter, clause, or sentence, or word, which should not be agreed upon by the Learned Counsel of the aforesaid parties, that the same shall be referred unto the Right Honorable the Lord North, treasurer of her Majesty's Household, and one of her majesties privy counsel to be decided for all parties. Now, to testify that the said Articles are concluded and agreed upon, by the agreement of the Council of both parties, the said Lord North hath hereunto pleased to set his hand; Roger Goade, Provost of Kings; William Hinde ; Umfrey Tindall; Thomas Nevill ; Edmund Barwell, Master of Christs ; John Russell ; Richard Scott ; George Pepys, the elder ; Thomas Jackeson, the elder ; Thomas Jackeson, the younger; William Lovell; Robert Banks; William Treeve; Francis Brown; Thomas Humphrie; John Brigham, the elder; John Denson; John Brigham, the younger; John Ewsden, the elder; John Bull, the younger; Elizabeth Banks; John Philipe; 
Jeremy Hubberd; Thomas Mayle; Robert Pepys, the elder ; Edward Scott; Thomas Whitehead; William Collyn; William Briggs; Ralph Mullinex; William Jackeson; Thomas Hawkins ; William Lamb; John Fletcher; John Thacksteede; William Halden; William Denson, the younger; John Fanne; Nicolas Haylock ; John Maile, the younger; George Pepys, the younger ; Thomas Revers, the younger ; Richard Awsten ; Richard Frauncis ; John Ewsden, the younger; John Bankes; James Mayle; John Mayle, the elder; William Webb; Edward Bleane; Clement Cropwell ; John Halden; John Tayler ; Edward Norman ; Robert Philipp; William Saunderson; Edward Mayle; William Houlbeam; Thomas Houlbeam; Thomas Smyth; Thomas Ryvers, the younger; John Haddow, the younger; Rowland Browne ; Rowland Essex; William Causby; William Walker; Thomas Brigham; John Essex, the elder; Richard Norman; Richard Briggs; Thomas Haddow; William Fordham; William Emerson; Thomas Awsten ; William Leach ; Johan Curde ; Henry Leache ; William Philipp ; John Glover; Thomas Badcock; Elizabeth Norman; Robert Norman; Richard Emerson; John Roger; Robert Wimple; Thomas Roger ; Thomas Pepys, the younger ; John Haddow, the younger ; Thomas Wimple; Walter Reeve ; Thomas Vale ; Richard Bridgeman ; Richard Towneson ; Elizabeth Cambridge ; Richard Mayze ; Richard Caverly; Margaret Brown; John Mayze; Thomas Gibson ; Robert Pepys de Norff[olk]; Thomas Pepys, the elder; the Master of Saint John's College, in Cambridge; Robert Rivers ; Anthony Green; Richard Clayton; Thomas Watts; Richard Whitinge ; Edward Haldyn; William Moulton; Henry Gylate; Thomas Barnes; Edward Rymer; Robert Mayle ; John Norman; Henry Langham ; John Warryn; John Reade ; John Essex, the younger; Robert Barnard; Anthony James, and Thomas Richmond. 


\title{
O R D E R S M A E
}

\author{
AND AGREED VPON THE TWELFE DAY \\ OF JANUARY IN THE YEERE OF OUR LOR!) 1639. \\ FOR AND CONCERNINGE THE BEST B VEFII \\ AND CONVENIENT VSUAGE OF ALL THE \\ COMONABLE GROUNDS IN AND \\ ABOUT THE BOUNDES OF \\ COTTENHAM.
}

I. Swine forbidden to feede in the Lowfenns.

2. $Y \bullet$ number of swine.

No swine to goe upon Chitteringe.

\section{The penal-} tie for swine taken in $\mathrm{y}^{\circ}$ Cowpasture.

Imprimis, it is ordered that no Inhabitant in this Towne shal put or cause to be put any swine in or vpon any parte of the Arrable fields or comonable grounds, except they be so ringed that they roote not, vpon paine to forfeit for every swine so put contrarie to this Order, iiij. $d$.

Neither shal any swine vnringed be suffered to continue in any parte of the said Comons at any time after a dayes warninge given by the Bellman vpon the like paine for every swine, iiij. $d$.

And further that no persons shal put any swine to staie and feede in any parte of the Lowfenns nor in Great Northfen to continue therein at no time of the yeere, vpon paine to forfeit for every swine so taken, xij. $d$.

It is ordered that no person haveinge right of Comon shal not put or cause to be put into any of the said commons aboue the number of ten swine, vpon paine to forfeit for every swine aboue the said number, v. $s$.

And likewise that no swine shalbe suffered to goe vpon Chitteringe hill at any time upon the paine of vi. $d$. for every swine; and also if any swine shall goe by escape into any part of the cowpasture without the priuitie of the owners of them.

Then the sayd owners shal vpon warninge given by the Officer or Officers or any other person, within one day after, driue them out of such forbidden grounds vpon paine of such default for every swine so taken, vj. $d$. 
And if any Officer shal impound any swine offending as aforesaid before warninge given them as aforesayd, then $\mathrm{y}^{\mathrm{e}}$ sayd Officers shal take for every swine that they shall so impound but, iiij. $d$.

And it is Ordered that no swine shalbe kept and depastured at any time vpon Northfenside (except by waie of drifte, or except from Harvest to $S^{\text {ct }}$ Lukes day followinge vpon paine for every swine so kept, iiij. $d$.

It is ordered that if any persons shal cutt or pull downe, breake or carrie awaye any Oziers, Willowes or other sort of woode as hedges, gates stakes Railes, posts, barres, hardles, stonnes or any other thinge or thinges that are sett layinge or beinge in or vpon any parte of the commons of this Towne or any waie belonginge to this Towne without the priuitie and leaue of the Officers or one of them, then the partye or partyes so offendinge shal forfeit for every time so offendinge, $x . s$.

It is Ordered that before the $\mathrm{xij}^{\text {th }}$ daye of Aprill next comminge every commoner haveinge right of common in this Towne shal, with a stake marked with his or their vsuall brande, wherewith he brandeth his Geast bullocks ${ }^{1}$ or sheepe, marke out his parte or 6. The Order for stakeing and markeing of their bankes. Layer $^{2}$ of all his bankes, vpon paine of default or neglect thereof to forfeit vj. s. viij. $d$. to the towne officers for every layer not so staked or marked, and the penaltie to be bestowed as all other penalties for the good of the Towne.

And if it be prooved any person to have pulled vp or carried awaye any of the sayd stakes, he shal paie to the owner of the sayd stake so pulled or digged vp fiue shillinges. And the Officers shal give notice thereof to the owner of the sayd Stakes, and the owner thereof shal marke and stake it againe within three weekes after such notice given to him or them, vpon the like paine of fiue shillinges.

${ }^{1}$ Bullocks, a term which includes any cattle of full age, on agistment. See order 2I, below.

2 The portion of banks, or ditches laid out for each commoner to keep in order. Article XVI. 
7. For setting It is Ordered that no person vseinge fishinge shal neither lay of their Netts and Fishing. nor sett any engine or nett within the fenn side of the bankes to take any fish nor within ten poles of any Lakes ende or in or vpon any gull or Breach that shal or may happen vpon any mannes bankes Common place or stoppinge in or about the bounds of Cottenham, except they first hire them of the Towne Officers, vpon paine for every time so offending ten shillinges and the penall losse of their nett or engine so sett.

And that no person shal sett any nett in any Loade or Lake narrower then the full bredth of the same Loade or Lake where they shall sett, vpon paine of two shillings to be likewise forfeited as aforesayd.

8. Against It is Ordered that if any persons shal cutt or pull vp or putt those that make hauoke and spoile the bankes and Cresses. downe any parte of the fenn bankes, Stoppinges or Cresses in or about any part of the commons without the consent of the said Officers or the greater parte of the Ordermakers agreeing thereto, the partye so offendinge as afforesayd shalbe pained for every such default ten shillings. And if any servant offend as aforesayd, the Maister of the said Servant shal paie the said penaltie for him, ffor the $w^{\text {ch }}$ the sayd Maister may deteine somuch of the servants wages.

9. For It is ordered that no persons haveinge right of common in this proprietie or Towne shall put or cause to be put any sort of great Cattle or cattle both Sheepe (Except milch Kyen) into any parte of the Commons after Cottenham and Westwicke. $y^{e}$ twentyeth day of Aprill next vntill they be branded $w^{\text {th }}$ his or their vsuall brand for Sheepe or Bullocks, and so to keepe them continually, vpon paine for every beast and Sheepe not so branded as aforesaid, vj. s. viij. $d$.

And likewise that the Inhabitants of Westwicke shal marke and brand all their cattell in such sort as $y^{e}$ Inhabitants of Cottenham are enjoyned, in manner and forme before specified, before they shalbe put into any of the sayd commons, vpon the like paine of vj. $s$. viij. $d$. for every beaste.

Io. And all Cumoners to bring

It is Ordered that every Comoner in this Towne and Westwicke shal before Mayday next bring a Coppie of his Brande to $y^{e}$ 
Towne Officers by them to be put in a Booke $\mathrm{w}^{\text {ch }}$ may serue for their brand their better knowledge of bullockes horse and Sheepe, vpon the $\mathrm{y}^{\circ}$ Officers. paine of iij. s. iiij. $d$.

It is Ordered that if any Comoner in this towne or Westwicke II. Against doe put or cause to be put vpon any parte of the Commons of this Towne $\mathrm{y}^{\mathrm{e}}$ cattell of any other persons haveinge no right of common in this towne or shal set his or their brand vpon such Cattle, to the intent that such Cattle may feede or be suffered to goe vpon the sayd commons, every such offender shalbe pained in the sume of xx. $s$. for every beast or Sheepe so taken, if it be probably founde against him or them within one yeere after such offence comitted. And likewise the owner or owners of such Cattle shalbe pained for every such beast $\mathrm{xx}$. $s$.

It is Ordered that if any person leaue open any Raile or barre or gate whereby any Cattle may goe into forbidden grounds that every person that shal make such default shalbe pained for every such default comitted iij. $s$. iiij. $d$. Whereof xij. $d$. shalbe given to him or them that shal take such offenders $w^{\text {ch }}$ sayd penalties shalbe leuied of the same persons Maister or parents of such as shal so offend. And the Maister may deteine somuch of the servants wages.

It is Ordered that if any person haue any vnruly cattle $w^{\text {ch }}$ will 13 . For not be kept out of forbidden groundes by reasonable meanes, the owner or owners of such cattle shal vpon warninge given them cattel. remoue fetter or otherwise so order them as that they may be ruled and kept out of such forbidden grounds vpon paine for every such Beaste or default, xij. $d$.

It is Ordered that no Jades or other Cattle be suffered to goe or be depastured in any parte of the Cowpasture (Except milch kine) vntill $\mathrm{S}^{\mathrm{et}}$ Michael the Archangell next. And also that every person Sonne or deputie shall driue or cause to be driuen all their Jades I4. Jades excluded from feeding in the Cowpasture vntill and other cattle (Except before excepted) beyond barreditch into $\mathrm{S}^{\mathrm{t}}$ Michael. Michelleye, except the fennes be so drowned or overflowen by waters that the sayd Cattle may not there abide vpon paine for every such default, xij. $d$. 


\section{4}

COMMON RIGHTS A T

I5. Against driueing of cattle through Smitheyfen.

16. Against driueing of Cattle thorow the Cowpasture.
17. Sechal and $\mathbf{y}^{\circ}$ ground beneath Micheleye to be kept from Geast Bullocks.

18. Against drift Cattle and other drie Cattle of the Butchers.

And it is Ordered that no persons shall driue or cause to be driuen any sort of Cattle through Smitheyfen vnto any of the other grounds or feedinges next adjoyninge vpon it from the $\mathrm{xxv}$ day of March vntill $\mathrm{y}^{\mathrm{e}}$ first day of August, vpon paine to forfeit fiue shillings for every time so offendinge.

It is further Ordered that such persons as have Pastures in Alborough Closes, Longhill Denny, or haveinge any other severall grounds adjacent and layinge vpon the Cowpasture, shal not driue nor cause to be driuen any sort of Cattle through the Cowpasture not aboue twice in the weeke to and from their sayd pastures, from the twentieth day of ffebruary next vntill ye first day of May ensueinge, vpon paine for every time so offendinge contrarie to this Order to forfeit fiue shillinges. And that the Officers or any of them or any other persons that shal finde such default done by any other persons shal take of them $y^{\mathrm{e}}$ penalties as aforesayd.

It is Ordered that no sort of Geast cattle shal either feede or be depastured in the fen called Sechall nor beneath Michaelleye or any parte thereof on this side the new ditch vntill the first day of August next comminge, vpon the paine or penaltie of fiue shillinges for every Geast bullocke that feedeth there before the daye prescribed by this Order.

Item, it is concluded and agreed that no Jades shal goe into the Cowpasture, nor any Jades shal be put into Dunstall field nor into the Halme field ' vntill $S^{\text {et }}$ Michael the Archangell next, vpon paine to forfeit xij. $d$. for every beast taken contrarie to this Order.

Item, wee Order that no Comoner or Inhabitant, nor any other persons in this Towne haveinge any dealinge in buyinge of Cattle and vseinge droveinge, shal put any of their drifte Cattle to feede or be depastured vpon the sayd commons or any other parte of them, vpon paine to forfeit for every such offence $x \mathbf{x} . s$. And it is further Ordered that no Inhabitant in this Towne vseinge Butcherie shall put any sort of drye cattle $w^{\text {ch }}$ they or any of them shal happen to prouide for their dealeinge in their trade vpon any parte

1 The field which was in stubble, according to the regular rotation. The term has no relation to the Holm meadow mentioned below. 
of the Cowpasture, vnder the penaltie of xij. $d$. to be forfeited for every daye so offendinge.

It is Ordered that no Sheepe shalbe fedd or depastured in the 19 . They Lowfenns called Sechall Chairefen and Chitteringe hill and the Lotts from the $\mathrm{xx}^{\text {th }}$ day of March vntill such time as the Sheepe doe vsually goe in the Cowpasture.

And that no Sheepe be depastured vpon Bullocks harst vntill the $\mathrm{xx}^{\text {th }}$ day of ffebruary, vpon paine for every Sheepe so goeinge, iiij. $d$. It is Ordered that no bullockes shalbe fedd and depastured in Smitheyfen, or in any parte of the Comonable grounds or fields, from $S^{\text {ct }}$ Thomas day next vntill the $x x v$ day of March followinge vpon paine for every beast so goeinge, iij. s. iiij. $d$. It is Ordered that no cattle shalbe fedd or depastured in any parte of the Cowpasture from the $x^{\text {th }}$ day of ffebruary next vntill the first day of Maye followinge. Nor any Geaste bullocks to feede betweene the Newditche and Michaeley [gap] from the xxth day of ffebruary next ensueinge vntil Michaelmas, vpon paine for every beast taken there to forfeit, xij. $d$.

It is Ordered that no person or persons shall put, folde or depasture, or cause to be put folded or depastured, any manner of cattle whatsoeuer in or vpon any parte of the Halme field vntill one weeke after Harvest be ended, vpon paine for every beast there founde before the day prescribed, iiij. $d$.

It is Ordered and agreed that it shalbe lawfull for any person that hath right of common to depasture and feede any kinde of Cattle on northfenside and little Northfen. As also in the fallow field and common plate of ground betweene the closes at any time of the yeere, with free libertie nothwithstandinge any order herein mencioned and formerly made concerninge bye heards. ' Prouided also, by vertue of this Order, that it shal not be lawfull for any Commoner to put any of their milch Bullocks ${ }^{2}$ nor any sort of their geast bullockes whatsoeuer into Greatnorthfen from this instant xij day of January vntill the xxvj day of Aprill

1 Any herd kept apart from the main herd; see above, order 14.

2 See above, order 6 , note must not put any drie Cattle into the Cowpasture. 20. Sheep shal not goe in the Lowfen vntill convenient time that they goe into the Cowpasture 2I. The Halme Fielde is reserued from Cattle for a weeke after Haruest be ended. 
next comminge vpon paine to forfeit for every beast so taken, xij. $d$.

It is Ordered that no person or persons shal digge any earth in Northfen to carrie to any of their Landes, or otherwise to their vse in any sort, nor in the leames nor in any other grounds or places profitable and where cattle feede, vpon paine of iij. s. iiij. $d$. for every Loade taken from any such places contrarie to this Order.

22. The

Holme ditch to be scoured.

23. The number of milch keine and for keeping of Bulls.

Item, wee Order that all the ditch separateinge the Holme Meadow from the Arrable fields and extendinge vnto the Holme close shalbe well and sufficiently ditched and scoured accordinge to the discrecion of the fieldreeues and by the paines and charges of the owners and fermors of those Lands therevpon abuttinge, before the xxiiijth day of June next comminge in this present yere, vpon paine of default or neglect thereof to forfeit xij. $d$. for every halfe acres bredth.

And further that $y^{e}$ ffieldreeues or Officers, or some of them, shal make or cause to be made a barre gate at the entrance into the Holme in convenient time to preserue the sayd meadow from the feedinge of Cattle.

It is Ordered that no Comoner shal keepe aboue the number of xij milche keine vpon the Cowpasture, and for $y^{\mathrm{e}}$ sayd number of twelue keine, he shal keepe a sufficient Bull in the heard with them vntill Michaelmas followinge.

And likewise that no comoner shal keepe aboue the number of nine Milch Keine vpon the sayd Cowpasture (Except he keepe a Bull as aforesaid), vpon paine for every Cow aboue the sayd number of twelue, and nine allowed as aforesaid, ten shillinges.

24. No commoner to haue or keepe any of their number of Milch keine seclusively and aparte from the Milch heard.
It is Ordered that no Commoner or owner shal haue any Milch Keine to feede a parte and seuerly by themselues in the fen called Sechell nor beneath Michaelleye, nor in any parte of the Lowfenns, but that their number of xij milch keine, and all vnder $w^{\text {ch }}$ they esteeme for the benefit of milch keine shal goe in the Milch heard, and that in such manner as is accustomed and in the former Order mencioned and specified, vpon paine to forfeit fiue shillings for every milch Cowe that shalbe kept against this Order. 
It is Ordered that no persons haveinge right of Comon shal 25. No milch either Lett, lende giue or exchange vnder the terme of one whole yeere the milke of any kine to make $v p$ his or their number $w^{\text {ch }}$ hath the number of foure keine, vpon paine both to the owner hirer, Lender giuer and exchanger $\mathrm{x} . s$. either hired or otherwise letten forth by any commoner for their milke for less then the space of a yeere.

It is Ordered that no person shal keepe or cause to be kept any Cattle vpon any Baulks forrends or furrowes in this Townefields 26. Forrends and before Harvest be ended, but onely vpon his own Baulkes forrends or furrowes, vpon paine to forfeit for every beast so goeing and feedinge, v. $s$.

It is ordered that the Heardsmen and Shepherds shal not take to keepe any cattle of any other person or persons whatsoeuer but onely those of the Inhabitants of this Towne. And further that if the said heardsmen doe know of any such person or persons $\mathrm{w}^{\mathrm{ch}}$ doe take to keepe and cullur ${ }^{1}$ the cattle of any stranger contrarie to furrowes. this Order vpon any certaine intelligence of such Cattle so retained, the sayd Heardsmen and Shepherds shal giue notice thereof presently to the Towne Officers or to one of them, vpon paine that $\mathrm{y}^{\mathrm{e}}$ Heardsmen and Shepherds that doe contrarie to this Order shal forfeit x. $s$. for every beast. And if any person or persons being a Commoner and so offendinge, shal be pained for every such offence $\mathrm{x}$. s. and shal loose the benefitt of their common for a yeere and a halfe, after such offence done and justly prooved against him or them.

It is Ordered, condiscended and agreed by all and the greater number of the Ordermakers, that all the ground in the Vnclertakers peece, ${ }^{2} \mathrm{w}^{\mathrm{ch}}$ is contained within the compass of the new ditch and

27. Against Heardsmen and Shepherds that take in strangers Cattle.

\footnotetext{
1 For an owner of common right to colour cattle was to pass off as his own cattle which really belonged to a person who had no common right; see Preface p. r8r.

2 The Undertakers Piece or Adventurers Land in the lot book of the Bedford Local Commissioners. This had been set out, but from a variety of causes had not been entered upon by the Adventurers.
} 
for a time Chitteringe Hill next it, shalbe kept seuerall from all manner of and equally cattle from the first day of March next comminge vnto the $x^{\text {th }}$ day among the of July immediately after, vpon paine to paye for every beast Commoners. feedinge there against this Order, xij. $d$.

And that the Officers by them chosen this yeere, with the helpe and assistance of the Ordermakers or some of them, shal meete vpon the $\mathrm{x}^{\text {th }}$ daye of June next immediatly after to conferre about $\mathrm{y}^{\mathrm{e}}$ due disposeinge, orderinge, measureinge and impartinge of the same peece of ground indifferently and equally to euery of the Tennements that hath right of comon in this Towne in such sort as is conveniable by their discrecion.

29. No thist- And it is ordered and agreed that no persons shal cutt any les to be mowen, vnless $\mathbf{y}^{\mathbf{e}}$ Officers give leaue. 30. The Order for diseased cattle that shal chance to be taken feeding vpon the Commons.

31. To preuent $y^{e}$ infection of diseased cattle. thistles growinge vpon any parte of the Commons vnless they first obtaine leaue of the towne Officers, vpon paine to forfeit fiue shillinges for every daye.

It is Ordered that no persons shal put or cause or be put any horse or mare haueinge the maungie or scabbe, or haueinge farcie or any infectious disease vpon any parte of the Comons or vnsowen fields, vpon paine to forfeit for euery day that any such diseased Cattle shal goe, or feed vpon the aforesaid groundes iij s. iiij $d$. to be leuied by the Towne Officers or by one of them or their deputyes or by any other persons that will vpon the owners of such horses.

And further that no Inhabitant shal put forth to feede vpon any parte of the Commons any sicke bullocks of the Gargit vntill they be so whole that they dropp not, vpon paine for every beast so put xij. d. a day.

It is ordered that all diggers of Claye or gravill, shal fill and leuill vp their pitts as neere as they can, vpon paine to forfeit for every pitt not so filled as is required, $\mathrm{xij} d$. 32. Theorder And wee find it convenient and hereby do giue warninge that ueing of the bed of slaite between the closes.

no man shal digge or open any ground for claye or gravill any neerer the vsuall road waie then $y^{e}$ outside of the pitts that hath bein formerly opened for claye and gravill, from Cowaies ende to Longhill $[g a p]$, vpon paine to forfeit xij. $d$. for every loade digged 
within the compass hereby reselued and forbidden as aforesaid. Item, wee giue order that no man shal hereafter breake vp any of the Bed or quarie of Slaitestone $\mathrm{w}^{\mathrm{ch}}$ is growinge within the Comon plate of grounde betweene the Moorecloses, but onely for claye for their necessarie vses, vpon paine to forfeit $\mathrm{v} s$. for every loade of Slaitestone digged there contrarie to this Order.

And that all such persons who have formerly digged vp pittes for slaite their own priuate vse and comoditie shal fill and leuill vp their pitts as plain and as even as the Loosmyre will aford, and that before the xxiiij daye of June next comminge, vpon paine to pay for every pitt not so filled and leuelled $\mathrm{vp}$ as is here directed, five shillinges.

It is Ordered that no willowes shalbe cutt vntill they be six or 33. Willowes seuen yeares growth accordinge to $y^{\mathrm{e}}$ discretion of the Officers, to be prevnlesse it be vpon extremitie to make vp suddaine breaches or cutting. gulles, vpon paine to paye for every tree if they shall cut them contrarie to this Order to forfeit, xij. $d$.

It is Ordered that if any Inhabitant sendinge his servant Sonne or deputye to Comon daye worke or other businesse, that hereafter shalbe appointed to be done by the Officers, and when the sayd Officers shal finde $\mathrm{y}^{\mathrm{e}}$ said servant Sonne or deputie to be stubbourn or negligent to worke Or els refuse to doe all such businesse or tie on them. layer as shalbe to them assigned and appointed by the said Officers, then the partye so offendinge shalbe sent home and the Parent or Maister of such an offender shalbe pained for every such offence, xij. $d$.

It is Ordered that every Comoner in this Towne shal doe all 35 . An Order such dayes workes layers or partes as shalbe thought needfull to be done hereafter, and at such times and in such places as the sayd Officers shal appoint, vpon paine for every pole not done to the approbation and likement of the Officers to forfeit, ij. $s$. And for euery day that they shalbe called with a Carte, either to sende a Carte or ij. s. And for every daye for a man to come the first or second day or send, vj. $d$., vpon paine to forfeit for every day behinde after two dayes warninge xij. $d$. And for every Cart to enjoyne those $w^{\text {ch }}$ keepe teame and cart vnto such workes as in the order is expressed. 34. Against
such as are negligent in thelr comon dayes works and a penal-

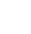


that is found behinde after the two dayes warninge given, ij. $s$. vj. $d$.

And in like manner wee doe Order compell and enjoyne every Commoner that receiueth the benefitt of keepinge the number of ten Bullocks in the Lowfenns ${ }^{1}$ in such regard shal vpon every such daye, and so often as shalbe founde requisite, either sende a Carte or two shillinges, or els to forfeit the penaltie of ij. $s$. vj. $d$. if such default be, and in such sorte as the residue in the former Order are pained.

36. For makeing $\mathbf{y}^{\circ}$ fen Bankes, and in what manner they are to be amended.
37. The penaltie to be imposed on such persons as doe make default in $\mathbf{y}^{\circ}$ amending of their bankes.

It is Ordered that every owner of Tennements and every ffermor for terme of yeeres shal, within ten dayes after warninge given them by the Bell, make and finish all their bankes in the fenns now layed or that shalbe indifferently layed and diuided vnto any of them by the said Officers in manner and forme followinge viz. they shal make euery of their sayd bankes foure foote hie and five foote broade on the toppe, and they shal digge all $y^{\mathrm{e}}$ Earth that they shal vse in makeinge and mendinge their bankes Betweene the River and the outcaste of their bankes, So that they come no neerer the banke then the middle of the olde ditch, if there be roome ynnough besids to make the banke; and if any person digge neerer than is here limitted, $\mathrm{He}$ shall fill and land vp all such digged places with Earth to be taken betweene the River and the banke as the River and ditches will give leaue. And if any person be found wantinge in maintaininge of his Bankes in manner and forme aforesaid, then the partye so offending shal paie to the towne Officers within six dayes after the sayd ten dayes so much as they shal laye out and so much more to the proper vse of the sayd Officers. And if the sayd Officers do not accordinge to this Article, Then the ffenreeues or stewards of any Lordship or any Tenant shal and may distraine the Officers and Offenders for such like penalties as the sayd Officers should haue distrained others, and shal doe in all pointes touchinge the bankes accordingly.

1 This was a privilege which was not included in the recognised common right, but had to be arranged for with the Order makers and paid for. 
It is Ordered and agreed by whole consent of the Ordermakers 38. The That the Officers by them nominated and chosen for this yere, together with the helpe and asistance of as many of the Ordermakers as will vpon notice given them, Shal in due and convenient time or season at or before the five and twentieth day of the Moneth of Aprill next comminge Or els so soone as the grounde is drie and will give leaue, Measure, limitt and allot equally and indifferently vnto euery of the Tennements haveinge right of Comon, One crofte or layer of turves to be digged, and every crofte or layer to be foure poles in length and xviij foote in bredth vpon the plaine in Chairefen, in such sort as is most conveniable by their discretion. Provided neverthelesse that no person shalbe suffered to digge or make their pitts aboue the bredth of a ditch or pitt of six foote broad and the length of one turffe in depth vpon paine for every person that diggeth contrarie to any pointe of this Order to forfeit, x. $s$.

It is Ordered that no persons whatsoeuer shal digge any Turves vpon the olde Layers being it is provided for them to digge vpon the new Layers $w^{\text {ch }}$ shalbe allotted to ech Comoner this present yeere after such sort and manner as is before recyted vpon paine to forfeit for every thousand digged against this Order x. $s$.

It is Ordered that every Comoner and Inhabitant shall scoure and ditch all the ditches of their lands ends wheresoeuer abuttinge or layeing by any of the Towne commons or any parte of them or any other Towne therevnto adjoyninge, as also all other ditches or gripes $\mathrm{w}^{\text {ch }}$ may serue for the better draineinge of the arrable fields belonging to this Towne in such manner and forme as shalbe appointed by the ffield Reeues. And all such ditches shalbe ditched and scoured and so maintained in such manner before mencioned in all points from this $\mathrm{xij}^{\text {th }}$ day of January now instant vntill the eleuen day of January next ensueinge.

And the ditches in the fallow field shalbe made in the same sort 40 . Further within fiue dayes after warninge given them, vpon payn to forfeit duties of the to the ffield Reeues for every default twice so much as the field Reeues shal laye forth and dispend in and aboute the sayd ditches.

Order for digging of turues vpon the Layers disposed vinto euery Comoner. And after the same sort to be taken for iij yeeres to come and this yeere next coming is the first for the same Layers.

39. Lands ends to be ditched for $\mathrm{y}^{\mathrm{e}}$ better draining of $y^{\bullet}$ fields. Fieldreeues. 
And it is hereby further ordered, condiscended and agreed that the sayd ffield reeues shal doe or cause to be done all the rest of the ditches aforesayd $w^{\text {ch }}$ are not so done within fiue dayes after the time appointed, and shall distraine the offenders for all such offences, $w^{\text {ch }}$ said penalties shal remaine to the proper vse and benefit of the feelde Reeues. And if the ffieldreeues shal make default herein, then the Towne Officers shall haue full power to doe and execute therein and shal see the worke performed and shal take the penalties forfeited as aforesayd.

4I. Penaltie on those $w^{\text {ch }}$ doe offend against the Composition or that repugne any of these Orders.

42. Cattle feeding contrarie to the Composition to be impounded by the deputyes Fenreeus hawards.
It is ordered that if any person offend against the Composition or against any Artycle therein contained, Or against any Order made by the Order makers, Then the Towne Offycers or their Deputyes or servants or any other person, being a Comoner within three dayes after they shall haue knowledge given them by an Inhabitant $w^{\text {ch }}$ will justifie and warrant their knowledge to be true, Or of their owne knowledge doe know of any such persons so offendinge, Shal and may distraine the offender or offenders and leuie the penaities that they haue forfeited. But if the Officers neglect to cloe as aforesaid, Then the Officers shal forfeit to him or them that gaue such notice so much as the Offenders should haue forfeited, $w^{\text {ch }}$ forfeiture the partye or partyes that gaue such knowledge shal and may distraine the Officers and leuie so much of their goods.

And further it is Ordered that the Officers or their deputyes, ffen Reeues, Hawards or any other person whatsoeuer dwellinge in this Towne, shal and may impound any Cattle wheresoeur goeinge or feedinge contrarie to any Artycle in the Composition or any Order now made and agreed vpon. As also any Cattle goeinge in Smitheyfenne contrarie to the vsuall custome, so that the fences be sufficiently made and maintained.

It is Ordered that the Officers shal cause to be made double fallinge Gates "at the waies and places where they haue bein vsed, viz. at the entrance into Michelleye and Toppymore, and also at the Lakes ende, and so to keepe them at the charges of the Towne.

1 A pair of gates shutting in the middle between the two posts. 
It is Ordered that at such time as the Town Officers shal make 43. Hawards any drifte (sic) out of the ffenns,... all the Hawards of every manner to assist the any drifte (sic) out of the ffenns,... all the Hawards of every manner Towne or Lordship or two of them shall at all times, vpon warninge given them by the Officers or either of them or their deputyes, Helpe, Officers at their drifts. vp with all such drifts of Cattle as they shal make, vpon paine for every such default or neglect fiue shillings.

It is Ordered that $y^{\mathrm{e}}$ sayd Officers or their Deputyes shal gather 44. Barres or cause to be gathered $\mathrm{vp}$ and safely kept all manner of gates, and gates to Railes, postes, barres and other engines $\mathrm{w}^{\text {ch }}$ now doth belonge or hereafter shalbe belonginge to this Towne at such time as the sayd things are not needful to be vsed, Except any of them shall happen to be stollen, and shall make a noate of them in writeinge betweene them of every particular, $w^{\text {ch }}$ noate, together with the barres and other Engines shalbe cleliuered to the next chosen Officers vpon their entrance into their Office vpon paine for every barre, post and Raile or other Engine ij. $s$. vj. $d$, ffor the $w^{\text {ch }}$ the nexte chosen ed in the usual places accustomed. Officers shal distraine them, Or els make the sayd gates or other Engines so missing by their not distraininge good at their owne proper costs and charges.

Item, it is agreed that whatsoeuer person, being a Cottager or 46 . For asotherwise haveinge right of Common and hath no Cattle feedinge vpon the Comons in this or their right of Commonage, Shall not be conjoined or charged to do any Layers, as any other Comoners and owners of Cattle are by Equitie enjoyned. Provided that all such Layers and partes wherevnto they shalbe conduced and required shalbe done by the charge and expence of the owners of such Tennements.

It is Ordered that no man shal lay nor cause to be layd any 47 . Against Compose or dunghill vpon the Cowwaie nor vpon any other place annoy the about the fennes or fields whereby to annoy the hiewaies, vpon hie waies paine for every loade so layed, iiij. $d$.

If is Ordered that no person or Heardsmen belonging to this Towne shall receiue to keepe or take in charge any Cattle of the Inhabitants of Westwicke, vpon paine for every beast so kept, iij. s. iiij. $d$.

45. Officers to preserue the Town goods and Implements. soilement of any Comoner being a Tennant onely and keepeth no cattle. dunghills.

48. The herdsmen forbidden to take in any cattle of Westwicke. 
It is Ordered that every person whatsoeuer haueinge any Cattle that shal happen to dye in the limmits and boundes of Cottenham, shal take such order for the burieinge of the carkases of all such 49. The Cattle so dyeinge, presently vpon the takinge off of the hide. owners to pay for And if the heardsmen or any other person shal so burie such burieing of carkase before the owner haue notice thereof, Then the owner of their Cattle that happen to die.

every such beaste shal paie and giue vnto such Heardsmen or other person iiij. $d$.

Provided that every beast be buried foure foote deepe in the ground and be covered ouer about $\mathrm{ij}$. foote thicknes of earth at the leaste. And if any owner doe refuse to paie the sayd iiij. $d$. for buryinge such carkase, he shal forfeit xij. $d$. to be leuied by the Towne Officers.

50. The Officers to leuie the penalties forfeited and to be accomptable for them.

5I. Orders to be published.

52. Officers nominated and chosen for this yeer 1640 by whole consent of the Ordermakers.

It is Ordered that the Towne Officers or other deputyes or one of them shall leuie every paine, sume of money, forfeiture or penaltie as aforesayd and shall make a true and just account of them to the Ordermakers $w^{\text {ch }}$ shalbe assembled in the Scholehouse vpon the xij. daye of January next comminge before ten of the cloke in the forenoone of the same daye.

It is Ordered that these Orders shalbe faire written and published within $\mathrm{xv}$. dayes after the makeinge of them at the charges of the Towne by the discretion of the Offycers, and them to remaine in the hands of the then chosen Officers for the time beinge.

And it is further Ordered that the Towne Officers shal, on Sunday next before the xij. day of January next comminge, Reade or cause to be reade the Names of all the Ordermakers $w^{\text {ch }}$ are to meete together and to be present at the makeinge of the Orders. It is Ordered and hereby condiscended and agreed by all or the greater number of the Ordermakers that Thomas Lovell and John Wright shalbe defended to determinate and execute the place of Towne Officers to see the Artycles in the Composition duely performed and these Orders here sett downe, obserued and kept : And if the said Officers shal make default herein, or of the makeinge of their true Accounts of all their Receipts and disburcements in writeinge wholly and joyntly togeather, and the same to 
reade or cause to be read vnto and in the presence of the Ordermakers or the greater number of them $\mathrm{w}^{\text {ch }}$ shalbe then present and assembled vpon the xij. daye of January, they shalbe pained in the summe of iij. $l i$. vj. $s$. viij. $d$. to be leuied by the next chosen Officers.

And further that John Phillip and William Ivatt are chosen to be ffieldreeues By consent and agreement of vs the Ordermakers whose names are vnder written.

[no names appear in this Copy.] 


\title{
E X T R A C T
}

\author{
FROM THE DECISION OF DR. EDEN, VICAR \\ GENERAL OF THE BISHOP OF ELY IN THE CASE \\ BETWEEN THE EXECUTORS OF DR. MAW \\ RECTOR OF COTTENHAM AND \\ WALTER MALE IN REGARD \\ TO SUBSTRACTION \\ OF TITHE.
}

Pronuntiamus Eundemque Walterum Male anno domini 1622 mensibusque in eodem concurrentibus, necnon anno domini 1623 mensibusque in eodem concurrentibus, necnon anno domini 1624 mensibus eodem concurrentibus et eorum annorum quolibet annuatim habuisse et possedisse infra parochiam de Cottenham predicta finesque limites ac loca decimalia eiusdem has res decimales et iure ecclesiastica que sequuntur in schedula proximo sequenti ad valorem etiam siue valores annuatim et quolibet annorum predictorum se extendentes et extendisse iuxta confessionem prefati Walteri Male in hac parte iudicialiter factam pronuntiamus, decernimus et declaramus viz ${ }^{\mathrm{t}}$

The first schedule.

Imprimis 70 loads or Carryes of hey every such load or carrye worth viij. $s$.

Item 9 Calues euery Calf worth $9 s$.

Item 50 Lambes every Lamb worth $4 s$.

Item 60 fleces of woolle euery fleece of woolle worth 1 s. $4 d$.

Item for oblacions at Easter for himselfe or his wife $2 d$.

Item tenn Bushells of Aples one Bushell of Peares, one Bushell of damsins and other plomes euery such bushell of Apples one with another worth xij. $d$. every busshell of damsins and other plomes worth iiij. $d$., fortie Piggs euery pigge worth xij. $d$. 
Necnon eundem Walterum Male habuisse et possedisse infra parochiam de Cottenham predicta finesque limites ac loca decimabilia anno domini 1625 et mensibus in eodem concurrentibus has res decimales ac iura ecclesiastica que sequuntur in hac secunda schedula, ad valorem etiam siue valores in dicta secunda schedula mencionata se extendentes et extendisse, iuxta confessionem prefati Walteri Male in hac parte, iudicialiter pronuntiamus, decernimus et declaramus.

\section{The second schedule.}

Imprimis 70 loads or carryes of hay euery such load or cary of hay worth viij. $s$.

Item 12 Calues euery Calfe worth $9 s$.

Item 50 Lambes euery Lamb worth $4 s$.

Item 60 fleeces of Woole euery fleece worth j. s. $4 d$.

Item oblacions at Easter for himselfe or his wife 0s. ij. $d$.

Item tenn Bushells of Apples, one bushelle of Peares one Bushell of damsins and other plumes euery such Bushell of Apples one with another worth xij. $d$. euery Bushell of damsins and other plomes worth iiij. $d$.

Item 40 piggs euery pigge worth $\mathrm{xij} . d$.

Eundem igitur Walterum Male in summa xix. ti. xij. s. ij. $d$. pro decimis et iuribus Eccleciasticis libellatis ac ad prefatam schedulam xix. $t i$. xij. s. ij. $d$. iuxta propriam ipsius confessionem vero calculo siue raciocinio rite adhibito se extendentes, videlicet.

Imprimis for tyth hay

ti. s. $\quad d$.

Item for tyth Calues

2 .. 16 .. 0

$0 . .8$.. 1

Anno domini

Item for tyth lambs

$1 . .0$.. 0

Item for tyth woolle

0 .. 8 .. 0

Item for oblacions for him selfe and his wife

$0 \ldots \quad 0 \ldots 2$

Item for tyth Apples

0 .. $1 . .0$

Item for tyth Peares

0 .. $0 . .1 \mathrm{ob}$.

Item tyth plomes

0 .. $0 . .0 q$.

Item for Tith piggs

0 .. 4 .. 0 
Anno domini Imprimis for tyth hay

1623 Item for tyth Calues

Item for tyth lambes

Item for tyth woolle

Item for oblacions for himselfe and his wife

Item for tyth Apples

Item for tyth Peares

Item for tyth plomes

Item for tyth pigges

Anno domini Imprimis for tyth hay

1624 Item for tyth Calues

Item for tyth lambes

Item for tyth woole

Item for oblacions for himselfe and his wife

Item for tyth Apples

Item for tyth Peares

Item for tyth plomes

Item for tyth Piggs

Anno domini Imprimis for tyth hay

1625 Item for tyth Calues

Item for tyth lambs

Item for tyth woolle

Item for oblacions for himselfe and his wife

Item for tyth Apples

Item for tyth Peares

Item for tyth Plumes

Item for tyth piggs ti. s. d.

2 .. 16 .. 0

0 .. 8 .. 1

1 .. 0 .. 0

0 .. 8 .. 0

0 .. 0 .. 2

0 .. 1 .. 0

0 .. 0 .. 1 ob

0 .. $0 . .0 q$.

0 .. 4 .. 0

2 .. 16 .. 0

0 .. 8 .. 1

1 .. 0 .. 0

0 .. 8 .. 0

0 .. 0 .. 2

0 .. 1 .. 0

0 .. 0 .. $1 \mathrm{ob}$.

0 .. $0 . .0 q$.

0 .. 4 .. 0

$2 . .16 . .0$

0 .. 10 .. 8

1 .. 0 .. 0

0 .. 8 .. 0

0 .. 0 .. 2

0 .. 1 .. 0

0 .. 0 .. 1 ob.

0 .. $0 . .0 q$.

0 .. $4 . .0$

Unacum expensis legitimis exparte prefatorum Leonardi Maw Thome Burwell et Nicholai Maw factis et faciendis eisdemque seu parti siue cum parte principali predicto, videlicet, prefatis summa xix. $t i$. xij. s. ij. $d$. soluenda etiam condemnando condemnamus per 
hanc nostram sententiam diffinitiuam siue hoc nostrum finale decretum quam siue quod ferimus et promulgamus in his scriptis Taxacionem vero siue (sic) earundem nobis aut alii judici in hac parte competenti cuicunque reseruando reservamus.

Lecta et lata $12^{\circ}$ Martii 1630

Tho : EDEN.

Examinatur et Concordat cum Originali

Ita testor Titus Tilett

Notarius Publicus Actuarius. 


\section{AN ACCOUNT \\ OF THE TITHING OF CATTLE, ${ }^{1} \&$ c.}

Cows, \&c. For every Milch-Cow Two Pence instead of the Tithe Milk, and for a Heifer of the first Calf, Three Half-pence.

Calves. For Calves, if they have any, Six or under, and sell them, the Tenth Penny is due; if they wean them, pay a Half-penny apiece : but if they have Seven or above, under Ten, a Tithe Calf. And then the Parson is to give back Half-pence apiece for so many as wants of Ten : if just Ten, a Tithe Calf ; the last of Ten to be the Tithe Calf, or of Seven Eight or Nine. If it chance that a Man kill a Calf in his house, then to pay for the Tithe thereof a Penny, to be reckoned and made even at Easter, without driving any of them to another Year.

Foals. For Foals, if Seven a Tithe Foal (the Owner to choose Two and the Parson to take his out of the rest at Allhallowtide) allowing to the Owner a Penny apiece for so many as there are short of Ten : and if they have under Seven, and sell all or any of them before Easter following, then to pay for so many as shall be sold the Tenth Shilling. But if they wean them and keep them another Year, a Penny for every Foal; and not drive them to another year.

LAMBS \& SHEEP.

For Lambs, they Tithe them at Shear-Day, the Owner to take two and the Parson the next, and so on for as many as there be, if but Seven he is to give back for what is wanting of Ten, half-pence a piece to the Owner. If a Man has under Seven, and wean them, half-pence apiece; but if they are sold before Shear-Day, the Tenth Penny: if they are sold coupled Ewe and Lamb, before Shear-Day, the Parson to take his Lamb when they are to be had away, and for the Wool Ten Pence the Score. And if any be bought in before Candlemas, and are kept till Shear-Day, then the

1 Compare Article xxvi. This schedule of customary tithe at Cottenham occurs in the printed copy of the Articles of Agreement, but not in any of the written copies. 
Parson is to have his full Tithe. But if after Candlemas, and are sold before Shear-Day, for so many Months as they go, Fourpence a Score. If Sheep be under a Month's feeding, no Tithe is due : but if above a Month, Tithe is due, as above mentioned. If any one remove his Sheep and depasture them in another Parish, what Tithe is due in that Place where they are kept is to be abated out of the Tithe at home.

Tithe-Gozlings, at Seven, Eight, Nine or Ten, and for Chickens Gozlings. a Penny is paid per annum.

For Communicants, every one at Easter Two-pence Oblations CommuniMarried or Single, unless it be a Single Man or Woman born in cants. Town and then they are to pay but a Penny.

For Tithe Pigs, if there be seven of a Litter, the Parson is to Pigs. have One, allowing (as for the Calves) half-pence a piece ; if under Seven the Owner must pay half-pence apiece ; every Litter to be tithed by itself.

For Eggs, every Family five Eggs, if they have any hens ; if no EGGs. Hens a Penny is to be paid.

For Pidgeons the Tenth is to be paid ; as also for Fruit.

Of Hemp the Tenth Sheaf.

Pidgeons.

HEMP.

Of Honey the Tenth Part.

HONEY.

No Tithe of Wood was ever paid in the memory of Man, but Wood. instead, and for Pasturage on the Common, there is a Penny paid called anciently a Plow-Penny.

No Tithe of Hay and Fodder in Smithy-Fen is or hath been HAY. paid in Kind, within the Memory of Man : but there is certain Parcels of the Ground before-mentioned, yearly laid out for the Parson, amounting to the number of Forty Acres, instead of the Tithe of the said Fen; which is likewise exempted therefrom by Virtue of the Composition in the twenty-six Articles. All the antient Inclosures do pay Tithe of Hay in Kind, when they happen to be mown ; but divers late Inclosures are exempted by the Composition, made between the Lords, the Parson and the Tenants; because the Parson hath allotted (instead thereof, and of a Sheep-Walk, and of such other Tithes as have not been usually paid within this 
Parish of Cottenham) an Inclosure of Seventy Acres, besides an ample Improvement to the Parsonage of One Hundred Marks yearly at least in other things and Profits, on account of the said Composition.

Marriage. For Marriage, Fifteen Pence is due to the Parson, and to the Clerk Four Pence.

Christ- For Christning and Churching Eight Pence : if the Child live NINGS.

Burials. till the Woman be Churched; but if it die before, only Two Pence. For Burials, Mortuaries are paid. 


\section{COMMON RIGHTS AT STRETHAM}

EXTRACTS FROM A DECREE MADE BY THE COURT OF EXCHEQUER TRINITY TERM 5 JAMES I CONFIRMING AN AWARD MADE BETWEEN -SIR MILES SANDYS LORD OF THE MANOR OF STRETHAM (CAMBRIDGE) AND THE TENANTS AND COMMONERS OF THE MANOR.

And it is alsoe by this Courte ordered and decreede that every Copieholders Copiholder of a yard land Copihold held of the said Mannor of to plough Streatham his heiars and assignes shall yearelie well and sufficientlie the Lord: plowe, in wheate seede one acre of land once over onelie for the said Sir Myles Sandis, his heires and assignes lords of the said Mannor of Streatham, And in barlie seed one other acre of land once over onelie, and accordinge to that proporcion for every half yard land to plowe half an acre in wheat seede once over onelie, and halfe an acre in Barlie seede once over onelie, and accordinge to a greater or lesse proporcion of Copihold landes which haue byn parte of the yard or half yard lands more or lesse plowinge, They the said Sir Miles Sandis, his heires and assignes, lordes of the said mannor makinge vnto the said Tenantes the vsuall allowances due for the said workes. And the Tenantes of the said Copihold howses or Tenementes which haue byn accustomed for theire said howses or Tenementes to doe certaine workes called pownd Reapes they, theire heires and assignes, shall for ever doe the said workes and in suche manner and sorte as the same haue vsuallie of late byn done the Lordes of the said mannor makinge vnto them the vsuall allowances due for the same, and noe other. And that the said Sir Miles Sandis his heires and assignes Lordes of the said Mannor of Streatham shall haue the foldage in his and theire fold within the said Mannor onelie of such Cottagers sheepe as haue vsuallie folded the same in

Pound

Reapes to bee done by the Tennants to the Lord.
Foldeage of Cottagers sheep in the Lords folde. 
the Lordes Folde and of soe many onelie of the sheepe of such Cottagers as are And ought to be kept by them in the Right of theire Cottages onelie. And that not any other Freehold or Copihold Tenant of the said Mannor, nor any other Owner or Inhabitant within the said Mannor shalbe from henceforth Compellable to fold his sheepe in the Lordes fold, but that it shalbe for ever heereafter lawful to the said Freehold and Copihold Tenantes, and other Owners and Inhabitantes within the said mannor, and to every of them, theire and every of theire heires and assignes, to fold such sheepe as they or any of them maie lawfullie keepe in the Fieldes and Commons of Streatham aforesaid vpon theire or any of theire landes at theire seuerall wills and pleasures, without the Interrupcion of the said Sir Miles Sandis his heires and assignes. And it is alsoe by this Courte nowe ordered and decreede that all

Coppiholders, Tennants and Cottagers quietlie to enjoy their holdes. the Copihold Tenantes and Cottagers of the said Mannor of Streatham theire heires and assignes shall against the said Sir Miles Sandis, his heires and assignes Lordes of the said Mannor of Streatham, for ever heereafter severallie haue hold, and enioy quietlie and without his or theire interrupcion all the land meadowe pasture and marish nowe in the seuerall occupacion of them or any of them or of theire seuerall assignes as parcell or now reckened, accompted, reputed or occupied as parte or parcell of the said seuerall Copiholdes or Cottages yet vnder and subiecte vnto the auncient forfeytures, Conditions, Customes, Dueties and services other then such as are heereafter heerein decreed to be discharged or dispenced withall. And that the said Sir Miles Sandis, his heires and assignes Lordes of the said Mannor of Stretham, shall for ever heereafter be barred vnder colour of demeasne landes to demaund against the said Copihold Tenantes or Cottagers or against Theire heires or assignes anie of the landes, pasture, meadowe, or marishe now by them or any of them, or by theire or any of theire assignes vsed as parcell of the said Copiholdes, or Cottages aforesaid. And that the said Sir Miles Sandis, his heires and assignes Lordes of the said Mannor of Streatham, shalbe from henceforth debarred from all manner of Claime and demaund 
whatsoever vnto the heriottes and Daies workes pretended to be Noe herriots due from anie of the Freehold, or Copihold Tenantes, or Cottagers to be paid to within Streatham and Thetford aforesaid, or from theire or any of heerafter theire heires, or assignes except the Daies workes afore by theise nor daies presents decreed and appointed to be done for the said Sir Myles Sandis, his heires and assignes, by the Cottagers and Copiholders aforesaid. And alsoe it is nowe ordered and decreed by this Courte that the said Sir Miles Sandis, his heires and assignes lordes of the said Mannor of Stretham, shall for ever heereafter be debarred from the demaunding or having anie greater Fine vpon or for the admission of any Copiholder or Cottager within the said mannor to any such Copihold or Cottage, or to any the landes, meadowe, or Marishe therevnto nowe appertaininge or belonginge, or heereafter to be apertaininge or belonginge otherwise then onelie proportionablie after the rate of one yeares value of the Lordes old and vsuall rent of the said Copihold or Cottage, and the landes meadowe and Marishe therevnto nowe belonginge, or heereafter to be appertayninge, whervnto admission is to be made or given, excepting onelie the next Fines due or to be due for or vpon the next admission vnto the Copihold landes, tenementes and hereditamentes alreadie Surrendred or discended, or agreed vpon before the fifteenth daie of May last paste to be heereafter surrendred. And alsoe by this Courte it is ordred and decreede that it shalbe lawfull for the Copiholders and Cottagers of the said Mannor of Streatham, theire and every of theire heires and assignes, to fell and sell theire woodes and Timber growinge vpon anie of theire Copiholdes or Cottagholdes at all times, without demaundinge anye licence therefore of the said Sir Miles Sandis, his heires and holds. assignes lordes of the said Mannor, and without incurringe anie daunger of forfeyture therefore, or for anie other wast Committed or to be Committed by the said Copiholders or Cottagers, theire or anie of theire heires or assignes, vpon theire said Copiholdes or Cottages, except the wilfull pullinge downe of theire Copihold howses or Tenementes and not reedifienge the same within three yeares next after suche pullinge downe, and except alsoe the wilfull

Fine Certaine onelie, due to the Lord.
Power giuen to Coppiholders to sell the trees groweing on their Coppi-

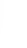


permitting theire Copiholde howses or Tenementes to decay, and to continue in decay vnrepayred by the space of three yeares after notice or warning given by the Lord of the said Mannor for the time beinge or his Bayliffe to the Copihold Tenant or Cottager of the same howses or Tenementes wilfullie permitted to continue in decay, for the repayringe or reedifienge the same. And that it shall be lawfull for all or anie the said Copiholders, and Cottagers Tenantes of the said Mannor, theire and every of theire heires and Lawfullness assignes, from time to time and att all times heereafter, at his and for Coppiholders to lett their Coppiholds. theire pleasures, to demise his or theire sayd Copiholdes and Cottages, or anie parte thereof for the tearme of one and twenty yeares or vnder vnto such persons as the said Copiholder or Cottager shall thinke fitt without incurringe any forfeyture therefore, soe that the said Copiholder soe demisinge his said Copihold or Cottage, or anye parte thereof, at the Courte of the said Mannor of Streatham next followinge the said demise, or within one yeare next after such demise, doe paie or cause to be paid vnto the Lord of the said Mannor for the time beinge or to his Bayliffe proportionablie after the rate of one yeares value onelie of the lordes old and vsuall rent of the said Copihold or Cottage soe demised, or wheareof anie parte or parcell shalbe soe demised, for and in the name of a Fine.

Sir Miles to common for purchased houses as other inhabitants and not otherwise.

Sir Miles tyed to the Orders and bylawes of Stretham as well as others.
And that if the said Sir Miles Sandis his heires or assignes shall at anie time heereafter acquire purchase or haue anie landes, Tenementes or hereditamentes in Stretham and Thetford aforesaid, nowe held occupied or enioyd by anie the Tenantes, Owners Inhabitantes or Comoners aforesaid, that then he the said Sir Miles Sandis his heires and assignes shall in regard thereof haue such like interest lottes, partes, Commons, benefittes, and comodities onely and noe other nor otherwise in the said Fennes called Thetford Hall Fenne and Grvnty Fenne, and in the said sixteene hundred acres to be assigned as aforesaid, then as the Owner or Owners of the same enioyd, or rightlie might haue enioyd, by the Orders and Bylawes within the said mannor of Stretham, And that 
for and concerninge such interest, lottes partes, Comonage, benefittes and Comodities as shall within the said Mannor of Stretham appertaine or belong to the landes, Tenementes, or Hereditamentes by him the said Sir Miles Sandis, his heires and assignes, heereafter purchased, he the said Sir Miles Sandis, his heires and assignes shalbe stinted, ordered and directed in like sorte as other Tenantes of the said Mannor by the Bylawes and orders heereafter to be made within the sayd Mannor of Stretham for the stintinge, orderinge, directinge, governinge or severinge of the said growndes and Commons heerin allotted vnto the now said Complainantes and other the Tenantes, Owners and occupiers in Stretham and Thetford aforesaid, Vnlesse the same be altred by a generall assent and consent of the said Sir Miles Sandis, his heires and assignes, and of all the Tenantes, Owners, Inhabitantes and Comoners aforesaid. And this Courte doth alsoe order and decree that the said Sir Miles Sandis, his heires and assignes, at all and every time and tymes heereafter maie lawfullie and quietlye without the lett, trowble, disturbance or deniall of the said nowe Complainantes or other the Tenantes, Owners, Inhabitantes, and Comoners aforesaid or of any of them, or of the heires or assignes of them or of any of them, fence, ditche, and in severall inclose all the arrable landes, meadowes, and landes endes of him the said Sir Miles Sandis his heires or assignes lyinge in the Fields of Stretham, or asmuch thereof as shall seeme good vnto him or them, in which arrable landes, meadowes, and landes endes, and in everye parte thereof soe inclosed, the said nowe Complainantes and other the Tenantes, Owners, Inhabitantes and Comoners aforesayd, and the heires and assignes of them and of every of them, are to be barred and excluded of and from all manner of Comonages and depasturinge sheepe or cattle; and immediatelie vpon the incloasure of anie parte thereof as aforesaid, the said Sir Miles Sandis his heires and assignes are for ever to be barred and excluded from Keepinge anye cattle whatsoever as Lordes of the said Mannor of Stretham within anie the Comon arable fieldes or Common waies or Comon meadowes adioyning to the Comon Arrable Feildes of Streatham aforesaid not inclosed.

A supposition of Orders and Bylawes to I. Stint. 2. Order. 3. Direct. 4. Gouerne. 5. Seuer.

Consent for alteration most not bee of a major part onelie but generall.

Sir Miles his power to enclose his arable.
Uppon enclosure of his arable land, Sir Miles is to lose sheep common. 
An acre to be allowed in leiw of the house and ground where now Jer. Townsend liues as ferriman. March 22. 1637.

Priueledg of ferriage.

F

\section{at}

Sir Miles and his heyres for ever excluded from all the proffit of the 1600 acre as Lords.

Sir Miles to haue noe stroake or claime in anie after subdiuision.

And that yt shalbe lawfull for the said Sir Miles Sandis his heires and assignes to erecte and hold one Cottage or Cote to be at the newe intended Ferry, not takinge therefore above one acre of grownd, allowinge for the same one other acre of like land and of like condicion in some other place, and likewise allowinge to the Tenantes, Owners Inhabitantes and Comoners in Streatham and Thetford aforesaid such freedome and priveledge of the Newe intended Ferry for the price of the ferriage of themselues, theire families, servantes and cattle over the River from the one side of the newe intended Ferry vnto the other side thereof, as they haue heertofore enioyd at the old Ferrye. And this Courte doth alsoe order and decree that the said Sir Miles Sandis his heires and assignes shall, with asmuch speed as convenientlie may be, assigne, measure, and sett ont the sayd sixteene hundred acres heerby before allotted vnto the said Nowe Complainantes and other the Tenantes, Owners, Comoners and Inhabitantes of Streatham and Thetford aforesaid, and from and after the sayd measure and assignement that he the said Sir Myles ISandis, his heires and assignes as Lordes of the said Mannor of Stretham, (except in Cases provided as aforesaid) shalbe vtterlye barred and secluded for ever from takinge of anie Commonage or other profitt whatsoever by feedinge, mowynge, ditchinge, agistinge or improvinge in or out of the said sixteene hundred acres and in or out of the said Thetford Hay Fenne alias Thetforde Hall Fenne, and in or out of the after pasture of the aforesaid seuerall meadowes of Ellford and the aforesaid several meadowes or marishes in Hole Fenne (except before excepted).

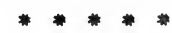

And yt is alsoe ordered and decreed by this Courte, at the desire of the nowe Complainantes by theire said Bill, and with the assent of the Nowe defendant within the said Towne in his said answeare, that if the now Complainantes and the Tenantes, Owners, Comoners and Inhabitantes of both the said Townes of Streatham and Thetford shall heereafter sue vnto this Courte for an equall subdevision of the said sixteene hundred acres to be made betweene every of 
them, that then he the said Sir Miles Sandish, [h]is heires and assignes Lordes of the said Mannor of Streatham, shall yeald his and theire assent thervnto, and that in the meane time vntill such subdivision shalbe, that parcell of the said sixteene hundred acres called Hole Fenne Lazer and Chaire Fenne plaines shalbe yearelie preserved to be Mowen and devided amongst the Tenantes, Owners and Comoners of both the said Townes of Streatham and Thetforde, accordinge to the Custome heertofore vsed; and that soe muche of the said sixteene hundred acres as lyeth betweene Barlake and Snowte ditche shalbe fedd onelie with the Milche Kine and weanelinge Calues of the Tenantes, Owners, Comoners and Inhabitantes within the said Towne of Streatham, from the Feast of $S^{\text {ct }}$ Mathias the Apostle in every yeare vntill all the harvest of the sayd Towne of Streatham be fullie ended; and that parcell of the said sixteene hundred acres called Stallocke and soe much of the said Fenne called Haie Fenne as shall be comprised within the said sixteene hundred acres yearelie from the Feast daie of the Annunciacion of the blessed Virgin Marie vntill the full end likewise of the said harvest shalbe fedd onelie with theire Workinge horses, and that noe sheepe shalbe fedd or kept upon the sayd growndes in anie yeare betweene the said Feast Daie [of the Annunciacion of the blessed Virgin Marie and the feast day $]^{1}$ of $S^{\text {ct }}$ Andrewe the Apostle. And lastlie it is ordered and decreed by this Courte that the greater parte of the Comoners of each of the said two Townes of Streatham and Thetford respectivelie shall and maie from time to time have power and authoritie, without the assent or intermedlinge of the said Sir Miles Sandis his heires or assignes Lordes of the said lawes. Mannor, to make Orders and Bylawes for and towching the feedinge of such Fenne growndes as are in or by this order and decree severallie allotted to each of the said Townes. And that to and for the keepinge and performinge of such orders and Bylawes soe to be made, not onelie the makers of and assenters vnto the said Orders and Bylawes, but alsoe all the other Comoners of both the Townes are tyed and bound by the decree of this honourable Courte.

1 These words omitted, but supplied from the certified copy. 
Fanshawe

Termino : Pascae Jacobj $11^{\circ}$

\section{A COPPIE OF AN AFFOEDAUIT \\ MADE BEEFORE THE BARONS OF \\ THE EXCHEQUER. ${ }^{1}$}

Cant.

Memorandum quod Mich: Flud de Stretham clerke et Tho: Frankham de Thetford infra Insulam Eliensem in comitatu Cantebrigie venerunt coram Baronibus Scaccarij $\mathbf{x x v}^{\text {to }}$ die Maij hoc termino in proprijs personis et sacrum suum præstitere corporale in his Anglicanis verbis sequentibus viz :

That whereas within the Commons and common Fenn grounds of Stretham and Thetford aforesaid the Commoners and Inhabitants of each towne respectiuelie haue had libertie, and of right ought to haue libertie, of feeding and depastureing their workeing horses and workeing mares. Now these deponents say that by reason of libertie giuen to the greater part of either towne abouesaid respectiuelie by an order or decree made in this Courte, in Trinitie terme Anno $5^{\circ} \mathrm{Jacobj}$, giueing power to make bylawes, the commoners and inhabitants of Stretham and Thetford aforesaid are debarred of their auncient libertie by a bylawe made by the greater part whereby the Commoners of Stretham are not allowed to keep a sufficient and competent number of workeing horses or workeing mares there. And the Commoners and inhabitants of Thetford aforesaid haueing libertie to feed as aforesaid are, by a bylaw latelie made, vtterlie debarred and excluded from keeping. anie manner of workeing horses or workeing mares vppon those commons, where by auncient custome and by right they ought to bee kept, whereby the arable lands of Thetford aforesaid especiallie lie vntilled and the corne now groweing within the sayd feilds not like to bee preserued in due time at haruest for want of workeing horses and workeing mares for the necessarie vses of the commoners of each towne aforesaid. Soe, \&c.

Præstitere sacramentum suum 25 die Maij 1609.

Geo : SNYGG,

${ }^{1}$ Originally written "to bee made beefore a master of Chancerie," and altered as above. 


\section{ORDERS SET DOWNE}

THE 28 OF JUNE I609 BY SIR MILES SANDYS, SIR RICHARD COX KNIGHTS AND JEAMES TAYLOR DOCTOR OF DIUINITIE FOR THE INHABITANTES OF STRETHAM WITHIN THE ILE OF ELIE AND COUNTIE

\section{OF CAMBRIDG CONCERNING THE VSAGE OF}

THEIR COMMON IN STALLOCK AND HAY-

FENN WITH THEIR WORKEING HORSES

AND WORKEING MARES BY VERTUE

OF A COMMISSION TO VS AND

OTHERS DIRECTED OUT OF

HIS MAIESTIES COURT

OF EXCHEQUER FOR

THAT PURPOSE. ${ }^{1}$

First it is ordered by the sayd Commisioners that the sayd 5. workeing inhabitants within the towne of Stretham or the precincts thereof haueing anie auncient commonable messuage or Tenement shall and may, by right of his or hir sayd messuage or Tenement, yearlie commonable depasture in the sayd Commons fiue workeing horses or mares with their foales, soe they bee of his or hir owne proper goods and at such times of the yeer onelie as hee or shee of right beefore this order might haue done, for the bringing home of fother and turffs for his or hir provision.

Item, it shalbee lawfull for anie of the said inhabitants, haueing 6. horses for an auncient Commonable messuage or tenement as is aforesaid wherewith hee or shee vseth in tillage within the Mannor of Stretham to the number of fifteen acres or vnder, to depasture one

1 No doubt this Commission was the result of the complaint made by Michael Fludd and Thomas Frankham, 25 May 1609, as to the insufficient number of working horses allowed to be fed on the Commons. See p. 260. 
workeing horse or mare with hir foale aboue the number of fiue in the Commons aforesaid of his or hir owne proper goods and in manner aforsaid, and that by right of his or hir said messuage or 7. for tenement. And for him or hir that vseth in tillage as aforesaid to 30 acres. the number of 30 acres, to depasture two workeing horses or mares with their foales aboue the sayd number of fiue in the Commons aforesaid of his or hir owne proper goods and in manner aforesaid 8. for by right of his or hir said messuage or tenement. And for him or 45 acres. hir that vseth in tillage as aforesaid to the number of 45 acres, to depasture three workeing horses or mares with their foales of his or hir owne proper goods aboue the said number of 5 in the commons aforesaid and in manner aforesaid by right of his of hir

9. for 60 acres.

Parson to keep 3 horses or mares more than anie man. said messuage or Tenement. And for him or hir that vseth in tillage as is aforesaid to the number of 60 acres, to depasture fower workeing horses or mares with their foales of his or hir owne proper goods aboue the said number of fiue in the Commons aforesaid and in manner aforesaid by right of his or hir said messuage or tenement.

Item, it shalbee lawfull for the Parson of Stretham for........... in regard of getting in his harvest within the Mannor........... to haue and depasture yeerlie in the said Commons........... aboue the rates aforesaid three horses or mares with their foales of his owne proper goods and in manner aforesaid, by vertue of his Parsonage house being a Commonable house.

Lastelie, that noe man shall presume to exceed the rates afore set downe or disturbe anie Comoner in keeping accordeing to the rates aforesaid vntill it shalbee otherwise ordered in his Maiesties Court of Exchequer.

Miles Sandys. R. Cox. James Taylor. 


\section{ORDERS SET DOWNE}

THE 28 OF JUNE I609 BY SIR MILES SANDYS, SIR RICH. COX, KNIGHTS, AND JAMES TAYLOR DOCTOR OF DIUINITIE FOR THE INHABITANTES OF THETFORD WITHIN THE ILE OF ELIE AND COUNTIE For Thetford

OF CAMBRIDG, CONCERNING THE VSEAGE OF Goldsmore.

THEIR COMMON IN GOLDESMORE VNDE-

UIDED WITH THEIR WORKEING HORSES

AND WORKEING MARES BY VERTUE

\section{OF A COMMISSION TO VS AND}

OTHERS DIRECTED OUT OF

HIS MAIESTIES COURT

OF EXCHEQUER FOR

THAT PURPOSE.

First it is ordered by the said Commissioners that euerie inhabi- 3 . horses, tant within Thetford or the precincts thereof, haueing anie auncient Commonable messuage or tenement, shall and may, by right of his or hir messuage or tenement, yeerlie depasture in their said Commons three workeing horses or workeing mares with their foales, soe they bee of his or hir owne proper goods and at such time of the yeer onelie as hee or shee of right in former times beefore this order might haue done, for the bringing home of fother and turff for his or hir owne prouision.

Item, \&c. [This section is similar to the corresponding section 4. for of the rules made for Stretham, except that there is no reference to any holding of more than 45 acres, "which number noe commoner doth now exceed."]

Item, it shalbee lawfull for the Lord of Thetford or his fermor by 45 The Lord to right of his mannor house, beeing an auncient commonable meskeep 5 . suage, to depasture two workeing horses or mares with their foales 
in the commons aforesaid and in manner aforesaid aboue the said number of three, in regard hee hath euer of olde been allowed a greater proportion both of moweing and feedeing within the Commons then other commonable houses.

Lastelie noe man shall presume to exceed the rates afore sett downe, beeing verie sufficient for all sortes, they haueing beesides. verie good entercommons to put in their workeing horses and mares, nor to disturbe anie commoners in keeping accordeing to the rates aforesaid vntill it shalbee otherwise ordered in his Maiesties Court of Exchequer.

Myles Sandys. R. Cox. James Taylor. 


\section{CERTAINE ORDERS,}

BYLAWES AND PAYNES MADE BY THE LEETT HOLDEN AT STRETHAM THE 29 OF APRILL $A^{\circ}$. DOJ. 1614 WITH CERTAYNE ORDERS AND BYLAWES

MADE AND AGREED UPON BY THE COURT LEET AND ALSOE THE COURT BARON HOLDEN AT STRETHAM AFORESAID WITHIN THE ILE OF ELIE AFORESAID THE DAY AND YEER ABOUEWRITTEN.

1. Imprimis wee finde Thomas Egnie faultie in that hee hath not scoured his drayne, and therefore wee doe payne him to amend it by the 10th of May next comeing in, iij. s. iiij. $d$.

2. Item, there standeth a wall uppon the common where Richard Sheirbrooke dwelleth, and wee doe enjoyne him to put it downe by the 10th of May nexte, in payne of 5 s.

3. Item, wee finde that the chimney where widow Salmon dwells is in default, and wee doe payne hir to amend it by the 15 th of May next, in payne of 20 s.

4. Item, wee finde that Francis Barker hath cast up a ditch from clay lakes end vnto Elford which is a great annoyance to our Heard, and wee doe enjoyne him to throw it or cast it in agayne by the 12 th of May next comeing, in payne of $5 \mathrm{li}$.

5. Item, wee order and appoynt that noe man woman or childe shall sett anie nett or netts in anie of our common lakes or ditches after sunn bee downe halfe an howre, in payne for euerie default soe proued, iij. s. iiij. $d$.

6. Item, wee find that John Ramsies chimnie is in default and wee doe payne him to amend it within 10 dayes in the summ of 10 s.

7. Item, wee finde Richard Sheirbrooke dwelleth vppon a ground 
encroached vppon the common and therefore wee payne him to amend it within 14 dayes in 40 s.

8. Item, we finde Christopher Isacson hath taken in to his house one Robert Webb and wee payne him to auoyd him by Whitsontide next comeing or to put in securitie to discharge the towne, to the constables and churchwardens for the time beeing, in $\mathrm{x} . l i$.

9. Item, wee finde George Wells is taken into the towne by Wm. Piggott and wee payne him to auoyde him by Whitsontide next or to put in securitie to discharge the towne, to the constables and churchewardens for the time beeing, in payne of $10 \mathrm{li}$.

10. Item, wee agree that euerie man shall make his part sufficientlie in the pound wall yeerlie and euerie yeer within 4 dayes warning giuen by the constables or fennreeues vppon payne to forfeit for euerie such default, iij. s. iiij. $d$.

11. Item, wee agree that euerie man shall make his Particular part on the East side of Bar-lake from tyme to tyme within 3 dayes after warning giuen by the fenreeues vppon payne to forfeit for euerie default, iij. s. iiij. $d$. 


\section{ORDERS AND BYLAWES}

MADE AND AGREED VPON BY THE COURT LEET AND ALSOE THE COURT BARON HOLDEN $\Lambda T$ STRETHAM WITHIN THE ILE OF ELIE THE 29th OF APRIL IN THE I 2 th YEER OF THE

REIGNE OF OUR SOUERAYGNE LORD

JAMES BY THE GRACE OF GOD

KING OF ENGLAND E־c. AND

OF SCOTLAND THE $47^{\text {th }}$

ANNO DOMINI I6I4.

1. Imprimis wee order and appoynt that whereas diuers idle Gleaneing. euill disposed persons vnder pretence and colour of glayning doe often times in time of Haruest yeerlie take and carrie away much of the corne and grayne of diuers of the inhabitants of Stretham, by meanes whereof the true owners and occupiers of the aforesaid lands haue not sufficient libertie to suffer their corne beeing reaped, mowed, and shocked in the feilds to haue that wythering and season of the yeare that were requisite. For remedie whereof None to wee appoynt that at noe time or times heerafter it shalbee lawfull for anie person or persons whatsoeuer within the parish of Stretham aforesaid to gleane, perceaue and take anie corne or grayne in and vppon anie part or parcell of the arable or corne feildes beelonging to the mannor of Stretham aforesaid. Nor shall cause or procure anie person or persons whatsoever directlie or indirectlie to gleane, perceaue and take anie corne or grayne in or vppon anie part or parcell of the said arable or corne feildes vntill the Harvest there bee fullie ended, vppon payne to forfeit for euerie such particular default and for euerie time soe gleaneing or offendeing, the somm of fiue shillings, to bee forfeited and leuied Poena $5^{\text {s. }}$. by way of distress of such offenders or such persons who shall procure, abett, or giue entertaynment or harbor to anie such person or persons whatsoeuer so gleaning as is aforesaid. 
None to gleane but vnder 16 or aboue 60 yeers of age.

\section{Poena $5 s$.}

Noe owner to suffer gleaners his land.

Poena 5s.

2. Item, wee order and appoynt that notwithstandeing this order aforesayd it shall and may bee lawfull to and for anie man, woman or childe, beiug vnder the age of 16 yeeres and aboue the age of 60 yeeres, or beeing otherwise sicklie and not able to worke a dayes worke in tyme of Harvest, soe to be adjudged by the Parson and churchewardens for the time beeing, and not haueing vseing or occupieing anie part or parcell of a commonable messuage as aforesaid, to gleane lawfullie anie such scattered corne or grayne as shalbee left by the owner or owners thereof then and after that all the grayne (the gleanings and scatterings onelie excepted) shalbee carried away and not beefore. Soe that such gleaner or gleaners doe not gleane within the bredth of 3 lands of anie corne standeing or lying vncarried, vppon the payne aforesaid to bee forfeited and leauied of the persons aforesaid.

3. Item, wee order and appoynt that it shall not bee lawfull for anie owner farmor or occupier of anie lands within the feilds or limitts aforesaid to suffer or permitt anie person or persons to gleane or gather vppon his or anie of their lands, soe occupied as aforesaid, contrarie to the true intent and meaneing of anie of the orders aforesaid, anie corne or grayne whatsoeuer, vppon payne to forfeit and pay for euerie suche default the summ of fiue shillings, to bee leauied of the offendors goods by way of distress as aforesayd.

Not to gleane 4. Item, wee order and appoynt that it shall not bee lawfull for beefore 8 in the morning after 6 at night. anie person or persons whatsoeuer to gather or glayne anie scattered corne or grayne in and vppon anie part or parcell of the arable or corne feilds beelonging to the Mannor of Stretham aforesayd beefore the houres of 8 of the clock in the aforenoone daylie and euerie day in time of harvest yeerlie, nor after the howres of sixe of the clock in the afternoone daylie and euerie day Poena 5s. yeerlie, vppon payne to forfeit and pay for euerie such particular default, the summ of fiue shillings of lawfull monie of England, to bee leauied and taken by way of distress out of all or anie the offenders goods : Or otherwise to bee leauied or taken by way of distress out of all or anie the goods or chattels of anie person or 
persons who shall procure or suffer abett or giue entertaynement to anie such gleanor or gleanors as aforesaid.

5. Item, wee order and appoynt that it shall not bee lawfull for None to anie person or persons whatsoeuer to gleane, take, or gather anie raynie scattered corne or grayne within anie part or parcell of anie the weather. arable lands within the liberties of Stretham aforesaid at noe unreasonable tyme or tymes (that is to say) when as by reason of rayne or anie other unseasonable weather the corne and grayne beeing within the feilds of Stretham aforesaid is not in good case or meet, or fitt to bee carried home by the owners thereof, soe to bee adjudged by the Parson or his sufficient deputie for the time beeing, vppon payne to forfeit and pay for euerie such particular Poena ros. default the summ of tenn shillings of good and lawful monie of England to be leauied and taken by way of distress out of all or anie of the offendor or offendors goods or chattells or to be leauied and taken out of all or anie the goods or chattels by way of distress as aforesaid of anie person or persons who shall procure suffer abett, giue harbour or entertaynment to anie such gleanor, or gleanors as aforesayd.

6. Item, wee order and appoynt that it shall and may bee lawfull for the Parson of Stretham for the tyme beeing, or his sufficient deputie or deputies, or for anie owner, farmor or occupiers of anie arable lands within the fields and lymitts of Stretham aforesaid to collect, leauie and take all or any the summ or sommes of monie by way of distress as aforesaid and being payable as aforesaid.

And to render and give vp the moyetie and one halfe thereof onelie to the Lord of the mannor of Stretham aforesaid or to his bayliff for the time beeing within six dayes next after anie such some or somes of monie shalbee had and recouered as aforesaid.

And the other halfe or moyetie thereof all charges and expences of the law if anie shall happen beeing first deducted to take and convert to his or their owne proper and priuate vse or vses anie thing in this order notwithstanding.

7. Item, wee order and appoynt that its hall not bee lawfull for None to giue anie person or persons haueing or which shall haue anie Pease or gather Pease 
without sendeing one of his house with them.

None to gather Pease without a Deputie.

Parson or owner to take away gleanes.
Beanes groweing in anie of the feilds of Stretham aforesaid to procure, suffer or give leaue to anie person or persons whatsoeuer to take or gather anie pease or beanes in or vppon anie of his or their land or lands within the feilds aforesaid. Except that euerie such person or persons, soe haueing Pease or beanes groweing as aforesaid, shall first procure and send one of his owne familie to bee continuallie present with such person or persons to whom hee shall giue or graunt such leaue to gather as aforesaid soe long Poena 5s. as anie such person shalbee gathering, vppon payne to forfeit and pay for euerie time soe offendeing the summ of fiue shillings, to bee leauied by way of distress as aforesaid and to bee collected as aforesaid.

8. Item, wee doe order and appoynt that if anie person or persons whatsoeuer shall at anie time heerafter take or gather anie pease or beanes in or vppon anie land or lands of anie person or persons within the feilds and limitts aforesaid and not haueing his or their sufficient deputie or deputies beeing one of his owne familie soe present as formerlie is appoynted, then euerie such person or persons soe offendeing and all and euerie other person or persons who shall procure, abett, giue harbour or entertaynPoena 5s. ment to anie such offendor as aforesaid shall forfeit and pay for euerie such particular default and for euerie time soe offendeing, the summ of fiue shillings, to bee forfeited and leauied by way of distress as aforesaid and to bee collected as aforesaid.

9. Item, wee order and appoynt that if anie person or persons whatsoeuer shall at anie time heerafter gleane, perceaue and take anie corne or grayne whatsoeuer within the limits of Stretham aforesaid contrarie to anie of the orders heerin mentioned, then it shall and may bee lawfull for the Parson of Stretham or his deputie or anie owner, farmour or occupier of anie arable lands beeing within the limits of Stretham aforesaid to take away all such gleaned corne which shalbee soe gleaned or vehementlie suspected and adjudged to bee soe gathered or gleaned contrarie to anie of the orders aforesaid, and the same soe taken away to scatter abroade to anie of the shocks next adjoyneing of that 
kinde of grayne or otherwise to dispose of at his or their owne best likeing.

10. Item, wee finde that wortt loade is not sufficientlie scowred Defaults. and clensed and wee doe order and appoynt that Francis Barker Wortloade. the now farmor thereof shall clense, rooke, haffe and scowre the same from side to side at the full bredth thereof, as it vsuallie hath been or ought to haue been, beefore the last day of May next comeing ; And soe keep it clensed, rooked, haffed, and scowred, vppon payne to forfeit and pay the summ of fiue poundes. And that euerie other person which shall at anie time heerafter haue, houlde, occupie, vse, or enjoye the aforesaid Loade called wortt loade shall likewise clense, rook, haff and scowre the same from side to side at the full breadth and soe keep it continuallie from time to time and at all times heerafter, vppon like payne to forfeit and pay the summ of fiue pounds as aforesaid of good and lawfull monie of England.

11. Item, wee finde that there hath been heertofore auncientlie a Long-lake. load or drayne from the new coate now called Barkers coate which leadeth through the cowpasture and horsepasture and soe in to Hay fenn and from thence into the lake called long lake beeing within the 100 acres which vsuallie hath been heertofore clensed and cast by the inhabitants of Stretham vnto long lake, aforesayd and therefore wee order and appoynt that the sayd loade or drayne leadeing from Barkers coate as aforesaid to the lake called long lake shalbee by the inhabitants of Stretham aforesaid scowred, haffed, clensed and cast in such bredth as it shalbee sett out and thought fitt to bee done by the constables of Stretham aforesaid, accordeing to the custome of the mannor aforesaid, beefore the last day of Julie next comeing, vppon payne to forfeit and pay the summ of fiue pounds. Soe that Sir Miles Sandys knight will make the like drayne thorough the 100 acres.

12. Item, it is ordered by the said Jurie that if anie person or persons inhabiting within the towne and limitts of Stretham shall refuse or neglect to doe such worke and works for the scowring and clenseing of the aforesaid draynes, beeing sett out 
and thought fitt to bee done by the constables as is aforesaid, as hee or they ought to doe, and beeing therevnto warned by the constables aforesaid accordeing to the custome of the said Mannor, that then euerie person soe offendeing shall forfeit and pay for euerie pole and soe after the rate of a greater or lesser proportion soe sett out for him to doe and not perfited and sufficientlie done accordeing to the appoyntment and likeing of the constables aforesaid by or beefore a certayne day which the constables shall then limitt and appoynt, the summ of tenn shillings of good and lawfull monie of England.

13. And for that the neglecting or refuseing of the scowreing clenseing or ditching of anie part of the aforesaid drayne may bee verie prejudiciall and hurtful to diuers of the inhabitants aforesaid who shall well and sufficientlie scowre and clense their parts, accordeing as it shalbee by the said constables aforesayd appoynted; Therefore wee order and appoynt that it shall and may bee lawfull for the constables for the time beeing to collect and gather by way of distress the aforesaid summ of 10 s. of euery person or persons who shall soe neglect or refuse to doe and perfitt his or their part or parts, accordeing to the day and manner thereof, as it ought to haue been done, and the monie soe collected and gathered or soe much thereof onelie as shalbee fitt and necessarie to bee imployed in and about the aforesaid business shalbee by the constables aforesaid vsed and imployed in the makeing or mending such places neglected as aforesaid. And the ouerplus thereof to their own proper vse or vses.

14. Item, wee finde that a lake called thorough lake, beeing an auncient drayne or Sewer, is not sufficientlie scowred and clensed. And wee order and appoynt John Coateman the elder now owner thereof shall clense, rook, haff, and scowre the same from side to side at the full bredth thereof, as it vsuallie hath been done or ought to haue been done, beefore the last day of May next comeing And soe keep it clensed, rooked, haffed and scowred vppon the payne to forfeit and pay the summ of fiue pounds of good and lawfull monie of England. And that euerie other person 
which shall at anie time heerafter haue, hold, occupie, vse, or enjoy the aforesaid Lake called Thoroughout lake shall likewise clense, rook, haff, and scowre the same from side to side at the full bredth and soe keep it continuallie from time to time and at all times heerafter, vppon the payne to forfeit and pay the somm of fiue pounds aforesaid of good and lawfull monie of England.

15. And whereas the Inhabitants of Stretham aforesaid haue heertofore to their great charge Banked much of their cowpasture and horsepasture for the better preservation thereof to bee kept from invndation and ouerfloweings of water which often times doe happen, Therefore wee doe order and appoynt that if the constables of Stretham aforesaid shall appoynt and sett downe by publique warning giuen by them, or otherwise by priuate warning ouer night, anie common dayes workes for the keeping, mayntayning, or amendeing of all or anie the aforesaid Banks or for the new makeing of any banks within anie other part of the cowpasture or horsepasture aforesaid ; Or shall otherwise lay out and appoynt the same to bee done by lotts and parts, Then euerie such person or persons soe refuseing or neglecting to doe his or their part or parts, soe sett out and thought fitt to bee done by the constables aforesaid accordeing to the custome of the mannor aforesaid, shall forfeit and pay for euerie pole and soe after the rate of a greater or lesser proportion soe sett out for him or them to doe and not perfited and sufficientlie done accordeing to the appoyntment and likeings of the constables aforesaid, the summ of 10s. of good and lawfull Poena ros. monie of England, to bee leauied and taken by the constables of the goods of such offendors and to bee employed as formerlie is appoynted. And that euerie person or persons who shall refuse or neglect to doe his or their common dayes worke or workes, beeing thereunto warned as aforesaid, or shall not procure or send a sufficient person in his roome or stead from time to tyme and at all times heerafter soe to bee adjudged by the constables for the time beeing, then euerie such person or persons soe offending shall forfeitt and pay for euerie such particular default and for euerie such particular day or time soe neglected or omitted, the 
Poena ij. s. somm of ij. s. to bee taken and leauied out of the offendors goods by the constables aforesaid by way of distress and to bee imployed by them as formerlie is appoynted.

None to throwe downe anie

16. Item, wee doe order and appoynt that if anie person or banck made. downe, waste or destroye anie Hill or Banck now made or which shalbee heerafter at anie time made for the preservation of anie of the commons aforesaid except it bee by the appoyntment of the constables and churchewardens of Stretham aforesayd for the time beeing then euerie such offendor shall forfeit and pay for euerie Poena 1oli. such particular........ the summ of tenn pounds of good and lawfull monie of England; Or if anie person or persons shall sett his nett or netts in anie such breache, gapp, or gull, shalbee adjudged and reputed his fact and therevppon shall forfeit and pay the summ of 40 s. of like monie of England.

Noe cattle to bee put into the feilds till 6 days after bee done.

haruest

ended.

Owners of gees to pay iiij. $d$. a foot marke for gees goeing on horse or cowpasture.

18. Item, wee agree that the owner of euerie marke or flock of geese of one foot-marke shall pay vnto the fennreeues the somm of fower pence for euerie default, goeing vppon the horsepasture or cowpasture.

[Here follows a list of 26 names of those who signed these orders.] 


\section{CERTAYNE ORDERS AND BYLAWES}

MADE BY THE CONSENT OF THE

MOST PART AND THE GREATEST NUMBER

OF THE INHABYTANTS OF STRETHAM, BOTH

COPPIEHOWLLDERS AND FREEHOULLDERS AND

OTHER COMMUNERS THERE ACCORDING TO

THE DECREE AND ORDER VNTO THEM

PRESCRIBED \& SETT DOWNE OUT OF

THE HONOURABLE CORT OF HIS

MAJESTIES EXCHECKURE AS

FOLLOWETH THE FOWRE

AND TWENTY DAYE OF

FEBRUARY 1622.

1. Imprimis it is ordered and agreed by the consent of the To common greater part of the Inhabytants aforesayd that it shall not bee for one onelawfull for any freehowlder or coppyhowlder or inhabytant ing house Inhabyting or occupying any ancient communable messadge or and that to tennent to haue euse or inioye the feed common of any more on. communable howses then one, vpon which one he and his famylie shall for the most part bee coutching and abyding, vppon the payne to forfeit and pay for euerye such beast, cow, or calfe, horsse or mare soe kept contrarye to this order and bylaw in lue of anye suche double common for euerye particular default, the summ of Poena ios. tenn shillings of good English monie.

2. It is ordered and agreed by consent of the greatest part as aforesayd that it shall not bee lawfull for anie commoner aforesaid to ioyne with anie other to make vp or keep anye part of the stint of milche kine, workeing horses, or workeing mares except None to joyne with other to make vp full stock vnless the sayd Cottage or tenement have heertofore or shall heerafter descend to anye coheyres, vppon payne to forfeit and pay for euerye such particular default the summ of tenn shillings. 
Prouided allwayes that if, notwithstandeing this order and bylaw, two seuerall persons shall and will keep cattle vppon the cowpasture or horsepasture aforesayde whose goods shalbee seuerallie distinguished and knowne to either of them for that one commonable house onelye wherein the sayd two parties shall cohabit and dwell, that then it shall and may bee lawfull to and for the ouerseers of these orders, or their lawfull deputies, to impound the Cattel of all and euerye such double Commoner soe offendeing and to take for euerie beast soe kept contrarie to this order and bylaw for euerye particular default of euerye offender or offenders whose Poena ros. goods shalbee soe impounded as aforesayd, the summ of $\mathbf{x}$. s. of good and lawfull English monie.

Cowpasture. 3. Item, it is ordered and agreed vpon by the consent of greatest 6 cowes 2 weanelings. part of the Inhabitants aforesaid that it shall and may bee lawfull to and for all and euerie the freehoulders, coppiholders, and Commoners inhabiteing and dwelling within the towne of Stretham aforesaid to keep (accordeinglie as is formerlie set downe) or depasture within the heardwalke of Stretham six milche kine and two weaneling calues onelie and noe more : Prouided alwaies that if anie commoner aforesaid shall and will keep and depasture vppon the said heardwalke a sufficient bull which shalbee valued 7 cow's with at the summ of fortie shillings at the least, then euerie such coma bull. moner soe keepeing such a sufficient Bull as is aforesaid shall keep one cow the more aboue the number of six formerlie proescribed And what commoner soeuer aforesaid shall exceed anie of these rates respectiuelie formerlie sett downe for euerie particular beast Poena Ios. soe kept contrarie to this Order and bylaw, shall forfeit and pay the summ of tenn shillings of good English monie.

Horsepas- $\quad 4$. Item, it is likewise ordered and agreed that it shall and may ture. 8 workeing

horses

mares with their foales vnde
9 moneths 9 mone. bee lawfull for euerie commoner as is aforesaid to keep and depasture within the horsepasture in Stretham aforesaid called Stallock Hay Fenn, and the green, the number of 8 workeing Horses or workeing mares with their sucking foales soe as the said sucking foales bee vnder the age of nine monethes olde and noe greater number and of noe greater Age vppon payne to forfeit 
and pay for euerie such particular horse or mare aboue the number of 8 as is aforesaid and for euerie such particular foale aboue the Poena ros. Age aforesaid the summ of tenn shillings of good English monie.

5. Item, it is ordered and agreed by consent as aforesaid that it Lawfull to shall and may bee lawfull to and for euerie Commoner as aforesaid hire cattle not haueing his or their number or stint of milche kyne or Commons. workeing horses or workeing mares, to make vp the said number by hireing the same soe that euerie such commoner soe hireing as Prouiso. is aforesaid shall hier, haue and keep the same milche kine and workeing horses and workeing mares respectiuelie without fraud or guile for the space or terme of 6 monethes at the least and soe to bee kept 6 moneths. shall keep them, vppon payne to forfeit and pay for emerie such particular cow, horse or mare soe had or hired and not kept to the full number of the time of six monethes as is aforesaid, the summ Poena Ios. of tenn shillings of good English monie.

6. Item, it is ordered and agreed that it shall not bee lawful for anie commoner aforesaid to keep and depasture anie weaneling A prouiso or exception to the third calfe vppon the cowpasture aforesaid which hath been or shalbee calued beefore the feast of St. Michael yeerlie, to bee kept the summer followeing vppon the heardpasture aforesaid in the name of a weaneling calfe vppon payne to forfeit and pay for euerie suche particular calfe, soe kept contrarie to this Order and bylaw Poena 5 s. the summ of fiue shillings of good English monie.

7. Item, it is ordered and agreed that it shall not bee lawfull for anie commoner aforesaid to leep and depasture vppon the horsepasture anie horse or mare vnder the age of two yeeres olde except the same horse or mare bee a common and vsual workeing beast or shalbee adjudged to bee fitt soe to bee for stature by the ouerseers of theise bylawes, vppon paine to forfeit and pay for euerie suche particular horse or mare soe kept contrarie to this Poena ros. order and bylaw the summ of $\mathrm{x}$. s. of good english monie.

8. Item, it is ordered and agreed by the consent of the greater part of commoners aforesayd that it shall not bee lawfull for anie residents. person or persons whatsoeuer to keep or depasture within anie part or parcell of the sixteen hundred acres prescribed and sett

A prouiso or exception to the fourth Article. Article for weanelings. 
downe by the honourable court of his Majesties exchequer to the commoners and inhabitants of Stretham and Thetford onelie anie milche kyne, weanling calues, workeing horses or workeing mares, or anie other cattle of what qualitie or sorte soeuer the same bee or heerafter shalbee for anie commonable messuage or tenement within the bounds and lymitts of Stretham aforesayd, except euerye person aforesayd, or at least the wife, children, or familie of euery such person or persons so commoning as aforesayd, shall continuallie bee resideing, abydeing, inhabiteing and dwelling in and vppon euerie such commonable messuadge or tenement vppon payne to forfeit and pay for euerie such particular default and for

Poena ros. euerie such particular beast soe kept contrarie to this order and bylaw the summ of $\mathrm{x}$. $s$. of good english monie.

Joysteing forbidden.

Poena $40 s$.

A second prouiso against the $5^{\text {th }}$ article.

Poena 4 os.

Agaynst infectious cattle.
9. Item it is ordered and agreed by the conseut of the greater part as aforesaid that it shall not bee lawfull for anie commoner whatsoeuer to colour or take to joyste anie beast whatsoeuer vppon payne to forfeit for euerie such particular beaste soe coloured and taken to joyst as is aforesayd the some of 40 s. of good English monie. Prouided allwayes that if anie person or persons whatsoeuer beeing formerlie tolerated and allowed to hier his stynt of milche kyne and workeing horses for the space of six moneths as is aforesaid and shall not haue, vse, occupie, and enjoy all and euerie such beaste and beastes soe had, hyred, and obtayned by the whole terme and tyme of six moneths aforesayd, then euerie such beast, soe had hyred and beeing not kept by the space of six moneths aforesayd, shalbee adjudged to bee a coloured beast, and then euerie person who did keep such beast shall pay as is aforesayd the summ of 40 s. of good english monie.

10. Item, it is ordered and agreed by the consent of the greater part as aforesayd that it shall not bee lawfull for anie commoner, or commoners whatsoeuer to depasture and put to feed within the bounds and lymits of the cowpasture or horsepasture of Stretham aforesayd anie Horse, Mare, cow, or other beaste whatsoeuer which shall anie way bee infectious but shall within one daies warning given by the ouerseers of these bylawes or the fenreeues for the 
time beeing remoue and put away euerie such infectious beast, vppon payne to forfeit and pay for euerie such infectious beast soe kept and not remoued from off the commons aforesayd the summ Poena Ios. of tenn shillings of lawfull English monie.

11. It is ordered and agreed by consent as is aforesayd that it Fodder to shall not bee lawfull for anie person or persons whatsoeuer to cutt, bee but once crop, or mow anie edich ${ }^{1}$ or edgrowth, in anie common fenns of eache yeer. Stretham aforesayd at anie tyme in the yeer after it is or shalbee once mowen for that yeer, vppon payne to forfeit and pay for euerie such howres worke, and soe after the rate of a greater or lesser Poena $5^{s}$. proportion of time the some of fiue shillings of good English monie.

12. It is ordered and agreed by the consent of the greater part as aforesayd that it shall not bee lawfull for anie person or persons whatsoeuer to brink cart, or carrie anie Hay, stouer, or fodder out of anie of those grounds called Feedall fenn, charfen Hills, or Noe fodder to bee carted or carried for strangers. willow fen into or thorough anie of those our commons called Howle fenn and charr fenn playne, or into anie partes or members of the sayd fenns for anie stranger or strangers whatsoeuer, not beeing a commoner in Stretham aforesaid, vppon payne to forfeit and pay for euerie such loade or carriage soe carted or carried Poena 5 s. as is aforesayd the summ of fiue shillings of good english monie.

13. Item, it is ordered and agreed by the consent of the greater Noe fireing part as is aforesayd that it shall not bee lawfull for anie person or persons whatsoeuer or anie their assignes to cutt or digg anie Hassocks, fireing or turberie within anie part of anie of the common fenns of Stretham aforesayd called Lazer, charfenn playne and Howle fenn, vppon payne to forfeit and pay for euerie such howres worke and soe after the rate of a greater or lesser propor- Poena 5 s. tion of time the summ of v. s. of good English monie.

14. Item, it is ordered and agreed by the consent of the greater part as aforesaid that euerie person or person whatsoeuer haueing anie part or partes in the partition ditch called Barlake, which is beetween the [cow-]pasture and horsepasture of Stretham aforeto bee cutt and taken out of the common fenns.

1 This term applies strictly to the growth on the stubble, (or haulm), field, but is here used of aftermath generally. 
said, shall yeerlie and euerie yeer from time to time and at all times needfull and convenient ditche, scowre, clense and sufficientlie keep his or their such part or partes in the said partition ditch called Barlake after two daies warning given to him or them by the ouerseers of these orders, or anie one of the fenn reeues for the time beeing, vppon payne to forfeit and pay for euerie suche faultie part or partes not sufficientlie kept and scoured as is aforePoena 3s. said the summ of three shillings fouer pence of good English [sic.]

Prouiso. monie.

Prouided allwayes, that if after such warning giuen as aforesaid anie part or partes shall continue and remayne vndone or not sufficientlie scoured as is aforesaid, then wee order and agree that it shall and may bee lawfull to and for the ouerseers of these orders or anie one of them to procure, hyer and gett anie man whatsoeuer to scowre, ditch, and amend the same and to pay the same labourer or labourers for such their worke and workes out of the aforesaid forfeited summ or somes of iij. s. iiij. $d$. as is aforesaid.

Debarring of 15. Item, it is ordered and agreed by consent of the greater part horse from cowpasture : cows from horsepasture. as aforesaid that it shall not bee lawfull for anie commoner or commoners or anie other person or persons whatsoeuer to depasture and put to feed within anie the bounds and lymits of the cowpasture aforesaid anie workeing horses, workeing mares, or suckling foales or to depasture and put to feed within anie the boundes and lymits of the horsepasture aforesaid anie milche kine or weaneling calues, except the same shalbee soe agreed vppon by consent of the greater part of the commoners and inhabitants of Stretham aforesaid, vppon payne to forfeit and pay for euerie such particular beast respectiuelie soe kept and depastured contrarie to Poena 5s. this order and buylaw the summ of fiue shillings of good english monie.

Agaynst 16. Item, it is ordered and agreed by the consent of the greater By-heards. part as aforesaid that it shall not bee lawfull for anie commoner or commoners whatsoeuer, or other person whatsoeuer, to despasture and put to feed within anie the bounds and lymits of the cow- 
pasture of Stretham aforesaid anie by-heard, or heards, bee the number thereof great or small, but shall suffer and permitt the common heardman of Stretham aforesaid to driue and bring home euerie such beast and beasts among his whole heard without interruption or contradiction, vppon payne to forfeit and pay for euerie such particular beast and for euerie particular time soe kept contrarie to this order and bylaw the summ of iij. s. iiij. $d$. of good Poena $3 s .4 d$ English monie.

17. Item, it is ordered and agreed by the consent of the greater part as is aforesaid that it shall not bee lawfull for anie commoner or commoners, or anie other person or persons whatsoeuer, to put back and leaue beehinde anie milche cowe after the whole Heard Agaynst leaueing of cowes all night in the for the moste part is come home to the end to depasture and feed the same within anie the bounds and lymits of the cowpasture of Stretham aforesaid, except the same milche cow shalbee soe lame Prouiso. that it cannot well come home or shall haue newlie calued, and soe for the first night onelie, vppon payne to forfeit and pay for euerie such particular beast and for euerie time soe kept back or left beehinde wilfullie contrarie to this order and bylaw the sum of iij. s. Poena $3 s .4 d$. iiij. $d$. of good English monie.

18. It is ordered and agreed by the consent of the greater part Agaynst as aforesaid that it shall not bee lawfull for anie commoner or commoners or other person or persons whatsoeuer to cutt, digg, delue, or thrust thorough or make anie breache, gapp, or gull, in anie gaps or gulls in anie part of anie banke or fence made by consent for the keeping of anie the commons aforesaid from inundations and ouerfloweings of the waters, except the same shalbee thought fitt and appointed to bee done by the constables of Stretham for the time beeing, together with the consent of the ouerseers of these orders and bylaws for the time beeing, vppon payne to forfeit and pay for euerie such particular default and for euerie suche particular breache or gull for euerie particular time the same shalbee done contrarie to this order and bylaw the summ of 10 s. of good english Poena ros. monie.

Prouided allwayes, that if anie person or persons soe offendeing Prouiso. 
Noe net to bee set in anie breache.

Poena 40.

Prouiso.

shall not haue goods and chattells sufficient goeing vppon anie the commons aforesaid which shall and wilbee able to answer the penaltie aforesaid, it shall and may bee lawfull to and for the ouerseers of theise orders and bylawes, or anie one of them for the time beeing, to take and seize into his or their hands and custodies as dammage phesant all and euerie the nett and netts of euerie person or persons soe offendeing as is aforesaid.

19. Item, it is ordered and agreed by consent of the greater part as aforesaid that it shall not bee lawfull for anie commoner or commoners or anie other person or persons whatsoeuer to sett, or sett downe anie manner of nett or engine whatsoeuer in anie breache, gapp, or gull, beeing made contrarie to the order aforesaid at the riseing and ouerfloweing of the waters vppon payne to forfeit and pay for euerie such particular nett or engine soe sett or caused to bee sett in anie such particular gapp, or gull the summ of 40 s. of good English monie.

Prouided allwayes, that if anie person or persons whatsoeuer shall put or sett downe anie manner of nett or engyne whatsoeuer in anie breache, gapp or gull beeing made contrarie to the order before-mentioned at the ebbing and falling of the water then euerie such person or persons haueing formerlie sett his or their netts as aforesaid shall within 3 dayes next after the water is for that season at the lowest amend and embank the same breache, Poena Ios. and breaches, agayne vppon payne to forfeit for euerie such particular default the summ of 10s. of good English monie.

... dispose of

20. Item, it is ordered and agreed by consent of the greater part the $\ldots . .$. of charfen hills as aforesaid that it shall and may bee lawfull to and for the ouerseers of these orders and bylawes yeerlie and euerie yeer from time to time, and at all times heerafter, to alien, sell, and dispose of all and euerie the proffitts and commodities of ........ all the fodder and stouer which now is or which heerafter shall ......... and arise in anie the towne parts of the fenns called char fenn hills, and willow fenn att their best likeings and discretions, And the monie thereof comming or soe much thereof as shalbee requisite to bee by them or anie of them disbursed and layed out 
for the answering of anie sute or sutes, action or actions brought or commenced agaynst them or anie of them toucheing and concerning the keeping or breakeing anie of these said orders and bylawes.

Prouided allwaies, that if it shall happen that noe suite or suites, action or actions shalbee commenced or brought agaynst anie of them beefore the Feast of St. Andrew yeerlie, then the ouerseers of these orders haueing receiued monie for the aforesaid fodder grounds shall then yeeld vpp and giue a true and sufficient account of all such monies soe receiued and not by them imployed and layd out accordeing to the discretion of the said ouerseers in anie Prouiso. part of the 16 hundred acres aforesaid.

21. Item, it is ordered and agreed by consent of the greater part as aforesaid that if anie inhabitant within our towne of Stretham aforesaid, or anie other person or persons whatsoeuer lyable to these or to anie one of these our orders and bylawes, shall willinglie and wilfullie violate and breake them or anie one of them whereby the ouerseers of these orders and bylawes shalbee stirred and moued either to take as distress for the satisfying of anie penaltie heerin conteyned, or to commence anie sute or sutes, or defend anie action or actions toucheing the keeping and obserueing of all or anie these our orders and buylawes, that then it shall and may bee lawfull to and for the sayd ouerseers or anie two of them for the time beeing, from tyme to tyme and at all times needfull, not haueing formerlie receiued sufficient monie and not by them layd out, to make, leauie, and collect such reasonable rate and rates, summ and summes of monie by taxeing and assessing euerie such workeing beast and euerie such milche cow which then shall depasture and feed within the bounds and lymitts of Stretham aforesaid or which shall haue fedd in anie part of the summer beefore the said sute or suites shalbee commenced as aforesaid; which rate or taxation if anie inhabitant or anie other whatsoeuer lyable to these or anie of these our orders and bylawes shall refuse and neglect to pay his or their part or partes from time to time and at all times soe assessed, then euerie such partie and parties 
soe neglecteing to pay the same by the space of sixe daies next after request made by the ouerseers of the sayd orders or anie one of them shall forfeit and pay for euerie such neglect and default Poena Ios. ouer and aboue his taxation the summ of 10 s. of good english monie.

Ouerseers power in necessarie publique works.
Fenreeues the ouerseers assistants.

22. Item, it is ordered and agreed by the consent of the greater part as aforesaid that it shall and may bee lawfull to and for the ouerseers of the sayd orders or anie two of them, from tyme to tyme and att all times heerafter dureing the time of their sayd office, to haue perceaue and take all and euerie such penall summs of monie, penalties and forfeitures as are heerin expressed and sett downe, and for default of payment thereof to implead, impownd, driue or distreyne euerie partie or parties or the goods and chattells of euerie partie and parties soe offendeing. And out of such monie or monies soe or anie other way receiued, to make, builde and erect such sluces, draynes, water courses and waterings on anie of the aforesayd proemises as they or anie two of them shall think meet and convenient for the drayneing and letting out or for the letting in or keeping in or keeping out of anie waters in anie place or places in and about anie of the cowpasture or horsepasture of Stretham aforesaid.

23. Item, it is ordered and agreed by consent of the greater part aforesaid that it shall and may bee lawfull to and for the fennreeues for the time beeing to bee alwayes assistant and coadjutors to the sayd ouerseers, and at the appoyntment of the ouerseers aforesaid and not otherwise, and in default there bee noe ouerseers; the fennreeues from time to tyme to driue and impound all or anie the goods and chattells of euerie person or persons offendeing and breakeing these or anie of these our orders and bylawes which are or ought to bee obserued, performed, fulfilled and kept.

The time of laying out the fenns.

24. Item, it is ordered and agreed by the consent of the greater part as aforesayd that all and euerie the orders and bylawes which shall at anie time euer heerafter bee made toucheing the stinteing, ordering, or directing of the 16 hundred acres of common allotted to the towne of Stretham and Thetford respectiuelie shall for 
euermore heerafter yeerlie and euerie yeer bee made vppon shrouemunday or shrouetuesday in euerie yeer, and at noe other time in anie yeer.

Prouided allwayes, that if it shall happen that at the aforesaid Prouiso. dayes and times the greater part of the inhabitants shall refuse or neglect to meet toucheing the makeing and setting downe of such orders and bylawes as they shall think necessarie, then wee order and appoynt that all and euerie the orders and bylawes lastlie and formerlie made and agreed vpon by the consent of the greater part of the commoners and inhabitants of Stretham aforesayd shall continue in full force and vertue. And wee doe further order and agree, by consent as aforesaid, that all and euerie these our orders and bylawes shall remayne and continue in force vntill the daies formerlie sett downe and soe forward from time to time and att all times heerafter vntill the same or anie one of them bee reuersed, altered, renued or continued at the saicl appoynted dayes, and not otherwise, by consent of the greatest part of the inhabitants of Stretham aforesaid.

25. Item, wee doe appoint Francis Frances, Michael Fludd clarke, John Bentlie to bee and remayne ouerseers for these and euerie one of these our orders and bylawes to see that the same bee fullie perfourmed, fullfilled and kept; And wee doe order and appoynt that they and euerie of them shall continue in their sayd office vntill shrouetide next and noe longer, except the greater part of the inhabitants together, with their owne consents, shall think fitt and convenient to continue them or anie one of them in their said office anie longer time.

26. Item, it is ordered and agreed by the consent of the greater part aforesaid that it shall not bee lawfull for anie person or persons whatsoeuer to keep or put to feed anie manner of swyne hoggs vppon anie part of the cowpasture or horsepasture or anie part of the green parcell of the horsepasture aforesaid vntill the harvest of Stretham bee fullie ended, vppon payne to forfeitt and pay for euerie such particular swyne as aforesaid, and for euerie particular default the summ of two pence of good English monie. Poena $2 d$. 
Prouiso. Prouided allwayes, that notwithstandeing this last order aforesaid it shall and may bee lawfull to and for euerie commoner aforesaid to putt his hoggs and swyne aforesaid at all tymes in the green onelie, beeing lawfullie ringed, soe as none of the aforesaid hoggs beeing soe putt vppon the green as aforesaid shall depasture and feed vppon anie the commons aforesaid, except beefore excepted, vnder the payne and penaltie of the summ of ij. $d$. of good english monie for euerie particular default.

Hee that

keeps noe weaneling calfe may keep one cow more than his stint.

27. Item, wee order and appoynt that what soeuer commoner aforesaid shall forbeare to depasture and feed anie weaneling calues within the heardpasture or horsepasture aforesayd shall for the time of such forbearance depasture and keep within the common one cow the more.

Undersetters to keep one cow onlye vppon the but not without leaue.

Ouerseers of these bylawes.

Neglect of the ouer-

28. Item, wee doe order and appoynt that it shall not bee lawfull for anie inhabitant inhabiteing and dwelling in anie new erected cottage, beeing no auncient commonable house, to depasture and put to feed within anie commons aforesaid more then one milche cow, and whosoeuer shalbee permitted to keep anie such cow shall not presume soe to doe except hee or shee shall first haue leaue giuen him or hir in open churche vppon some Sabboth day after euening prayer by the greater part of the commoners there then present.

29. Item, wee doe nominate and appoynt Richard Langford, Thomas Cheuill, Wm. Townson, Richard Bent, John Bent, Edward Hayward and Robert Flintoft to bee and remayne ouerseers for theise orders and bylawes; and wee doe heerby giue to them or anie two of them free libertie and authoritie to receiue and take all such penalties and forfeitures as are heerin agreed vppon for the breache of them or anie of them; and further wee order that if the aforesaid ouerseers shall neglect or refuse to impound anie cattle, geese, hoggs or sheep which shall depasture or feed vppon anie the seers to bee commons aforesaid, that then it shalbee and may bee lawfull to supplied by and for anie the auncient commoners aforesaid to driue and inhabitant. impound anie beast or cattle soe kept contrarie to these orders and 
bylawes and the penaltie or penalties for the breache thereof to receiue and take to the vse of him or them who shall soe impound for their labour and paynes therein.

In witness whereof wee haue heerto sett our seuerall hands and marks. Dated the day and yeer first abouewritten.

[Here follows a list of 48 names of those who signed these orders.] 


\section{A COPPIE OF AN ARTICLE}

FOR A LIBELL FOR THE TITHE OF HERBAGE OF STEERS, DRIE COWS AND HEIFERS, AND HORSES AND MARES NOT KEPT FOR TILLAGE; DRAWN BY R. C.

That W.B. had in the moneth libellate within the parish libellate \&c. viz. in a peece or parcell of marish ground beeing seuerall, conteineing ${ }^{1}$ acres called ${ }^{1}$, the said W.B. had kept, fed and fatted fortie steers, drie heifers, \&c. which were not bred nor weaned within the parish libellate, nor euer vsed, imploied or maineteined for the plough or the payle within the parish libellate, whereof or of the fall of them neuer anie proffit came to the churche to the parish (sic), but they were brought in by the said W.B. when they were leane to bee fed and fatted for the butcher, and were there kept, fed and depastured in the yeers libellate vntill they were fatted and then solde them to diuers butchers and others for farr greater summs of monie than was paid for them when they were leane; and by such feeding and fatting of those steers and heifers within the parish aforesaid the said W.B. gained in euerie steer xl. s. and euerie heifer 40s. the herbage, pasturage and feeding of euerie such beast beeing worth iij. $s$. iiij. $d$. euerie week and the tithe thereof due accordeinglie \&c.

1 Left blank in the MS. 


\section{A COPPIE OF AN ARTICLE}

\section{FOR A LIBELL FOR TYTHE MILKE EODEM AUTORE}

That in the yeer libellate E.H. did not sett forth, deuide, sett forth and pay the tenth part of milke. ${ }^{1}$

First that the auncient custome of the parish is and hath been to pay the whole milke of all their kine within the parish euerie nyneth night and tenth morning between \&c. euen as the same is milked and taken from the cowe or cowes, without anie diminution or alteration of anie part thereof, and without anie fraud or deceipt therein whatsoeuer.

That E.H. in the yeer attestate did not sett forth, deuide and pay the whole milke of all his cowes euerie 9th night and 10th morneing accordeing to the custome, but did keep back a part of the best of that milke and added water and other vnwholesome things to that milke hee had sett forth, thereby to deceiue the parson \&c.

That if anie time hee did deuide and sett forth the tithe milke trulie and justlie accordeing to the custome, yet E.H. did after the same was soe sett forth take back the same soe sett forth and did employe the same to his owne vse or otherwise soe dispose thereof as it beecame of noe vse or value to the parson.

That if \&c. quod non fatetur \&c. yet the same was soe sett forth at such unreasonable times and at such places, distant a mile or 2 from the parsonage, and immediatelie taken away agayne beefore the parson could come to receive it, of purpose to let slip or hinder the parson thereof and of purpose to defraud and deceiue the parson.

1 This paragraph has been cancelled in the MS. 
, 


\section{INDEX}

Adjistment, (joistment), I78, I78n, $203,278$.

Adventurers' Land, 237n.

Alborough, (Alborowe,) 199, 202, 203, 2I 5, 2 I9.

Alcock, Thomas, 209, 2 I3.

Aldrith, Calsey, I79.

Annys, Henry, 197, 199.

Arable Land, 257, 260, 269.

Articles of Agreement, I86, 222, 223, 224, 225-229.

Atkins, Richard, of Cutwell, 179.

Bailiffs, 2 I I, 2 I 2, 255, 256.

Banks, Robert, 225, 227.

- , 179, 180, 183, 205, 206, 207, 208, 2 I0, 23I , 232, 240, 273. 274.

Barkers Coate, $27 \mathrm{I}$.

Barker, Francis, 265.

Barlake, 259, 266, 279, 280.

Barley, 258.

Barnes, Mr., I87.

Barnwell Abbey, 175.

Barreditch, 233.

Bars, see rails.

Batisford, John, I 84 .

Baulks, 237.

Beans, cultivation of, 270.

Becks, The, 2 I9.

Bedford, dukes of, 176 .

Bell, warning given by, 240 .

Bellman, The, 230.
Bent, John, 286.

- , Richard, 286.

Bentlie, John, 285.

Blean, Edward, 225.

Branding, of Cattle, 232, 233.

Breaches, see Gullies.

Bridges, I 79, 2 I9.

Brigham, John, 225, 227.

Broad Land, 200.

Brown, Francis, 198.

Bull, John, 225.

Bulls, 236, 276.

Bullock's Harst, 2 I 5, 2 I 9.

Bull Piece, the, 208.

Burdlaries (alias Harlstone) Manor of, 197, 198, 201, 207, 209.

Burlings, $216,220$.

Burwell, Thomas, 248.

Bye-Herds, 220, 235, 280, 28 I.

Bye-Laws, see Orders,

Bynge, Henry, 184 .

Cambridge, I75.

- , Christs' College, I78, I94, I98, 200, 201, 203, 209.

— , King's College, r95, 228.

- , St. John's College, I 95, 200, I 78, I 89.

- Way, 197, 199.

Carts, 239, 240.

Cass, Mrs., I 8I.

Casting, $27 \mathrm{I}$. 
Cattle, I 73, I83, I85, $211,213,214$, $215,216,217,218,219,220,232$, $233,234,235,236,237,238,240$, $242,243,244,246,247-250,274$, $276,277,278,280-282,286$.

- , disease amongst, 238 .

- , droves and drifts of, 224, 243.

Charfen Hills, 279.

Charlode, 205, 206.

Chesterton, 175.

Chevill, Thomas.

Childerley, I 75.

Chimneys, 265.

Chittering Hill, 21 5, $217,230,235$, 238.

Christening, 252.

Christs' College, see Cambridge.

Churching, $25^{2}$.

Close, Alborough, 234.

- , Curds Willows, 200.

- , Eastland, 197.

- , the Holme, 236.

- , Horsemore, 197.

— , King's Cross, 196, 197, 199, 220.

- , Little, in Cottenham, ig6.

- , Long Hill, in Cottenham, I96, 227.

- , Marehill and Tillage, 196,198.

- , Pelham's Croft, 200.

- , Kits' Bush, 197, 198, 202.

Clarke, John, I87.

Clay Lakes End, 265.

Clay pits, 216, 238, 239.

Coateman, John, 272.

Coke, Edward, 178 .

Coloring, of Cattle, 219, 237, 237n, 278.

Commoning house, 275.

Common Land, I73, I74, I74n, I 79, I 98, 202, 204, 207, 209, 2 I I, $2 I_{3}, 214,215,219,220,223,228$, 230, 232, 237, 238, 241 .

- , (in Stretham), 260, 277.

Constables, 266, 27I, 272, 273, 274.
Copyhold Tenants, 253, 254, 255, $256,275,276$.

Cottage, 204.

Cottenham, 194, 196, 197, 200, 202, 203, 204, 205, 206, 207, 208, 210 , $2 \mathrm{II}, 2 \mathrm{I} 2,2 \mathrm{I} 3,2 \mathrm{I} 4,2 \mathrm{I} 5,218$, and passim.

- , chapel in, 209, 2 II.

- , Church of, 208, 2 I I , 2 I 6, 225.

- Common in, 198, 209, 213 , $214,215,219,224$.

- , Manor of, I97, I99, 201, 208, 209, 2 I 3.

- , parson of, 209, 214.

- , Rectory of, I 80, 195, 197, 198, I 99, 2 I I.

- , School in, 209, 244.

Cotton, Sir John, I 85 .

Courts, of the lord of the Manor, 2 I 2.

Cow Pasture, the 2 I 8, 230, 232, 234, $235,236,271,273,274,276,277$, $278,279,280,28 \mathrm{I}, 284$.

Cowaies end, 238.

Cow-way, $218,243$.

Cox, Sir Richard, 261, 263.

Creeks : the Abbots' Creek, 208.

Cresses, 232.

Crofts, 241 .

Crowlands, Manor of, 177, I94, 196, I 97, 203, 205, 207, 209, $214,208$.

Crykle Fen Bank, 21 5, 2 I6, 220.

Curde, William, 204.

Dairy farming, 173 .

Damage phesant, 282.

Dellfen, 2 I 5, 2 I9.

Ditches, 205, 206, 207, 210, 234, $236,237,240,24$ I , 242, 265, 279, 280.

Drainage, I76, I 82, 1 82n. 204, 241 .

Drains, I98, 2 I9, 265, 27 I, 272, 284.

Drifts, of Cattle, 224, 234 .

Droveyard, 224.

Edgrowth, 279, 279n.

Eden, Dr., vicar general of the Bishop of Ely, $246,249$. 
Egg, rent, 185 .

Egnie, Thomas, 265.

Elford, 258, 265 .

Ely, Bishop of, I77, 185 .

- , Bishop of, see Felton.

- , Cathedral of, I95.

- , Dean and Chapter of, 178 , 200, 209.

Isle of, the, $175,263,265$.

England, King of, James I, 267.

Epworth, i76n.

Farmers of the Manors, 208, 209.

Felton, Nicholas, Bishop of Ely, I 9 I.

Felton, Nicholas, Rector of Stretham, I9I.

Fences, 205.

Fen, keepers of the, 204, 216, 217, 2 I 8.

Fens, 179, 196, 204, 279, 284.

Michaelleye, (Michelleye, Michaeley) I79, 216, 219, 232, $234,235,236,242$.

- , Topham, I79, I8o.

- , Denney, I79.

- , Hole Fen Lazer, 259.

- , Stallock Hay fen, 276.

- , Feedall Fen, 279 .

- , Willow Fen, 279, 282.

- Awbrose, 179, 180.

— , Sechall, r 79, 234, 236.

- Sechall Chairefen, I79.

- , Chittering, I79, I80.

- Common, 179.

- , Cuttes, I80.

- , Willow, 180.

- , Thetford Hall Fen, 256, $25^{8}$.

- , Grunty Fen, 256.

- , Hole Fen, 258, 279.

- , Charr Fen Plain, 279.

- , Lazar Fen, 279.

- Smithey, I79, 205, 207, 208, 219, 234, 235, 242, 25 I.

- Chare, I79, 180, 259, 282.

- , Hay Fen, 259, 26I, $27 \mathrm{I}$.

- , North Fen, 205.
Fens, North Fen, Great, 220.

- , - - Little, 202, 220.

- , Young Man's Fen, 208.

- , Crikle, 198.

- Stretham, 184.

Fen Reeves, I 82, I85, 240, 242, 268, $274,284$.

Ferriage, privilege of, $25^{8}$.

Ferry house, the, 258.

Fields, I96, 202, 257, 268, 269, 274.

- , Church Field, 199.

- , the Common Field, 200.

- , Dunstall, 197, I98, 200, 202, 219, 234 .

- , The Fallow Field, 235, 24I.

- , Farm Field, 200.

Fields, Ferne-Field.

- , Foxall, 197, 200.

Field, the Halme Field, 235.

Field Reeves, 220, 221, 236, 24I, 242,245 .

Fines, 205, 206, 207, 210, 21 I, 212, 213, 216, 217, 218, 219, 220, 221, 222 , and $230-252,256$.

Fireing, 279.

Fishing, 206, 208, 209, 232.

Flintoft, Robert, 286.

Floods, 233.

Flood, Michael, of Stretham, 26o, 285.

Foals, 250.

Foot-mark, 274.

Forrends, 237.

Fowls, 251.

Fowl, liberty granted to, 205 .

Frances, Francis. 285.

Frankham, Thomas, 260.

French, Mr., rector.

French, Robina, 18r.

Fruit, 246, 247, 248.

Furrowes, 237.

Gates, 179, 231, 233, 236, 243.

- , double falling, $242,242 \mathrm{n}$.

Geast cattle, the, 23I, 234, 235 .

Geese, 25 I, 274. 
Geldings, 220.

Gleaning, 267, 268, 269, 270.

Goldsmore, common in, 263.

Govern, to, 257.

Gravel pit, 238.

Green, Anthony, I98.

- , the, 280, 286.

Gullies, 232, 282.

Haddenham, I76, 177.

Haffing, 27I, 272, 273.

Halfhead, Thomas, I97.

Harlstone, see Burdlaries.

Harvest, 23I, 235, 260, 262, 267 , $268,274,285$.

Hassocks, 279.

Hawards, 242, 243.

Hawk, liberty granted to, 205 .

Hay, 246, 247, 248, 25 I, 279.

Hayhow, W., 187.

Hayward, Edward, 286.

Heardman, the common, $28 \mathrm{I}$.

Hedges, 23 I.

Heifers, 288.

Hemp, 25 I.

Hempland, 200.

Herdman, Town, 220, 237.

Herd-pasture, the, $277,286$.

Herd-walk, the, 276.

Heriots, I84, I85, 255.

Hildersham, I75.

Hinde, Sir Francis, I77, I78, 201, 207, $214,222,223$.

Hinde, William, of Maddingley, I 78, 179, 180, 187, 188, 194, I96. I97, 20I, 202, 203, 204, 205, 206, 208, 21 2, 214, $218.219,221,222$, $223,224,225,226,227$.

Histon, 197, 198.

- , Moor, 199.

Hobson, Thomas, 180.

- , Katherine, 180.

Holbeam, Thomas, 228.

- , William, 228.

Holm, 202, 208, 234, 236.

Holme-Bridge, the, 204.
Holmes' Corner, the, 204.

Holme Meadow, 236.

Honey, 251.

Horsepasture, 271, 273, 274, 276, $277,278,279,280,284,285,286$.

Horses, 220, 233, 238, 259, 260, $26 \mathrm{I}, 26 \mathrm{In}, 262,263,275,276$, $277,278,288$.

Houses, 180, 204, 258, 275.

Hovels, 204.

Humfrey, Thomas, 225, 227.

Hunt, liberty granted to, 205.

Hurdles, 23x.

Impounding, $217,218,224$.

Inclosures, I 74, 1 85, 189, 196, 197, I $98,199,201,202,203,214,223$, $227,251,252$.

Inn, the Bull, I76.

Isacson, Christopher, 266.

Ivatt, William, 245.

Jackson, Thomas, 225, 227.

- , Thomas, the younger, 225, 227.

Jades, 233, 234.

James I, see England, king of.

Jenyns, Soames, 182.

Joistment, see Adjistment.

Kings' Cross Way, 196, 2 15, 216.

Lakes, 232, 265.

- , Long Lake, $27 x$.

- , Thoroughout Lake, 272, 273.

Lakes Ende, 242.

Lambs' Cross, I97.

Landbeach, 196.

- , Fen Side, 2 r9.

- , Moor, 199.

Lands-ends, the, 202.

Langford, Robert, 286.

Layer, 23 I, 23 In, 243.

Leavings, the, 208.

Leys, 202, 204.

Loade, 232.

Longhill, 238.

- Denny, 234.

Loosmyre, 239.

Lot Ditch, the, 215, 216, 2 I 7, 220. 
Lots, $215,220,221,235$.

Lovell, Thomas, 244.

Lowfenns, the, 230, 235, 236, 240.

Lyles Farm yard, 224.

- , Manor of, 177, 194, 196, 197, 203, 205, 208, 214.

Lyon, Robert, 204.

Male, Walter, I8o, I 86, 246, 247.

Manby, Dr. Richard, rector, I8I.

Marehill, 2 I 5.

Marriage, $25^{2}$.

Marsh land, in Stretham, 254, 255, 288.

Maw, Leonard, I8r, 248.

- , Dr., rector of Cottenham, 246.

- , Nicholas, 248.

Masters, Rev. Robert, 185 .

Meadow ground, 202, 203, 236.

Measures, of land, 207, 232, 239, 24I, 272, 273.

Milch kine, 203.

Milk, tithe, 289.

Moorecloses, 239.

Mortuaries, 252.

Mowing, 209, 2I5, 238, 264, 267, 279.

Nets, 282.

Newditche, 235.

North, Lord, I78, I80, I86, I88, 228.

Northfenside, 23I, 235.

Nye, Mr., I 82.

Oblations, 246, 247, 248, $25 \mathrm{I}$.

Officers, Town, 204, 206, 2 I 2, 2 I 7 , 2 I $9,220,22$ I, 224, 232, 233, 237, 238, 240, 242, and passim.

Orders, 2 II, 2I 2, 2 I3, 220, 22I, 257.

Order Makers, the, I83, 204, 208, 209, 2 I O, 2 I I, 2 I 2, 2 I 3,2 I 4, 2 I 5 , 2 I 6,2 I 7,2 I $8,220,22$ I , 232, 237 , $238,241,242,244,245$.

Outlaw's Cot, I79.

Oziers, 206, 23 I.
Page, Anthony, 185 .

Pales, 22 I.

Peas, cultivation of, 269, 270.

Pelhams, Manor of, 209.

Penalties, see Fines.

Pepys, George, I78, I87, I88, 223, $225,227$.

- , John, I97, 198, 199, 20 I.

Peterborough, bishop of, 178 .

Phillip, John, 245.

Pigeons, $25 \mathrm{I}$.

Piggott, William, 266.

Ploughing, I84, 215, 2 16, 253.

Plow-Penny, the, $25 \mathrm{I}$.

Pound, the, see Impounding.

Pound Reaps, 253.

Pound wall, the, 266.

Rails, 23I, 233, 243.

Ramsies, John, 265.

Reaping, 267.

Rents, see Securities.

Rents, hen, 185 .

Rivers, Robert, 207.

Rivers, the Cam, 173, 176.

- , the Ouse, I73, I76, I80.

- , the Nene, I76.

Roads, 200, 2 18, 238, 243.

Robbins' Lode, I 79.

Roods, see measures.

Rooking, 271, 272, 273.

Robinson, Richard, 187.

Runnels, the, 202.

Russel, John, 2 I3, $225,227$.

Russells, the, see Bedford, dukes of.

Sallows, 206.

Salman, widow, $26_{5}$.

Sames, in Cottenham, Manor of, I77, I94, I97, I99, 201, 203, 205, 208.

Sandis, Sir Miles, I 84, 253, 254, $255,256,257,258,259,263,27$ I. Securities, for rents, 224, 225, 226.

Severals, the, 202.

Severalty, farming in, 174 . 
Scott, Richard, I97, 200.

Sheds, 204.

Sheep, 216, 219, 23I, 232, 233, 235, $246,247,248,250,251,253,254$, $257,286$.

Sheep-cot, 175 .

Sheep-farming, I 74, I 77.

Sheep-Walk, a, 25I.

Sheirbrooke, Richard, 265.

Shepherds, 237.

Shocking, of Corn, 267, 270.

Slate, bed of, $238,239$.

Sluices, 284.

Smith, Thomas, 225.

Snowte Ditch, 259.

Soham, i76.

Sparke, Dr., rector, 182.

Stakes, 207, 23I.

Stallocke, 259, $26 \mathrm{I}$.

Standly, Peter, I 85 .

Steers, herbage of, 288.

Steward, Mark, 185.

Stint, to, 257.

Stone Ditch, 200.

Stone-hill, 205.

Stoppinges, 232.

Stretham, Church, 286.

- , Common, 265, 266.

Streetham, Fen Reeves, I82n.

Stretham, the Green in, 276.

- , rector of, 262, 269, 270.

Streets, in towns, 221.

Swine, 219, 220, 230, 246, 247, $248,25 \mathrm{I}, 285,286$.

Taylor, James, 26I, 263, 264.

Teame, 239.

Telnie, Robert, 189.

Tenants, copyhold, 208, 209, 2 ro, and passim.

Tenements, 202, 206, 207, 210, $2 \mathrm{II}$,
$213,223,226,227,228,238,240$, $24 \mathrm{I}, 243,253,255,256,257$.

Thetford, I 82, I $84,255,256$.

Thetford, Chapelry of, 189 .

Thetford Manor House, 263.

Thistles, on Common, 238.

Thistly Hill, 202.

Tillage, 173, I77, 180, 181,184 , I 89, $262,288$.

Tithes, I $80,182,184,189,214,215$, $246-252,288,289$.

Topymoor, 215, $216,217,220,242$.

Townsend, Jer., ferryman, 258.

Townson, William, 280.

Trades : Butchery, 234.

Turner, the widow, 204.

Turves, 24I.

Tyndall, Francis, I 84, I85.

Undertakers, the, 182 .

Undertakers' Piece, 237.

Walls, 265.

Ward, Dr., rector, 182.

Waterbeach, $176,185, \mathrm{x} 85^{\mathrm{n}}$.

Webb, Robert, 266.

Weir Pool, I 79, I 80.

Wells, George, 266.

West wicke, 232, 243.

Westwick, Manor of, 202.

Wheat, 253 .

Willingham, $176,182 \mathrm{n}, 184,185$, I 86.

Willows, 206, 23I, 239.

Wisbeach Barton, I90.

Wood, 206, 207, 208, 25I, 255.

Wool, 246, 247, 248, 250.

Woolfes pasture, I 79 .

Wright, John, 244.

Wronglane's End, 2 I 8.

Wyles, Mr., of Denney Abbey, 187 .

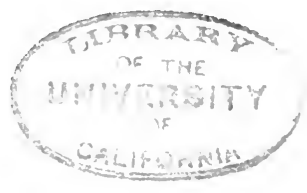




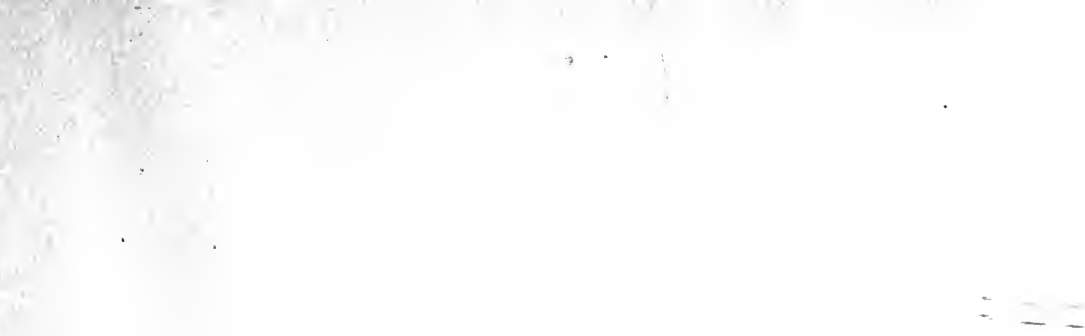




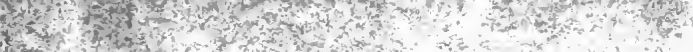

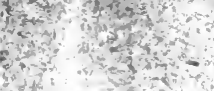

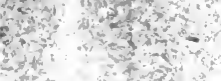

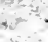
Hof 
T:

RETURN TO DESK FROM WHICH BORROWED

\section{LOAN DEPT.}

This book is due on the last date stamped below, or on the date to which renewed. Renewals only: Tel. No. 642.3405

Renewals may be made 4 days prior to date due. Renewed books are subject to immediate recall.

\section{REC'D LD FEB 15 '72
OCT 121974 虾 1}

REC'D CIRC DEPT APK 16'?'AL

JUN 13197438

PEC'D CIRC DEPT JUN $10^{\prime} 74$

AUG $211976 \quad X$

\section{IN STACKS}

FEB 211976

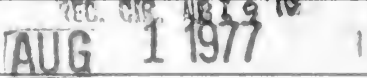

REC CIR M 15 '77

JUN 719 REC.CIR JUN1 7 BO

LD21A-40m-8;7

(P6572s10) 476-A-32

General Library

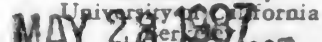

REC.MOFFI RiAP 3 ag?

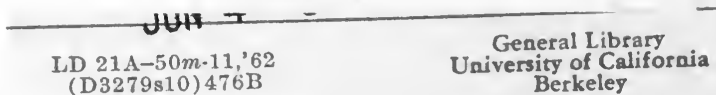




\section{FEB 211976}

LD9-30m-3,'74(R6900s4) 4185-C-107

16

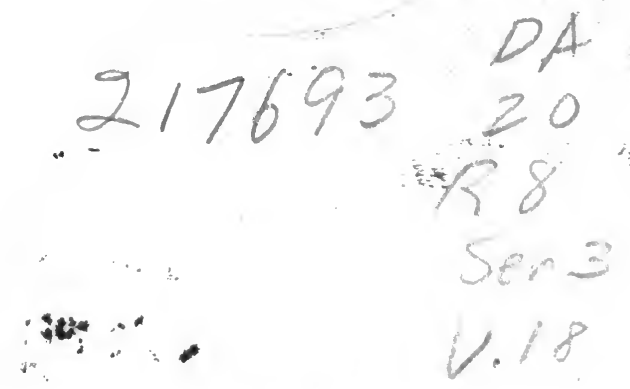

THE UNIVERSITY OF CALIFORNIA LIBRARY

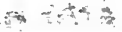

\section{U.C. BERKELEY LIBRARIES

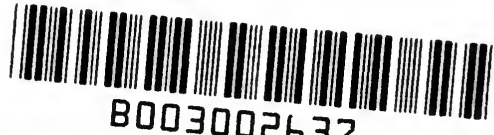 \\ 8003002637}


